\title{
The Nitrogen Budget of Earth
}

\author{
Ben Johnson ${ }^{\mathrm{a}, *}$, Colin Goldblatt ${ }^{\mathrm{a}}$ \\ ${ }^{a}$ University of Victoria, Department of Earth and Ocean Sciences, 3800 Finnerty Road, Victoria, BC V8P 5C2, Canada
}

\begin{abstract}
We comprehensively compile and review $\mathrm{N}$ content in geologic materials to calculate a new $\mathrm{N}$ budget for Earth. Using analyses of rocks and minerals in conjunction with N-Ar geochemistry demonstrates that the Bulk Silicate Earth (BSE) contains $\sim 7 \pm 4$ times present atmospheric N $\left(4 \times 10^{18} \mathrm{~kg} \mathrm{~N}\right.$, or PAN), with $27 \pm 16 \times 10^{18} \mathrm{~kg} \mathrm{~N}$. Comparison to chondritic composition, after subtracting N sequestered into the core, yields a consistent result, with BSE N between $17 \pm 13 \times 10^{18} \mathrm{~kg}$ to $31 \pm 24 \times 10^{18} \mathrm{~kg}$ N. Embedded in the chondritic comparison we calculate a N mass in Earth's core $\left(180 \pm 110\right.$ to $\left.300 \pm 180 \times 10^{18} \mathrm{~kg}\right)$ as well as present discussion of the Moon as a proxy for the early mantle.

Significantly, our study indicates the majority of the planetary budget of $\mathrm{N}$ is in the solid Earth. We suggest that the $\mathrm{N}$ estimate here precludes the need for a "missing N" reservoir. Nitrogen-Ar systematics in mantle rocks and primary melts identify the presence of two mantle reservoirs: MORB-source like (MSL) and high-N. High-N mantle is composed of young, N-rich material subducted from the surface and identified in OIB and some xenoliths. In contrast, MSL appears to be made of old material, though a component of subducted material is evident in this reservoir as well.

Taking into account $\mathrm{N}$ mass and isotopic character of the atmosphere and BSE, we calculate a $\delta^{15} \mathrm{~N}$ value of $\sim 2 \%$. This value should be used when discussing bulk Earth $\mathrm{N}$ isotope evolution. Additionally, our work indicates that all surface $\mathrm{N}$ could pass through the mantle over Earth history, and in fact the mantle may act as a long-term sink for N. Since N acts as a tracer of exchange between the atmosphere, oceans, and mantle over time, clarifying its distribution in the Earth is critical for evolutionary models concerned with Earth system evolution. We suggest that $\mathrm{N}$ be viewed in the same light as carbon: it has a fast, biologically mediated cycle which connects it to a slow, tectonically-controlled geologic cycle.
\end{abstract}

Keywords: Nitrogen, Earth, geochemistry, isotopes, chondrite, core

2010 MSC: 00-01, 99-00

\section{Introduction}

Nitrogen, the fifth most common element in the solar system, is the main component of the atmosphere, is a key nutrient for life, and has potential to be a tracer of processes linking the surface Earth to different

\footnotetext{
* Corresponding author

Email addresses: bwjohnso@uvic.ca (Ben Johnson), czg@uvic.ca (Colin Goldblatt)
} 
reservoirs in the solid planet. Though $\mathrm{N}$ has long been known to exist geologically in fluid inclusions or as $\mathrm{NH}_{4}^{+}$in mineral lattices (e.g., Mayne, 1957), it was thought to predominantly reside in the atmosphere and biosphere (Baur and Wlotzka, 1969). It is now clear that N can indeed become incorporated into minerals and rocks in significant amounts and cycles over long time scales through the atmosphere, oceans, crust, and mantle. While the absolute concentration of $\mathrm{N}$ in rocks is low (often $\sim 1 \mathrm{ppm}$, but up to $\sim 100$ or $1000 \mathrm{ppm}$ ), the great mass of the solid Earth compared to the atmosphere means that it has the potential to sequester large amounts of N. A picture of the behaviour of N in the Bulk Silicate Earth (BSE) has begun to emerge, but necessitates a new review and synthesis of available data (Fig. 1).

Similar to C (e.g., Holland, 1984), N is cycled in the Earth system in two ways: a fast, biologic cycle; and a slow, geologic cycle. Descriptions of biologic (e.g., Kelly, 2000) and geologic (e.g., Boyd, 2001, Holloway and Dahlgren, 2002, Kerrich et al. 2006) N cycles exist, but no adequate Earth system-wide picture of the fast and slow $\mathrm{N}$ cycles together is currently available. Briefly, the biologic cycle (for the modern Earth) is as follows: $\mathrm{N}_{2}$ in the atmosphere dissolves in the ocean and is converted to a biologically available form by N-fixing bacteria. This process is termed N-fixation. Nitrogen-fixing bacteria are either consumed by other organisms, or release $\mathrm{N}$ in waste, primarily as $\mathrm{NH}_{4}^{+}$, which is quickly oxidized to $\mathrm{NO}_{3}^{-}$in a bacteriallymediated process called nitrification. The primary return flux of $\mathrm{N}$ to the atmosphere is via denitrification, where $\mathrm{NO}_{3}^{-}$is used by certain bacteria as the terminal acceptor in the electron transport chain and converted to either $\mathrm{N}_{2}$ or $\mathrm{N}_{2} \mathrm{O}$. Recently, the importance of an additional reaction, anaerobic ammonium oxidation or anammox has been recognized as a return flux of $\mathrm{N}$ to the atmosphere. (Thamdrup, 2012, and references therein). This is another bacterially mediated process whereby $\mathrm{NH}_{4}^{+}$reacts with $\mathrm{NO}_{2}^{-}$to produce $\mathrm{N}_{2}$ and two $\mathrm{H}_{2} \mathrm{O}$ molecules.

The slow geologic cycle begins when dead organic matter sinks and settles in oceanic sediment. Organic $\mathrm{N}$ breaks down in the sediment via hydrolysis reactions, and converts to $\mathrm{NH}_{4}^{+}$Hall, 1999). Since $\mathrm{NH}_{4}^{+}$has the same charge and a similar ionic radius as $\mathrm{K}^{+}$, it substitutes into mineral lattice sites that are normally occupied by $\mathrm{K}^{+}$. Clay minerals, micas, and K-feldspars are important mineral hosts of N. Once entrained in oceanic sediments and crust, $\mathrm{N}$ is carried into subduction zones, where it is either volatilized and removed from the down-going plate or carried into the mantle past the subduction barrier. In general, subduction zones with high geothermal gradients favour volatilization (e.g., Elkins et al., 2006), while cooler subduction zones favour $\mathrm{N}$ retention (e.g., Mitchell et al., 2010). Volatilized $\mathrm{N}$ either oxidizes to $\mathrm{N}_{2}$ and escapes via arc volcanism or is incorporated into intrusive igneous rocks. Nitrogen that is not returned to the surface becomes entrained in mantle circulation. Basalts at both mid-ocean ridges (MORB) (Marty, 1995) and ocean islands (OIB) (Mohapatra et al. 2009) show evidence for this surface-derived N, through either positive $\delta^{15} \mathrm{~N}$ values ${ }^{1}$ (OIB) or correlation with radiogenic Ar (Sec. 4.1).

\footnotetext{
${ }^{1}$ Stable isotope notations are in per mil (\%o) notation, where

$$
\delta^{X} \mathrm{E}(\% 0)=\left(\frac{{ }^{X} \mathrm{E} /{ }^{x} \mathrm{E}_{\text {sample }}}{{ }^{X} \mathrm{E} /{ }^{x} \mathrm{E}_{\text {standard }}}-1\right) * 1000
$$
}




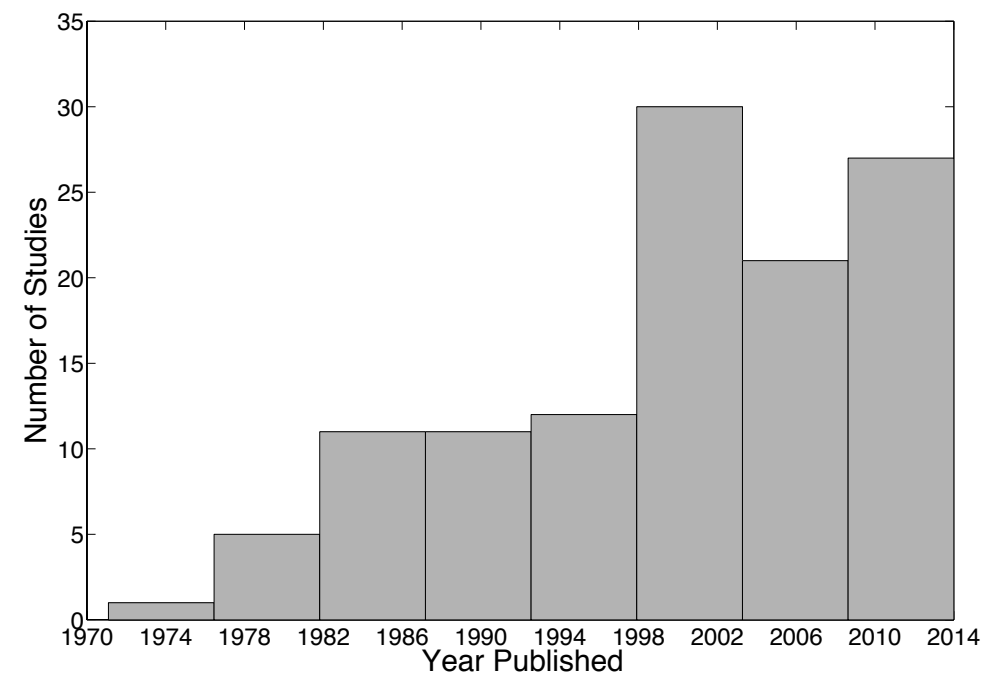

Figure 1: Number of studies measuring $\mathrm{N}$ in geologic materials since 1975. The number of studies has increased as detection capability improves. Data produced after the mid 1990s have not been incorporated into a broad, Earth system perspective on the $\mathrm{N}$ cycle.

While the general outline of the geologic $\mathrm{N}$ cycle is known, in order to more fully quantify this cycle and describe changes in it over Earth history, we calculate a thorough inventory of the $\mathrm{N}$ on Earth. This is a necessary step to accurately portray the Earth-system nature of the $\mathrm{N}$ cycle. To achieve this goal we present two approaches: a "top-down" and "bottom-up" budget estimates. The "top-down" approach uses the composition of planetary building blocks and analogues to bracket total Earth $\mathrm{N}$ content. We then subtract the amount of $\mathrm{N}$ in the core to estimate BSE N content. For the "bottom-up" approach, we compile analyses of $\mathrm{N}$ in terrestrial rocks and minerals. We use these to estimate $\mathrm{N}$ concentration in various reservoirs: oceanic and continental sediments, oceanic and continental crust, and the mantle. We also use observed relationships between $\mathrm{N}$ and $\mathrm{Ar}$ from basalts to estimate the mantle $\mathrm{N}$ content. In addition, we briefly discuss the behaviour of $\mathrm{N}$ in specific reservoirs. Our approach differs from past attempts by utilizing an extensive literature compilation in conjunction with new experimental results to provide a thorough, comprehensive assessment of the $\mathrm{N}$ in all reservoirs of the Earth.

The structure of the paper is to first present description of the speciation and behaviour of $\mathrm{N}$ in the solid Earth, then a brief discussion of the data compilation used herein; this is followed by the two budget approaches, and finally a discussion of the implications of results. We present a discussion of $\mathrm{N}$ speciation and solubility first to serve as orientation, as $\mathrm{N}$ can exist as different species in the Earth depending on physical and chemical conditions. A flurry of recent experiments have elucidated many aspects of $\mathrm{N}$ solubility in silicate minerals (e.g., Li et al., 2013), metal alloys (Roskosz et al., 2013), and fluids (Li and Keppler, 2014).

$\mathrm{E}$ is element of interest, $X$ is heavy isotope, $x$ is light isotope. $\delta^{13} \mathrm{C}$ standard is $\mathrm{V}-\mathrm{PDB}$ and the $\delta^{15} \mathrm{~N}$ standard is $\mathrm{N}_{2}$ in air, which have a $\delta^{13} \mathrm{C}$ or $\delta^{15} \mathrm{~N}$ value of $0 \%$ by definition. 
Table 1: Previous estimates for the $\mathrm{N}$ budget of the silicate Earth. There is significant disagreement between estimates, necessitating a more comprehensive approach. All values are $10^{18} \mathrm{~kg} \mathrm{~N}$

\begin{tabular}{|c|c|c|}
\hline Reservoir & Amount & Reference \\
\hline BSE & 2.78 & Halliday (2013) \\
\hline \multirow[t]{2}{*}{ Mantle } & 5 & Marty (2012) \\
\hline & $\geq 8.4 \pm 5.2$ & Goldblatt et al. (2009) \\
\hline \multirow[t]{4}{*}{ Continental Crust } & $2.1 \pm 1.1$ & Goldblatt et al. (2009) \\
\hline & 1.1 & Rudnick and Gao (2003 2014) \\
\hline & 1.3 & Wedepohl (1995) \\
\hline & 14 & Delwiche 1970$)$ \\
\hline Continental Sediments & 4 & Delwiche (1970) \\
\hline
\end{tabular}

Ultimately, we find that both approaches are mutually consistent. Chondritic comparison suggests between $17 \pm 13 \times 10^{18} \mathrm{~kg}$ to $31 \pm 24 \times 10^{18} \mathrm{~kg} \mathrm{~N}$ in the BSE ; terrestrial compilation suggests $27 \pm 16 \times 10^{18}$ $\mathrm{kg} \mathrm{N}$ in the BSE. Our work indicates not only suggests a higher $\mathrm{N}$ mass in the BSE than previous work (Goldblatt et al. 2009), it arrives at approximately the same value from two independent tactics. A higher $\mathrm{N}$ content may have important implications for the geochemical history of $\mathrm{N}$ on the Earth. In addition, our budget allows for a reassessment of the overall $\mathrm{N}$-isotopic composition of the planet, which is used to track interaction between various reservoirs on the Earth. These implications are detailed in our discussion (Sec 5.

\section{Nitrogen speciation in geologic materials, experimental results, and budget tools}

In this section, we first summarize which $\mathrm{N}$ species are found in geologic materials, highlighting silicate rocks and minerals, fluids, and Fe-metal. Secondly, we incorporate recent experimental work to attempt to quantitatively describe $\mathrm{N}$ behaviour in geologic materials in response to changes in pressure, temperature, and oxygen fugacity. Thirdly, we describe the database used for subsequent budget calculation. Details pertinent to specific reservoirs will be discussed in the appropriate sections.

\subsection{Nitrogen speciation in the solid Earth}

Nitrogen is present as a number of species in the solid Earth. The primary control on speciation is redox, with temperature, pressure, and even $\mathrm{pH}$ playing roles in stability and solubility. Oxygen fugacity $\left(f_{\mathrm{O}_{2}}\right)$ is presented relative to some mineralogically controlled buffer (Frost, 1991). Buffers used in this study, in order 
of decreasing $f_{\mathrm{O}_{2}}$, are Nickel-Nickel Oxide (NiNiO), Fayalite-Magnetite-Quartz (FMQ), and Iron-Wüstite (IW). Important $\mathrm{N}$ species in the solid Earth are, in order of decreasing oxidation state, $\mathrm{N}_{2}$ (fluid inclusions and degassing magmas) (e.g., Marty, 1995), $\mathrm{NH}_{3}$ (in reduced fluids) (Li and Keppler, 2014), $\mathrm{NH}_{4}^{+}$(stably bound in mineral lattices) (e.g., Itihara and Honma, 1979), and nitrides (e.g., FeN) (e.g., Adler and Williams, 2005). Small differences in $\mathrm{pH}$ (Mikhail and Sverjensky, 2014), especially in the mantle, may also exert some control over $\mathrm{N}$ speciation, though this is likely secondary when compared with $f_{\mathrm{O}_{2}}$.

There are three important reservoirs that contain the various species of $\mathrm{N}$ : silicate rocks and minerals, fluids and magmas, and Fe-metal. In general, $\mathrm{N}$ in silicate rocks and minerals is found in reduced forms, as either organic material or, more importantly for stable geologic incorporation, as $\mathrm{NH}_{4}^{+}$. While there are examples of $\mathrm{N}$-silicates (e.g., buddingtonite $\left(\mathrm{NH}_{4} \mathrm{AlSi}_{3} \mathrm{O}_{8}\right)$ and tobelite $\left.\left(\left(\mathrm{NH}_{4} \mathrm{~K}\right) \mathrm{Al}_{2}\left(\mathrm{Si}_{3} \mathrm{Al}\right) \mathrm{O}_{8}(\mathrm{OH})_{2}\right)\right)$, a much more important path for $\mathrm{N}$ incorporation into minerals is the substitution of trace amounts of $\mathrm{NH}_{4}^{+}$; this mechanism is the most geologically stable way for $\mathrm{N}$ to be found in minerals and rocks. Ammonium has, depending on coordination, an ionic radius that is $<0.2 \AA$ larger than the ionic radius of $\mathrm{K}^{+}(1.61-1.69$ vs. 1.46-1.63), and can readily substitute into K-bearing minerals (Whittaker and Muntus, 1970, Khan and Baur, 1972) or for $\mathrm{Na}$ and $\mathrm{Ca}$ in plagioclase feldspars (Honma and Itihara, 1981). Indeed, $\mathrm{K}$ and $\mathrm{N}$ concentrations are correlated in sedimentary (especially metasedimentary) rocks, though this relationship is less clear in other rock types (e.g., Busigny et al. 2005b). The source of the $\mathrm{NH}_{4}^{+}$can either be dead organic matter, which breaks down into amino acids and is subsequently hydrolized during burial, or some previous inorganic source (Hall, 1999). In general, $\mathrm{N}$ concentrations decrease with increasing metamorphic grade (e.g., Haendel et al., 1986, Bebout and Fogel, 1992), though the $\mathrm{NH}_{4}^{+}$-Si bond can be quite resilient during metamorphism (e.g., Pitcairn et al., 2005, Palya et al., 2011). It is also possible for $\mathrm{N}$ to be found as $\mathrm{N}^{3-}$ (Libourel et al. 2003), which can substitute for $\mathrm{O}^{2-}$ in silicate lattices or bond with metals Roskosz et al. 2013).

In contrast with silicate rocks and minerals, most fluids and magmas originating from the crust or upper mantle are oxidizing, with an $f_{\mathrm{O}_{2}}$ near the (FMQ) buffer. At fugacity near FMQ, both natural samples (e.g., Marty, 1995: Nishizawa et al., 2007) and experimental results (e.g., Libourel et al. 2003, Li and Keppler, 2014) show that $\mathrm{N}_{2}$ is the dominant $\mathrm{N}$ species in magmas and fluids. At more reduced $\left(f_{\mathrm{O}_{2}}<\mathrm{FMQ}\right.$ ) conditions, $\mathrm{NH}_{3}$ becomes stable in fluids, and may even dominate in some crustal and upper mantle conditions (Li and Keppler, 2014).

The third important reservoir for $\mathrm{N}$ is Fe-metal. Nitrogen is quite soluble in Fe-metal alloys at a variety of depths in the Earth (Kadik et al., 2011, Roskosz et al., 2013). It likely either dissolves as $\mathrm{NH}_{3}$ or forms Fe-N (nitride) compounds. This has important ramifications for the $\mathrm{N}$ distribution in the Earth. Not only could significant $\mathrm{N}$ be found in Earth's core, Fe-Ni metal may be present in the mantle transition zone and lower mantle (Frost and McCammon, 2008). There might be $\leq 10 \mathrm{wt} . \% \mathrm{~N}$ in FeNi-metal and $\leq 0.5 \mathrm{wt} . \% \mathrm{~N}$ in silicates in the transition zone and lower mantle (Roskosz et al. 2013). These concentrations indicate that an enormous quantity of $\mathrm{N}$ are theoretically plausible in the deeper domains of the mantle. This is discussed 
in more detail later.

Since $\mathrm{N}$ concentrations in geologic materials are usually quite low, analytical techniques present a nontrivial obstacle. A thorough discussion on this subject is provided by both Holloway and Dahlgren (2002) and Bräuer and Hahne (2005). Briefly, N can be measured by dissolution/combustion and analysis on a mass spectrometer, spectral methods, Kjeldahl extraction, or colorimetric methods. These techniques continue to evolve and improve (Yokochi and Marty, 2006; Barry et al., 2012), and the availability of quality N data from rocks will continue to grow.

\subsection{Experimental results}

We have compiled experimental results to augment the discussion in the previous section and to quantitatively describe the $\mathrm{N}$ solubility of geologic materials (Figs. 22 3). Measurements have been made for $\mathrm{N}$ in minerals (Li et al., 2013), silicate melt (Libourel et al., 2003, Mysen et al., 2008, Mysen and Fogel, 2010, Mysen et al. 2014), Fe-metal (Kadik et al., 2011, Roskosz et al., 2013), and aqueous fluids (Li and Keppler. 2014: Li et al., 2015). Experimental conditions are variable (e.g., different starting materials, presence of alkalis, etc.), so at times trends are only visible when discussing single studies. Most studies use a basaltic composition for silicate components, with one using a more felsic, haplogranite material (Li et al. 2015). In spite of these differences, however, general observations can be made from these data. Importantly, results allow for calculation of $\mathrm{N}$ capacity and/or contents in poorly or unsampled reservoirs in the Earth, such as the core (Sec. 3.2) and parts of the mantle (Sec. 4.5.2).

Pressure, temperature, and $f_{\mathrm{O}_{2}}$ all have an effect on $\mathrm{N}$ solubility in silicate melts, Fe-metal, and aqueous fluids. A first order observation is that $\mathrm{N}$ concentration appears to always be higher in fluids, melts, and Femetal than in coexisting silicate minerals (Fig. 2). This is especially clear when the distribution coefficients $\left(\mathrm{D}_{\text {metal} / \text { fluid }}=\left[\mathrm{N}_{\text {metal } / \text { fluid }}\right] /\left[\mathrm{N}_{\text {silicate }}\right]\right)$ are calculated (Fig. 3. At all measured conditions, $\mathrm{N}$ prefers metal or fluid over silicates.

Increasing pressure has noticeable effects on $\mathrm{N}$ solubility in silicates and metals, while the effect is less clear in fluids. Silicate N concentration increases with pressure, and, at least in the presence of Fe-metal, saturates at 0.64 wt.\% at pressures above about 5 GPa (Roskosz et al. 2013). At lower pressures, solubility appears to follow a Henry's law relationship, given by:

$$
[\mathrm{N}]_{\mathrm{S}}=k_{H} \mathrm{p}
$$

where $[\mathrm{N}]_{\mathrm{S}}$ is in wt.\%, $k_{H}$ is $0.128 \mathrm{wt} . \% \mathrm{GPa}^{-1}$, and $\mathrm{p}$ is pressure (GPa). Concentration in Fe-metal also increases with pressure, and appears to be described by a Sievert's law equation:

$$
[\mathrm{N}]_{\mathrm{M}}=k_{s} \sqrt{\mathrm{p}}
$$

where $[\mathrm{N}]_{\mathrm{M}}$ is in wt.\%, $k_{s}$ is an experimentally determined constant $\left(3.06 \mathrm{wt} . \% \mathrm{GPa}^{-1 / 2}\right)$, and $\mathrm{p}$ is pressure (GPa). The pressure effect in aqueous fluids appears to be equivalent to silicates and metal, but experiments have been done only at lower pressures (Li et al. 2015). 
Increasing temperature results in a decrease in $\mathrm{N}$ content in silicate melts (Fig. 2). The effect is most clearly seen in data from individual studies (Libourel et al., 2003; Mysen et al. 2008). Higher temperatures favour formation of $\mathrm{N}_{2}$, which is more easily removed from silicate melts via extraction in fluids. Figure 3 shows this well: higher temperature is associated with a higher $\mathrm{D}_{\text {fluid }}$. This is partially due to the instability of $\mathrm{N}-\mathrm{H}$ bonds at high temperature. Experiments done at the highest temperatures have Fe-metal in equilibrium with silicates, and since $\mathrm{N}$-solubility in metal increases with increasing temperature, it is likely that $\mathrm{N}$ was lost from the silicates and taken up by the Fe-metal in these experiments (Roskosz et al., 2013).

In contrast, $f_{\mathrm{O}_{2}}$ has a fairly strong effect on $\mathrm{N}$ solubility, and especially $\mathrm{N}$ partitioning between silicates and fluids (Fig. 3). In each experiment shown here, decreasing $f_{\mathrm{O}_{2}}$ results in higher $\mathrm{N}$ content in silicates. This effect is less clear in metal, though these experiments were carried out at a narrower $f_{\mathrm{O}_{2}}$ range, and $f_{\mathrm{O}_{2}}$ must be at or below the IW buffer $(=\Delta \mathrm{NNO}-4)$ to even have Fe-metal stable in the experiment. Since oxidizing conditions promote $\mathrm{N}$ speciation as more fluid-mobile $\mathrm{N}_{2}$, as opposed to $\mathrm{NH}_{4}^{+}$, $\mathrm{D}_{\text {fluid }}$ tends to decrease with decreasing $f_{\mathrm{O}_{2}}$ as well. While the magnitude of the $f_{\mathrm{O}_{2}}$ effect is different between different studies, the direction is the same throughout: lower $f_{\mathrm{O} 2}$ results in higher $\mathrm{N}$ contents in silicates.

There are also some measurements of N-contents in minerals directly. We utilize equations, described by Li et al. (2013), of $\mathrm{N}$ solubility experimental results for olivine, pyroxene, and melt (in the absence of Fe-metal) to guide both estimates of $\mathrm{N}$ concentration and distribution coefficients (described below) between minerals and melt in poorly sampled reservoirs:

$$
\begin{gathered}
\text { Olivine }: \log _{10}[\mathrm{~N}]=2.15-\frac{6.8 \times 10^{3}}{\mathrm{~T}}+0.27 \mathrm{P}-0.43 \Delta \mathrm{NiNiO} ; \mathrm{r}^{2}=0.79 \\
\text { Pyroxene }: \log _{10}[\mathrm{~N}]=6.48-\frac{8.7 \times 10^{3}}{\mathrm{~T}}+0.086 \mathrm{P}-0.122 \Delta \mathrm{NiNiO} ; \mathrm{r}^{2}=0.64 \\
\text { Melt }: \log _{10}[\mathrm{~N}]=0.92-\frac{3.50 \times 10^{3}}{\mathrm{~T}}+0.4 \mathrm{P}-0.083 \Delta \mathrm{IW} ; \mathrm{r}^{2}=0.70
\end{gathered}
$$

The above equations have temperature $(\mathrm{T})$ in $\mathrm{K}$, pressure $(\mathrm{P})$ in $\mathrm{GPa}, \Delta \mathrm{NiNiO}$ or $\Delta \mathrm{IW}$ is the $f_{\mathrm{O}_{2}}$ relative to the $\mathrm{NiNiO}$ or IW buffer, and $[\mathrm{N}]$ is in ppm. At appropriate conditions, concentrations of up to $100 \mathrm{ppm}$ may be possible in the lowermost upper mantle (Li et al. 2013), which means the upper mantle may have the capacity to sequester $\sim 80 \times 10^{18}-200 \times 10^{18} \mathrm{~kg} \mathrm{~N}$, which is $20-50$ times PAN.

The last tool based on experiments we utilize is measured or inferred partition coefficients $\left(\mathrm{K}_{\mathrm{D}}=[\text { Element }]_{\text {mineral }} /[\text { Element }]_{\text {melt }}\right)$; these are often used in conjunction with an equation linking partition coefficients to degree of partial melting (Rollinson, 1993).

$$
\frac{\left[\mathrm{C}_{\mathrm{L}}\right]}{\left[\mathrm{C}_{\mathrm{o}}\right]}=\frac{1}{\mathrm{~K}_{\mathrm{D}}+\mathrm{F}\left(1-\mathrm{K}_{\mathrm{D}}\right)}
$$

$\left[\mathrm{C}_{\mathrm{o}}\right]$ is element concentration in source and $\left[\mathrm{C}_{\mathrm{L}}\right]$ is concentration in melt, and $\mathrm{F}$ is degree of partial melting. Note that this equation is for batch (equilibrium) melting, which means that melt formed equilibrates with residual solids. We assume that any melt much reach a critical threshold $(\sim 1-10 \%)$ before extraction from the source rock, and prior to extraction it would have time to equilibrate fully with residual solids. 


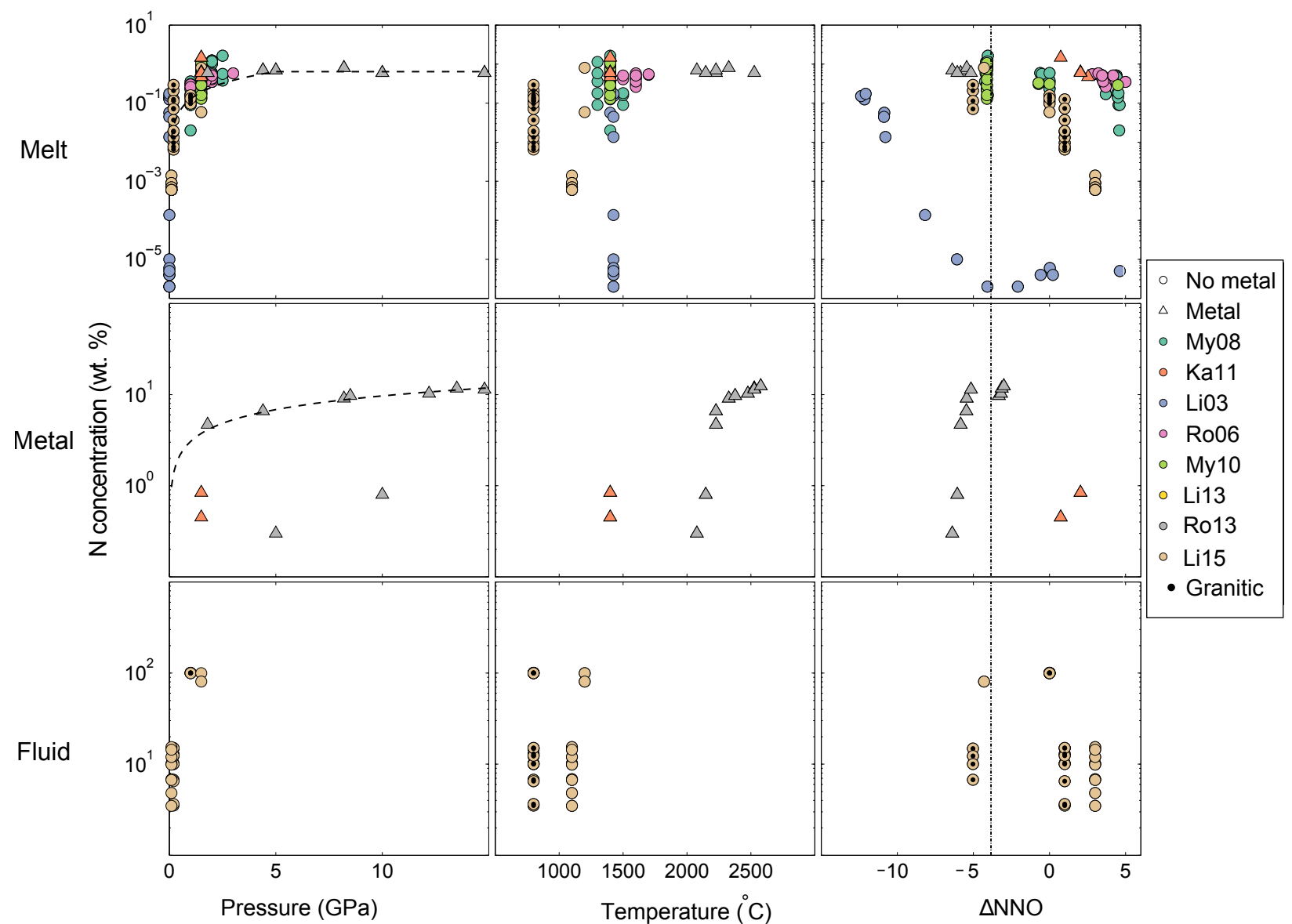

Figure 2: Compilation of recent experiments measuring $\mathrm{N}$ solubility in silicate melts, Fe-metal, and aqueous fluids. Experiments that have silicate and Fe-metal in equilibrium $(\Delta)$ and those with no metal (o) are shown. Note log scale for $\mathrm{N}$ concentration. Different colours refer to specific studies: My08 (Mysen et al. 2008), Ka11 (Kadik et al. 2011), LI03 (Libourel et al. 2003), Ro06 (Roskosz et al. 2006), My10 (Mysen and Fogel, 2010), Li13 (Li et al. 2013), Ro13 (Roskosz et al. 2013), and Li15 (Li et al. 2015). All experimental runs used basaltic composition, aside from the few marked "Granitic". We show concentrations as a function of pressure, temperature, and $f_{\mathrm{O}_{2}}$ (relative to the NiNiO buffer) for all three phases. Dashed lines are empirical fits to data, shown in the text (Eq. 2.3). Vertical dashed line in $\Delta$ NNO plots represent the IW buffer $(\Delta N N O-4)$, below which Fe-metal is stable. While $f_{\mathrm{O}_{2}}$ is the primary control on $\mathrm{N}$ speciation, pressure appears to be very important in solubility. 


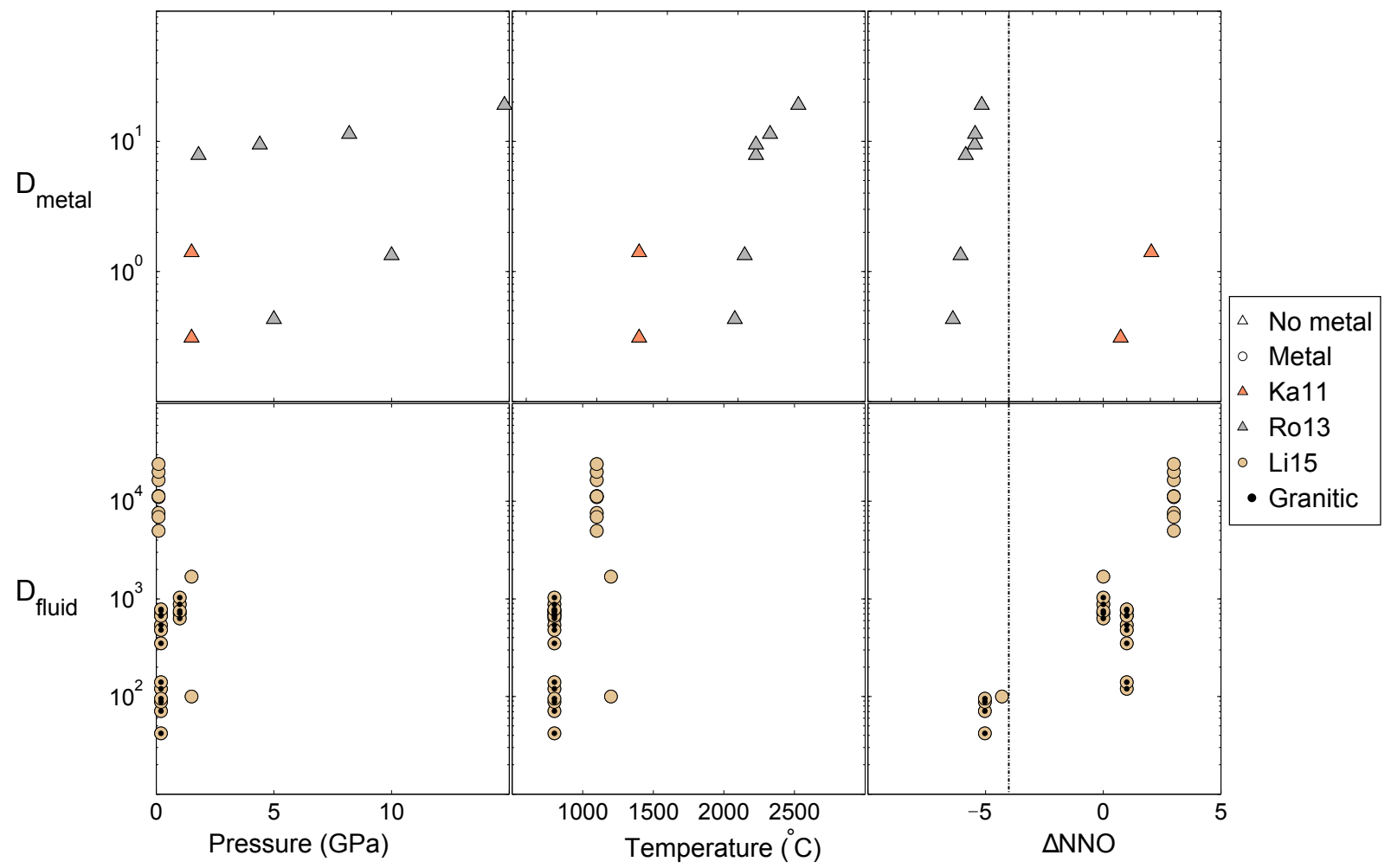

Figure 3: Distribution coefficients for metal:silicate melt (top row) and fluid:silicate melt (bottom row) as a function of temperature, pressure, and $f_{\mathrm{O}_{2}}$ (relative to the $\mathrm{NiNiO}$ buffer). Increasing pressure and temperature increases $\mathrm{D}_{\text {metal }}$. Increasing pressure decreases $\mathrm{D}_{\text {fluid }}$, and temperature seems to have a negligible effect. As $f_{\mathrm{O}_{2}}$ increases, $\mathrm{N}$ solubility in fluids increases, likely because $\mathrm{N}$ is present as $\mathrm{N}_{2}$. References and symbols are the same as Fig. 2 


\subsection{Database of geologic $N$ measurements}

We have compiled all of the available, published measurements of $\mathrm{N}$ concentration and $\delta^{15} \mathrm{~N}$ values of geologic materials. Where they exist, we also include in the database $\delta^{13} \mathrm{C}$, age of sample, Ar-isotope ratios and abundance, and concentrations of elements that behave similarly to $\mathrm{NH}_{4}^{+}$, including $\mathrm{K}_{2} \mathrm{O}, \mathrm{Rb}, \mathrm{Lu}$, and $\mathrm{Yb}$. The complete database is available in the supplementary material, which is organized by both rock names, as given in the original publications, and our interpreted geologic settings,

While rock names follow standard naming procedure, we also categorize data based on geologic setting. Unmetamorphosed samples are labeled as oceanic sediments (OS), oceanic lithosphere (OL), continental sediments (CS), and continental lithosphere (CL). Altered reservoirs (i.e., metamorphosed at $\mathrm{T}<300{ }^{\circ} \mathrm{C}$ ) are prefixed with 'A'; those metamorphosed at $\mathrm{T}>300{ }^{\circ} \mathrm{C}$ are prefixed with 'M'. Data for the mantle are from diamonds (D) and xenoliths (X). We also discuss mid-ocean ridge basalts (MORB) and ocean island basalts (OIB). These reservoirs will be addressed individually in following sections.

Nitrogen concentration from most reservoirs are log-normally distributed. To calculate $\mathrm{N}$ mass in a given reservoir, we will generally use the product of the log-normal mean of $\mathrm{N}$ concentration and mass of that reservoir. As sample size is often low, we calculate maximum likelihood estimator parameters $\hat{\mu}$ and $\hat{\sigma}^{2}$, which are the mean and variance of the natural log of concentration, respectively (Limpert et al., 2001).

$$
\begin{gathered}
\hat{\mu}=\frac{\sum_{i} \ln [\mathrm{N}]_{i}}{n} \\
\hat{\sigma}^{2}=\frac{\sum_{i}\left(\ln [\mathrm{N}]_{i}-\hat{\mu}\right)^{2}}{n}
\end{gathered}
$$

Where $\mathrm{n}$ is the number of samples. These parameters are then used to estimate the mean $(\mu)$ and standard deviation $(\sigma)$ of the total population:

$$
\begin{gathered}
\mu \simeq \bar{x}=e^{\hat{\mu}+\frac{\hat{\sigma}^{2}}{2}} \\
\sigma=\sqrt{\left(e^{\hat{\sigma}^{2}}-1\right) e^{2 \hat{\mu}+\hat{\sigma}^{2}}}
\end{gathered}
$$

Unless otherwise specified, all errors given are standard error of the mean:

$$
\mathrm{SE} \bar{x}=\frac{\sigma}{\sqrt{n}}
$$

\section{3. "Top-down" Budget: Accretion through Core formation}

In this section, we estimate the N budget of the BSE by comparing the Earth to other inner solar system bodies. The atmosphere of Venus hints that there is more $\mathrm{N}$ in the Earth than is found in its atmosphere alone. We bracket mass of $\mathrm{N}$ delivered to Earth during accretion by comparison to chondritic compositions. From this, we subtract $\mathrm{N}$ sequestered into the core to estimate the remainder in the BSE and atmosphere. While this model is dependent on the $\mathrm{N}$ content of accretionary material, we find that it is in reasonable 
agreement with our terrestrial-based budget, presented in Section 4 In addition, the $\mathrm{N}$ content of the Moon is calculated, as this may provide some constraints on the composition of the early, but post-core formation, mantle.

\subsection{Initial $N$ composition and planetary comparison: missing $N$ ?}

Some motivation for this study comes from comparison of the Earth to extraterrestrial bodies: meteorites and Venus. Undifferentiated meteorites are leftover remnants from the early history of the Solar System, and are often used as proxies for the bulk composition of the protoplanetary disk. Venus is thought to have had a similar initial volatile composition as the Earth (Ringwood and Anderson, 1977; Lécuyer et al., 2000. Chassefière et al. 2012). Comparison to both meteorites and Venus suggest that the Earth should have much more $\mathrm{N}$ than is found in the present atmosphere; by extension, we posit that the atmosphere is not the major $\mathrm{N}$ reservoir on Earth.

We address Venus first. The Venusian atmosphere contains $3.5 \pm 0.8 \% \mathrm{~N}_{2}$, with the remainder composed of predominately (96.5\%) $\mathrm{CO}_{2}$ von Zahn et al. 1983 . We calculate the mass of $\mathrm{N}\left(\mathrm{M}_{\mathrm{N}_{2}}\right)$ in the atmosphere by using the following equation:

$$
\mathrm{M}_{\mathrm{N}_{2}}=\frac{\mathrm{m}_{\mathrm{N}_{2}}}{\mathrm{~m}_{\mathrm{a}}} \cdot x_{\mathrm{N}_{2}} \cdot \frac{4 \pi \mathrm{r}^{2} \mathrm{p}}{\mathrm{g}}
$$

where $\mathrm{m}_{\mathrm{N}_{2}}$ and $\mathrm{m}_{\mathrm{a}}$ are molar masses of $\mathrm{N}_{2}\left(0.028 \mathrm{~kg} \mathrm{~mol}^{-1}\right)$ and Venus' atmosphere $\left(0.04344 \mathrm{~kg} \mathrm{~mol}^{-1}\right)$; $x_{\mathrm{N}_{2}}$ is the mixing ratio of $\mathrm{N}_{2}(0.035) ; \mathrm{r}$ is the radius of Venus $\left(6.052 \times 10^{6} \mathrm{~m}\right) ; \mathrm{p}$ is surface pressure $\left(9.2 \times 10^{6}\right.$ $\mathrm{Pa})$; and $\mathrm{g}$ is acceleration due to gravity $\left(8.87 \mathrm{~m} \mathrm{~s}^{-2}\right)$. The resulting $\mathrm{N}$ content of Venus' atmosphere is $11 \times 10^{18} \mathrm{~kg} \mathrm{~N}$. When normalized to planetary mass, Venus' atmosphere has 3.4 times the mass of $\mathrm{N}$ in Earth's atmosphere. Given similar initial volatile composition, Earth should have substantial N in non-atmospheric reservoirs. Curiously, the amount of $\mathrm{C}$ in the Venusian atmosphere $\left(\operatorname{as} \mathrm{CO}_{2}\right)$ is nearly identical to the amount of $\mathrm{C}$ in carbonate rocks on Earth (Taylor, 1992, Berner, 1998, Lécuyer et al., 2000). If a similar mass balance exists for $\mathrm{N}$, then a substantial amount of $\mathrm{N}$ must be in geologic reservoirs on Earth.

Whilst the exact nature and composition of planetary accretionary bodies are a matter of debate, (e.g., Marty, 2012, Halliday, 2013), some combination of chondrite-like material accreted to form the rocky planets, including Earth. The volatile content of these bodies is thought to have decreased with distance from the Sun, though the feeding zones of growing planets may be substantial (Kaid and Cowan, 2015). We bracket terrestrial $\mathrm{N}$ content by using volatile-poor enstatite chondrites (EC) and volatile-rich carbonaceous chondrites (CC) as analogs for possible volatile delivery material. Note we are not attempting to find a "perfect fit" meteorite to explain terrestrial volatiles, but simply providing some context for how much N should be present in the planet.

To utilize N contents of chondrite proxies, we follow the approach of Marty (2012) for both CC and EC. Marty compared two chondrites' (Orguiel and Murchison) volatile abundances to a calculated volatile budget for the Bulk Earth (BE). These specific meteorites were chosen as they are primitive in composition 

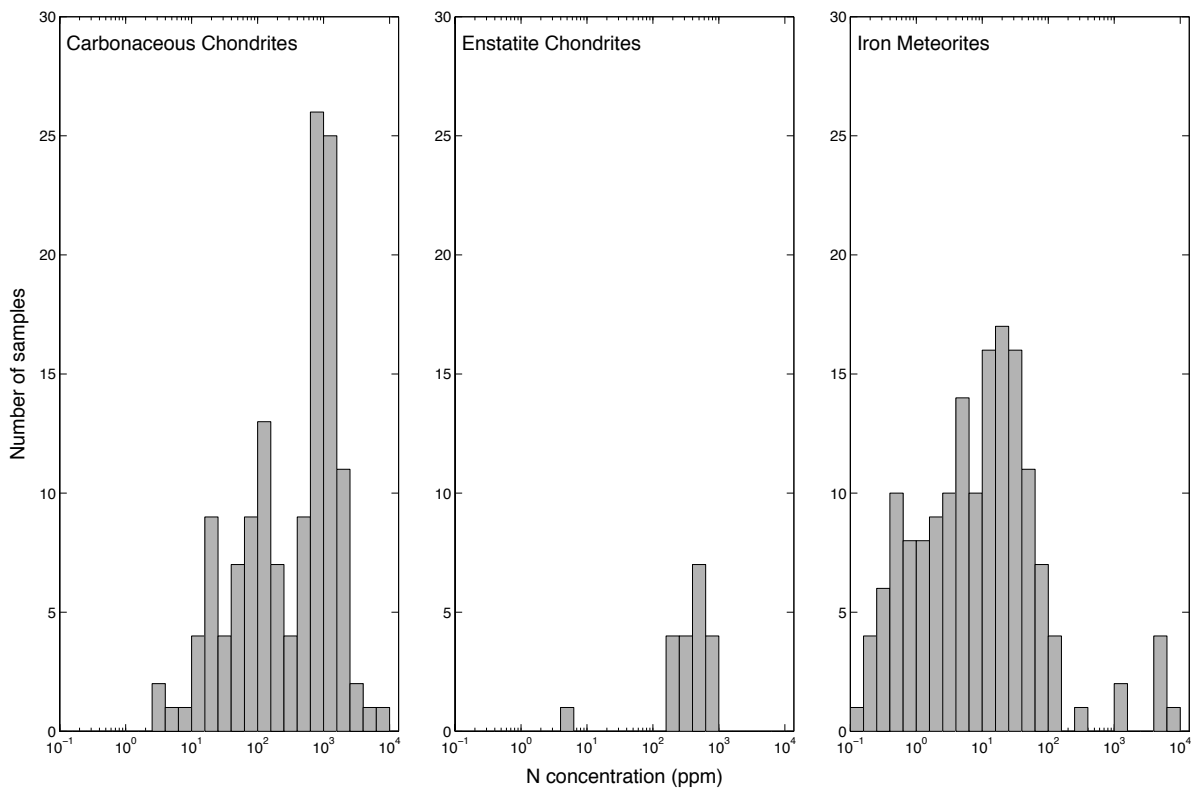

Figure 4: Nitrogen concentration in carbonaceous chondrites (CC), enstatite chondrites (EC), and iron meteorites. Nitrogen content of both CC (1235 $\pm 440 \mathrm{ppm})$ and EC (605 $\pm 2-6 \mathrm{ppm})$ are significant, and suggest many atmospheric masses of $\mathrm{N}$ were delivered to the Earth during accretion. Iron meteorites are presented as a proxy for N content of the core (140 $\pm 10 \mathrm{ppm}$, Sec. 3.2 See supplemental information for data table.

and have experienced low grades of metamorphism. We include both a broader suite of CC and EC analyses. Both chondrite types have substantial N content: EC have an average N concentration of $605 \pm 206 \mathrm{ppm}$ and CC $1235 \pm 440$ ppm (Fig. 4).

Non- $\mathrm{N}$ volatile elements (e.g., $\mathrm{C}, \mathrm{H}_{2} \mathrm{O}$, halogens) appear to be depleted in the Earth relative to chondritic concentration (Marty, 2012). These volatiles are expected to have negligible concentrations in the core, which is likely not the case for $\mathrm{N}$, as discussed in the next section. Therefore, we assume that the abundance calculated by Marty for the BSE plus atmosphere accounts for the total abundance, and differences from chondritic values are due to processes during accretion/delivery. Note that we exclude Xe from this comparison, as it is more depleted than other volatiles, and requires explanation beyond the scope of this paper (e.g., Pujol et al., 2011).

Overall, we show that the Earth appears to be depleted by about an order of magnitude compared to chondritic values (Table 2), which is consistent with Marty (2012). Using only Orguiel (CI-chondrite) and Murchison (CM-chondrite) suggests terrestrial volatiles are $2.48 \pm 0.3 \%$ as abundant as they are in CI/CMchondrites. Incorporating analyses of a broader suite of CC gives an indistinguishable volatile abundance pattern, with terrestrial volatiles $2.75 \pm 0.2 \%$ as abundant as CC. The latter is adopted here. Enstatite comparison yields less consistent results, though are within an order of magnitude $(9.2 \pm 0.1 \%)$. This value was calculated without Ne-abundance, as this appears to be distinct from other volatiles (Table 2).

If $\mathrm{N}$ behaved similarly to other volatiles during accretion/delivery, the abundance values can be used in 
concert with N concentrations of CC and EC to calculate BE N. Multiplying CC N content (1235 \pm 440 ppm) by BE/CC abundance $(2.75 \pm 0.2 \%)$ gives BE N mass of $204 \pm 75 \times 10^{18} \mathrm{~kg} \mathrm{~N}$; the same calculation with EC $\mathrm{N}$ content $(605 \pm 206 \mathrm{ppm})$ and $\mathrm{EC} / \mathrm{BE}$ abundance of $9.2 \pm 0.1 \%$ gives BE $\mathrm{N}$ mass of $330 \pm 120 \times 10^{18} \mathrm{~kg}$ N. These masses are equivalent to a BE N concentration of $34 \pm 12$ ppm and $55 \pm 20$ ppm, respectively. For comparison, both $\mathrm{N}$ mass estimates are two orders of magnitude greater than the mass of $\mathrm{N}$ in the present atmosphere $\left(4 \times 10^{18} \mathrm{~kg}\right)$.

While the preceding approach is appropriate if $\mathrm{N}$ had similar behaviour to noble gases, water, and $\mathrm{C}$ during accretion, it is possible that $\mathrm{N}$ may have existed in reduced forms in the protoplanetary disk. Ammonia in comets is well known (Oró 1961), and recent identification of $\mathrm{NH}_{3}$ as inclusions in primitive chondrites indicates that reduced $\mathrm{N}$ was also present in the chondrite-forming region of the solar system (Harries et al. 2015). If $\mathrm{N}$ was found as $\mathrm{NH}_{4}^{+}$in significant quantities in the Earth-forming region, it may have behaved more like $\mathrm{K}$ or $\mathrm{Rb}$ than noble gases. We note that $\mathrm{NH}_{3}$ was likely found mostly in ices, and its behaviour would be quite different than $\mathrm{NH}_{4}^{+}$substituting into silicate lattices or Fe-metal. The following discussion assumes $\mathrm{N}$ was found as $\mathrm{NH}_{4}^{+}$in the Earth-forming region.

Estimates of $\mathrm{BE} \mathrm{N}$ based on $\mathrm{K}$ and $\mathrm{Rb}$ content of $\mathrm{CC}$ and $\mathrm{EC}$ are higher than noble gas constraints (Table 3). EC have higher K (770 ppm) and Rb (2.5 ppm) concentrations than $\mathrm{CC}([\mathrm{K}]=400 \mathrm{ppm},[\mathrm{Rb}]=1.7$ ppm) (Wasson and Kallemeyn, 1988). The Bulk Earth (BE) has 280 ppm K (Arevalo et al., 2009) and $0.6 \mathrm{ppm} \mathrm{Rb}$ (Palme and O'Neill, 2014). These abundances suggest the Earth has about 1/3 as much K or $\mathrm{Rb}$ as chondrites. If $\mathrm{N}$ behaved like $\mathrm{K}$ or $\mathrm{Rb}$, it would have a very large mass in the $\mathrm{BE}$ of between $870-5200 \times 10^{18} \mathrm{~kg} \mathrm{~N}$ (Table 4). Since N is likely more volatile than $\mathrm{K}$ and $\mathrm{Rb}$, this provides a strict upper limit on $\mathrm{N}$ abundance in the Earth. For the remainder of the paper we adopt the CC- and EC-volatile based proxy, but do not exclude $\mathrm{N}$ behaving somewhere in between more volatile elements and $\mathrm{K}$ or $\mathrm{Rb}$ during planetary formation.

It should be noted that neither class of chondrite appear to fully satisfy the isotope composition of volatile elements on Earth. Both EC (Grady et al., 1986) and CC (Pearson et al., 2006) have $\delta^{13} \mathrm{C}$ values similar to the mantle value of $-5 \%$. A significant problem with EC as proxy for volatile delivery is that they have negligible water content, and therefore very low $\mathrm{H}$. In contrast, CC are more water-rich and have $\delta \mathrm{D}$ values are more or less consistent with at least the surface reservoirs of Earth (Marty, 2012). The $\delta^{15} \mathrm{~N}$ values of the mantle $(-35 \%$ to $-5 \%$ ) match more closely with EC, $\sim-35 \%$ (Grady et al., 1986), than with CC, which are variable, but consistently positive (Pearson et al., 2006).

\subsection{Core Formation, $N$ sequestration, and remaining BSE $N$ content}

Now that we have established some estimates for initial $\mathrm{N}$ content, the next step is to model $\mathrm{N}$ behaviour during core formation; some $\mathrm{N}$ was likely incorporated into the core. Core formation occurred as gravitational separation of $\mathrm{Fe}, \mathrm{Ni}$, and additional elements from silicates during accretion. Nitrogen is siderophile (soluble in metal-Fe) under reducing conditions, allowing large quantities of $\mathrm{N}$ to be scavenged during core formation. Because the core is geochemically isolated from the BSE (Halliday, 2004), any scavenged N is effectively 
Table 2: Estimated volatile concentrations for $\mathrm{C}, \mathrm{H}_{2} \mathrm{O}, \mathrm{Ne}$, Ar, and $\mathrm{Kr}$ in chondrites after Marty (2012), used to estimate volatile retention during accretion. Shown are concentrations in CI-CM chondrite (CI/CM), the most primitive carbonaceous chondrites, analyses from all classes of carbonaceous chondrites (CC), enstatite chondrite (EC), and bulk Earth (BE, which is BSE plus atmosphere). We do not include $\mathrm{Xe}$, which is depleted compared to chondrites and other volatiles and requires additional explanation beyond the scope of this paper. Concentrations are in $\mathrm{mol} \mathrm{g}^{-1}$, and abundances are shown in percent. References are indicated with superscripts. Errors for concentrations are $1 \sigma$. Abundance errors are shown as $\mathrm{SE}_{\bar{x}}$, with $1 \sigma$ values given in parentheses. We calculated $\mathrm{SE}_{\bar{x}}$ based on $1 \sigma$ values and number of analyses for each volatile. $\mathrm{SE}_{\bar{x}}$ are used in subsequent calculations.

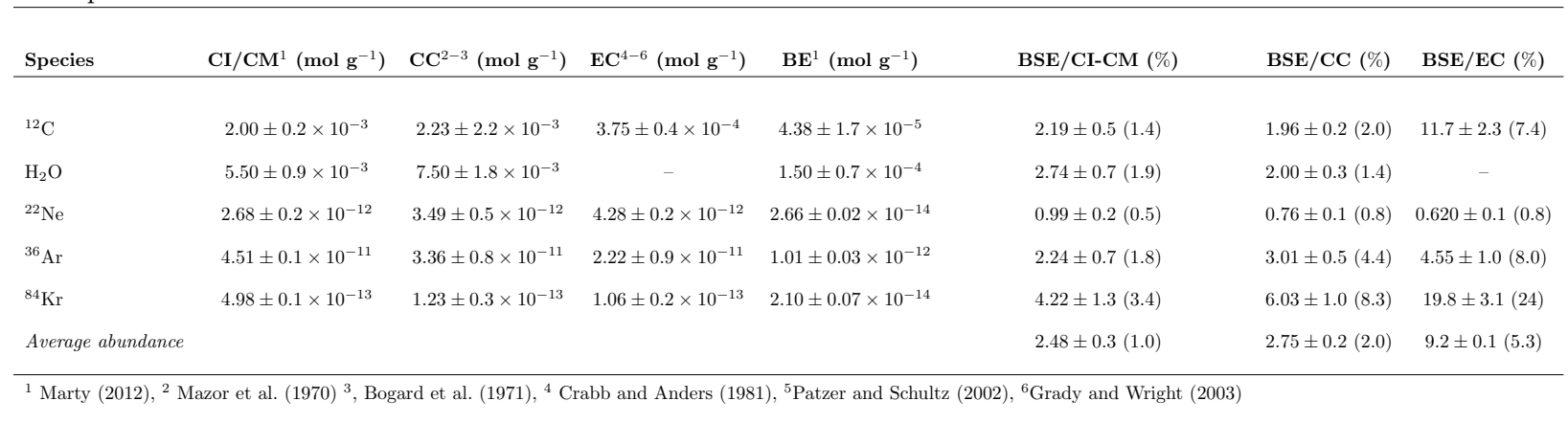

Table 3: Concentrations of $\mathrm{K}$ and $\mathrm{Rb}$ in carbonaceous chondrites (CC) and enstatite chondrites (EC), compared to their abundance in the BSE (BE). If $\mathrm{N}$ were present in the solar nebula as $\mathrm{NH}_{4}^{+}$, it may behave more similarly to these alkali elements than to noble gases. It is likely, however, that $\mathrm{N}$ would be more volatile than either $\mathrm{K}$ or $\mathrm{Rb}$, so these represent upper limit estimates for $\mathrm{N}$ abundance in the BSE, compared to chondrites.

\begin{tabular}{lccccc} 
Species & CC (ppm) & EC (ppm) & BE (ppm) & BE/CC (\%) & BE /EC (\%) \\
$\mathrm{Rb}$ & 1.7 & 2.5 & 0.6 & 35 & 24 \\
$\mathrm{~K}$ & 400 & 770 & 280 & 70 & 36 \\
\hline
\end{tabular}

removed from the rest of the planet. It is therefore important to constrain how much $\mathrm{N}$ is in the core, which will be subtracted from a chondritic starting composition.

There are several types of constraints provided (Table 4). The first is $\mathrm{N}$ measurements from iron meteorites, which are derived from cores of planetesimals formed early in the solar system's history (Grady and Wright, 2003). While variable, these meteorites have an average N content of $138 \pm 12$ ppm (Fig. 4), mostly contained in the mineral taenite $\left(\mathrm{Fe}_{0.8} \mathrm{Ni}_{0.2}\right)$. If iron meteorites are a good proxy for the core, it contains $250 \pm 20 \times 10^{18} \mathrm{~kg}$. Secondly, there are calculations, based on thermodynamic properties, indicating the partition coefficient between liquid iron and silicate melt $\left(\mathrm{K}_{\mathrm{D}}=[\mathrm{N}]_{\text {metal }} /[\mathrm{N}]_{\text {silicate }}\right)$ of $1.8 \pm 0.2$. This suggests $0.001 \mathrm{wt} \% \mathrm{~N}$ in the core, for a $\mathrm{N}$ content of $1.8 \pm 0.2 \times 10^{18} \mathrm{~kg}$ (Zhang and Yin, 2012). This estimate matches experimental work done at low pressures (e.g., Kadik et al., 2011), but does not agree with experimental work done at higher pressures appropriate for core formation conditions.

The third, and preferred, type of constraint uses our calculated CC- or EC-volatile proxies for BE N content in concert with experimental measurements of $\mathrm{K}_{\mathrm{D}}$ under high pressure (5-20 GPa). Measured $\mathrm{K}_{\mathrm{D}}$ is $20 \pm 10$ (Roskosz et al. 2013). The $\mathrm{N}$ concentration of the core can be calculated by using the following 
Table 4: Total Earth, core, and BSE N masses based on abundances (noble gas and $\mathrm{K}$ or Rb) calculated above and other proxies. Calculations from volatile and $\mathrm{K}$ or Rb proxies use distribution coefficients between silicate and Fe-metal at pressures and temperatures appropriate for core formation (Roskosz et al., 2013). Details are presented in the text. Additional core N estimates are obtained from thermodynamic calculation (Zhang and Yin, 2012) and analysis of iron meteorites (Grady and Wright, 2003). "Atm" is the current atmosphere $\left(4 \times 10^{18} \mathrm{~kg} \mathrm{~N}\right)$. All values are in $10^{18} \mathrm{~kg}$ N. We use the CC- and EC-volatile estimates in the remainder of the text, and these are shown in bold. Errors are $\mathrm{SE}_{\bar{x}}$

\begin{tabular}{|c|c|c|c|c|c|c|c|}
\hline Proxy & Bulk Earth N & Bulk Earth N (ppm) & Core $\mathrm{N}$ mass & Core N (ppm) & BSE+Atm & BSE only & BSE only (ppm) \\
\hline CC-volatile & $204 \pm 75$ & $34 \pm 12$ & $180 \pm 110$ & $102 \pm 63$ & $21 \pm 17$ & $17 \pm 13$ & $4.1 \pm 3.1$ \\
\hline EC-volatile & $330 \pm 120$ & $\mathbf{5 5} \pm \mathbf{2 0}$ & $300 \pm 180$ & $165 \pm 100$ & $35 \pm 28$ & $31 \pm 24$ & $7.3 \pm 5.6$ \\
\hline $\mathrm{K}-\mathrm{CC}$ & $5200 \pm 1850$ & $864 \pm 310$ & $4600 \pm 3500$ & $2580 \pm 2000$ & $530 \pm 400$ & $526 \pm 396$ & $128 \pm 116$ \\
\hline $\mathrm{Rb}-\mathrm{CC}$ & $2600 \pm 880$ & $430 \pm 150$ & $2300 \pm 1800$ & $1300 \pm 1000$ & $270 \pm 250$ & $255 \pm 246$ & $64 \pm 58$ \\
\hline $\mathrm{K}-\mathrm{EC}$ & $1300 \pm 500$ & $220 \pm 74$ & $1100 \pm 900$ & $650 \pm 500$ & $140 \pm 125$ & $136 \pm 121$ & $32 \pm 29$ \\
\hline Rb-EC & $870 \pm 300$ & $145 \pm 50$ & $780 \pm 600$ & $430 \pm 330$ & $90 \pm 80$ & $86 \pm 76$ & $19 \pm 0.8$ \\
\hline Iron Meteorite & & & $250 \pm 20$ & $140 \pm 10$ & & & \\
\hline Thermodynamic caluclation & & & $1.8 \pm 0.2$ & & & & \\
\hline
\end{tabular}

two relationships:

$$
\begin{gathered}
\mathrm{N}_{\mathrm{t}}=\mathrm{N}_{\mathrm{c}}+\mathrm{N}_{\mathrm{b}} \\
\mathrm{N}_{\mathrm{t}}=\left[\mathrm{N}_{\mathrm{c}}\right] \mathrm{M}_{\mathrm{c}}+\left[\mathrm{N}_{\mathrm{b}}\right] \mathrm{M}_{\mathrm{b}}
\end{gathered}
$$

where $\mathrm{M}$ is mass, $\mathrm{N}$ without brackets is $\mathrm{N}$ mass, $\mathrm{N}$ in brackets is concentration, and subscripts are $\mathrm{t}$ for total Earth, c for core, and b for BSE. Mass of the core is $1.8 \times 10^{24} \mathrm{~kg}$ and mass of the BSE is $4.2 \times 10^{24} \mathrm{~kg}$. Taking $\mathrm{K}_{\mathrm{D}}=\left[\mathrm{N}_{\mathrm{c}}\right] /\left[\mathrm{N}_{\mathrm{b}}\right]$, we find

$$
\left[\mathrm{N}_{\mathrm{c}}\right]=\frac{\mathrm{N}_{\mathrm{t}}}{\mathrm{M}_{\mathrm{c}}+\frac{\mathrm{M}_{\mathrm{b}}}{\mathrm{K}_{\mathrm{D}}}}
$$

A partition coefficient of $20 \pm 10$ and bulk Earth $\mathrm{N}$ mass that is either CC-like $\left(204 \pm 75 \times 10^{18} \mathrm{~kg}\right)$ or EC-like $\left(330 \pm 120 \times 10^{18} \mathrm{~kg}\right)$ suggests $180 \pm 110 \times 10^{18}$ or $300 \pm 180 \times 10^{18} \mathrm{~kg} \mathrm{~N}$ is in the core. These values are very similar to iron meteorites, suggesting they are a good proxy for core composition. Were the volatile concentration based on K-Rb, not noble gases, the $\mathrm{N}$ inventory would be $780-4600 \times 10^{18} \mathrm{~kg}$. Importantly, all proxies indicate that if $\mathrm{N}$ were present in the Earth during core formation, the majority of it is sequestered into the core. This may have had an isotopic effect on the $\mathrm{N}$ remaining in the BSE, though it may have been minimal due to the high temperature. No measurements of this fractionation have been made, to our knowledge.

We can estimate $\mathrm{N}$ remaining in the BSE and atmosphere by subtracting core $\mathrm{N}$ mass from the total Earth. This leaves $\mathrm{N}$ masses of $21 \pm 17 \times 10^{18} \mathrm{~kg}$ and $35 \pm 28 \times 10^{18} \mathrm{~kg}$ remaining in the BSE and atmosphere for CC-like and EC-like models, respectively. Further subtracting the amount in the modern atmosphere $\left(4 \times 10^{18} \mathrm{~kg} \mathrm{~N}\right)$, suggests between $17 \pm 13 \times 10^{18} \mathrm{~kg}$ and $31 \pm 24 \times 10^{18} \mathrm{~kg} \mathrm{~N}(4.1 \pm 3.1$ to $7.3 \pm 5.6 \mathrm{ppm})$ reside in the BSE. These estimates are higher than previous work for BSE N content, and serve as a useful comparison for the terrestrial-based, literature compilation budget presented in Section 4 


\subsection{A Lunar analogue for the Early Mantle?}

The Moon formed after a Mars-size proto-planet (Theia) collided obliquely with a Venus-size proto-Earth (Tellus) at the end of planetary accretion (Hartmann and Davis, 1975), marking the end of the so-called Chaotian Eon and the start of "Earth" history sensu stricto (Goldblatt et al., 2010). The density and composition of the Moon indicates that it formed after core-mantle differentiation on Earth. In addition, the identical O-isotope composition (Wiechert et al. 2001) of the Earth-Moon system indicates that the Moon-forming impact was energetic enough to homogenize the Earth and its impactor, Theia. Hence, Lunar rocks may sample the very early Earth mantle.

The N content of Lunar rocks can be used to estimate Lunar mantle, and therefore early Earth mantle, $\mathrm{N}$ concentrations. There are a few measurements of $\mathrm{N}$ in Lunar rocks, including basaltic glasses (3 ppm), basalts $(0.7 \mathrm{ppm})$, and anorthosites (1.5 ppm) (Mathew and Marti, 2001). We use the concentration from basalt glasses as is done for terrestrial basalts (Section 4.5), as these are most quickly quenched and have experienced the least amount of degassing. Lunar glasses appear to be petrogenetically related to Lunar mare basalts (Mathew and Marti, 2001), which have relatively well constrained melting conditions. These basalts are the result of partial melting of 1-10\% at a depth of $400 \mathrm{~km}(2.85 \mathrm{GPa}$, lower pressure than the equivalent depth on Earth due to the smaller Lunar mass) (Shearer and Papike, 1999) and temperatures of $1125^{\circ} \mathrm{C}$ (Marty et al., 2003). Oxygen fugacity is between IW-2 and IW-4 (Marty et al., 2003). By comparison, terrestrial mid-ocean ridge basalts (MORB) formed at much more oxidizing conditions of IW +6 (Frost and McCammon, 2008).

To use these data to calculate $\mathrm{N}$ concentration in the Lunar mantle, we calculate a hypothetical $\mathrm{K}_{\mathrm{D}}$ based on a basalt-source rock (peridotite) at the given $\mathrm{T}\left(1125{ }^{\circ} \mathrm{C}\right), \mathrm{P}(2.85 \mathrm{GPa})$, and $f_{\mathrm{O}_{2}}$ (IW-2 to IW-4) conditions (Table 5). First, N solubility in olivine, pyroxene, and melt are calculated using Eqs. 4. 5 , and 6. Next, bulk $\mathrm{K}_{\mathrm{D}}$ is calculated for a source rock is assumed to be $60 \%$ olivine and $40 \%$ pyroxene. These $\mathrm{K}_{\mathrm{D}}$ values, along with percent partial melt, are used in Eq. 7 to calculate $\mathrm{N}$ concentration in basalt glass source region, given glass concentration of $3 \mathrm{ppm}$ (Table 5). Thus we determine the average source $\mathrm{N}$ concentration for the Lunar mantle is $0.18 \pm 0.15 \mathrm{ppm}$.

This calculated concentration is lower than what is predicted from the chondritic model, but is similar to analyses of terrestrial xenoliths $(0.28 \pm 0.25 \mathrm{ppm}$, Sec. 4.5). The lunar value is interpreted as a lower limit for the $\mathrm{N}$ concentration of the early Earth mantle, as there may well have been substantial $\mathrm{N}$ loss during moon formation. Some N was likely volatilized and lost to space during the moon-forming impact, and later by degassing from a lunar magma-ocean. Although degassing from a magma ocean is possible, we note that under the reducing conditions thought to characterize the lunar mantle, a significant proportion of $\mathrm{N}$ present in melts is $\mathrm{NH}_{4}^{+}$(Libourel et al. 2003 Mysen et al. 2008). Ammonium can bond with Si-chains in a melt, and may be retained to a higher degree than $\mathrm{N}_{2}$, which dissolves in magmas by filling spaces in between Si-chains. This behaviour of "chemically solubility" or "physical solubility" for $\mathrm{NH}_{4}^{+}$and $\mathrm{N}_{2}$ might promote retention of $\mathrm{N}$ in the lunar mantle, and help it resist degassing and loss to space. 
Table 5: Estimates of Lunar $\mathrm{N}$ content in ppm, shown as a function of $f_{\mathrm{O}_{2}}$. Hypothetical mineral and melt $\mathrm{N}$ concentrations for conditions of basalt melting are calculated using Eq. 4.56 These are used to calculate $\mathrm{K}_{\mathrm{D}}$ for a source rock that is $60 \%$ olivine and $40 \%$ pyroxene. Source concentration based on measurements of glass (3 ppm) are calculated with Eq. 7

\begin{tabular}{lcc} 
Mineral (Modal \%) & $f_{\mathrm{O}_{2}}=\mathrm{IW}-2$ & $f_{\mathrm{O}_{2}}=\mathrm{IW}-4$ \\
Olivine (60\%) & 11 & 82 \\
Pyroxene (40\%) & 45 & 77 \\
Melt & 31,000 & 45,000 \\
Bulk K & $8 \times 10^{-4}$ & $1.8 \times 10^{-3}$ \\
& \multicolumn{1}{c}{ Expected source $\mathbf{N}(\mathbf{p p m})$} \\
& at bulk $\mathbf{K}_{\mathbf{D}}=\left(f_{\mathrm{O}_{2}}\right.$ as above $)$ \\
Percent Partial Melt & $\mathbf{8} \times \mathbf{1 0}^{-\mathbf{4}}$ & $\mathbf{1 . 8} \times \mathbf{1 0}^{-\mathbf{3}}$ \\
$1 \%$ & 0.03 & 0.04 \\
$10 \%$ & 0.3 & 0.3 \\
Average source rock concentration & & $0.18 \pm 0.15$ \\
\hline
\end{tabular}

\section{4. "Bottom-up" approach: terrestrial analyses}

In this section, we present our "bottom-up" approach. That is, using analyses of geologic materials to estimate the $\mathrm{N}$ budget of the Earth in its present state. We will not make a thorough attempt to describe how $\mathrm{N}$ cycling has changed in the past, but will discuss past cycles/characteristics where needed. We organize our budget starting with the best characterized reservoirs (atmosphere, ocean, biomass) then describing those that are less well known (geologic). Bulk reservoir masses (Table 7) are used in concert with estimated $\mathrm{N}$ concentrations to calculate $\mathrm{N}$ mass in poorly characterized reservoirs (Table 13). A more complete picture of the current state of $\mathrm{N}$ on Earth should provide a more solid springboard from which to leap into interpretations of past processes.

\subsection{Atmosphere}

$\mathrm{N}_{2}$ is the dominant form of $\mathrm{N}$ in the atmosphere; its mass $\left(4 \times 10^{18} \mathrm{~kg}\right)$ is calculated via Equation 13 using $\mathrm{m}_{\mathrm{a}}$ as molar mass dry air $\left(0.02897 \mathrm{~kg} \mathrm{~mol}^{-1}\right) ; x_{\mathrm{N}_{2}}=0.78 ; \mathrm{r}=6.4 \times 10^{6} \mathrm{~m} ; \mathrm{p}=1.014 \times 10^{5} \mathrm{~Pa}$; and $\mathrm{g}=9.8 \mathrm{~m} \mathrm{~s}^{-2}$.

Other $\mathrm{N}$ species in the atmosphere include $\mathrm{N}_{2} \mathrm{O}, \mathrm{NH}_{Y}\left(\mathrm{NH}_{3}, \mathrm{NH}_{4}^{+}\right)$, and $\mathrm{NO}_{X}\left(\mathrm{NO}, \mathrm{NO}_{2}^{-}, \mathrm{NO}_{3}^{-}\right)$. These are minor species, with abundances of $1.5 \times 10^{12}, 1.7 \times 10^{9}$, and $7 \times 10^{8} \mathrm{~kg} \mathrm{~N}$, respectively Ussiri and Lal, 2013). 
Table 6: Well characterized surficial $\mathrm{N}$ reservoirs, including the atmosphere, ocean, and biomass.

\begin{tabular}{lcc} 
Reservoir & Form & Size $\left(10^{18} \mathbf{k g ~ N}\right)$ \\
\hline Atmosphere & $\mathrm{N}_{2}$ & 4.0 \\
$\mathrm{~N}_{2} \mathrm{O}$ & $1.5 \times 10^{-6}$ \\
$\mathrm{NH}_{Y}$ & $1.7 \times 10^{-9}$ \\
$\mathrm{NO}_{X}$ & $7 \times 10^{-10}$ \\
Oceans & $\mathrm{N}_{2}$ & $2.4 \times 10^{-2}$ \\
& $\mathrm{NO}_{3}$ & $5.7 \times 10^{-4}$ \\
& $\mathrm{NH}_{Y}$ & $7 \times 10^{-6}$ \\
$\mathrm{~N}_{2} \mathrm{O}$ & $2 \times 10^{-7}$ \\
Biomass & Ocean Living & $5 \times 10^{-7}$ \\
& Ocean Dead Organic Matter & $8 \times 10^{-4}$ \\
& Continental Living & $1.1 \times 10^{-5}$ \\
& Soil organics & $1.3 \times 10^{-4}$ \\
\hline
\end{tabular}

\subsection{Oceans}

The $\mathrm{N}$ content of the oceans is small compared to the atmosphere. Dissolved $\mathrm{N}_{2}$ is the main $\mathrm{N}$ species in the ocean, with a mass of about $2.4 \times 10^{16} \mathrm{~kg}$ (Ussiri and Lal, 2013). Concentrations of minor species $\left(\mathrm{NO}_{3}^{-}\right.$, $\mathrm{NH}_{4}^{+}, \mathrm{N}_{2} \mathrm{O}$ ) can vary over the year, spatially, and with depth. Surface $\mathrm{NO}_{3}^{-}$concentration is typically higher in the winter, due to lower productivity, but varies throughout the year at concentrations of 0-30 $\mu \mathrm{M}$ (Garcia et al. 2010). $\mathrm{NO}_{3}^{-}$at depth is more constant spatially and is found at higher concentrations, between 10-35 $\mu \mathrm{M}$. Total $\mathrm{NO}_{3}^{-}$in the ocean has a mass of $5.7 \times 10^{14} \mathrm{~kg} \mathrm{~N}$ (Ussiri and Lal, 2013). On average, the $\mathrm{NH}_{4}^{+}$ is found at a concentration of $0.4 \mu \mathrm{M}$, and $\mathrm{N}_{2} \mathrm{O}$ at a concentration of $11 \mathrm{nM}$. These concentrations yield masses of $7 \times 10^{12}$ and $2 \times 10^{11} \mathrm{~kg} \mathrm{~N}$, respectively.

Concentrations of $\mathrm{N}$ species also depend on redox conditions. In deep waters of the Black Sea, which are anoxic, $\mathrm{NH}_{4}^{+}$is the dominant $\mathrm{N}$ species, with concentrations of up to $40 \mu \mathrm{M}$, while $\mathrm{NO}_{3}^{-}$concentration is negligible (Fuchsman et al. 2008). A similar relationship is seen during the winter in Saanich Inlet on Vancouver Island, with deep anoxic waters dominated by $\mathrm{NH}_{4}^{+}(10 \mu \mathrm{M})$ instead of $\mathrm{NO}_{3}^{-}(<0.2 \mu \mathrm{M})$ Velinsky et al. 1991).

\subsection{Biomass}

The mass of $\mathrm{N}$ in living biomass is small compared with dissolved $\mathrm{N}_{2}$ (above) and inorganic $\mathrm{N}$ species. Living biomass in the ocean contains about $5 \times 10^{11} \mathrm{~kg}$ N. Marine dead organic matter is a much more 


\begin{tabular}{|c|c|c|c|c|}
\hline Reservoir & Density $\left(\mathrm{g} / \mathrm{cm}^{3}\right)$ & Thickness (km) & Area $\left(\mathrm{km}^{2}\right)$ & Mass (kg) \\
\hline Oceanic Sediments ${ }^{1}$ & - & - & - & $7.4 \times 10^{20}$ \\
\hline Oceanic Lithosphere & 3 & 50 & $3.61 \times 10^{8}$ & $5.4 \times 10^{22}$ \\
\hline Continental Crust $^{2}$ & - & - & - & $1.9 \times 10^{22}$ \\
\hline MORB-source Upper Mantle & 4 & 400 & $3.61 \times 10^{8}$ & $5.8 \times 10^{23}$ \\
\hline Off-cratonic Upper Mantle ${ }^{3}$ & 4 & 400 & $6 \times 10^{7}$ & $9.6 \times 10^{22}$ \\
\hline Cratonic Upper Mantle $^{3}$ & 4 & 400 & $9 \times 10^{7}$ & $1.4 \times 10^{23}$ \\
\hline Transition Zone ${ }^{4}$ & 4.4 & 240 & volume $=1.1 \times 10^{11} \mathrm{~km}^{3}$ & $4.8 \times 10^{23}$ \\
\hline Lower Mantle & - & - & - & $2.93 \times 10^{24}$ \\
\hline References are: ${ }^{1}$ Veizer and Mac & enzie (2003), ${ }^{2}$ Taylor & dd McLennan (1995) & ${ }^{3}$ (Lee et al., 2011$),{ }^{4} \mathrm{Gu}$ and & lewonski $(2001)$ \\
\hline
\end{tabular}

substantial reservoir, comparable to inorganic fixed N, with $8 \times 10^{14} \mathrm{~kg} \mathrm{~N}$ (Ussiri and Lal, 2013).

Soil and terrestrial biomass constitute a reservoir of $\mathrm{N}$ comparable to oceanic biomass. Soil has a $\mathrm{N}$ content of $1.62 \times 10^{14} \mathrm{~kg}$ and living biomass has a $\mathrm{N}$ mass of $1.1 \times 10^{13} \mathrm{~kg}$ (Ussiri and Lal, 2013) .

Despite its low mass in biomass, we emphasize the importance of biology in fixing N. This process is responsible for transferring $\mathrm{N}$ from the atmosphere into other reservoirs in the Earth.

\subsection{The Crust}

\subsubsection{Oceanic Sediments}

Nitrogen concentration in oceanic sediments is ultimately controlled by local biologic activity. In the modern ocean, primary productivity is higher near continental margins. Proximity to continental margins increases the available nutrient pool via river/weathering input and upwelling nutrient-rich deep waters (Gruber and Sarmiento, 1997). Consequently, primary productivity is higher near continental margins. Higher productivity leads to greater organic matter concentration, and the potential for more $\mathrm{N}$ to be deposited in sediments. Indeed, concentrations of $\mathrm{N}$ in sediments off the Central American margin have $>1000$ ppm N in some locations, with an average of about 770 ppm (Li and Bebout, 2005). This is notably higher than sediments from the Izu-Bonin-Mariana arc (IBM) in the western Pacific, which is further from continental margins, has lower primary productivity, and an average N content of about $280 \mathrm{ppm}$ (Sadofsky and Bebout, 2004).

Our $\mathrm{N}$ abundance estimate in oceanic sediments is based on the proportion of three sediment types covering the sea floor. All samples that are younger than $250 \mathrm{Ma}$ are used, since this is the maximum 
Table 8: Concentration of $\mathrm{N}$ in oceanic sediments, crust, and lithospheric mantle. All are shown with standard error of the mean $(\mathrm{SE} \bar{x})$. Samples used in budget estimates are $250 \mathrm{Ma}$ or younger, as this is the maximum age of oceanic crust. Oceanic crust and altered includes basalts and gabbros. Metamorphosed oceanic crust comprises basalts, gabbros, blueschists, and eclogites. MORB-source mantle includes peridotite (harzburgite or uncategorized), while altered MORB-source mantle also includes serpentinite. Note that metamorphosed oceanic crust and altered MORB-source mantle samples may be older than 250 Ma.

\section{Concentration (ppm)}

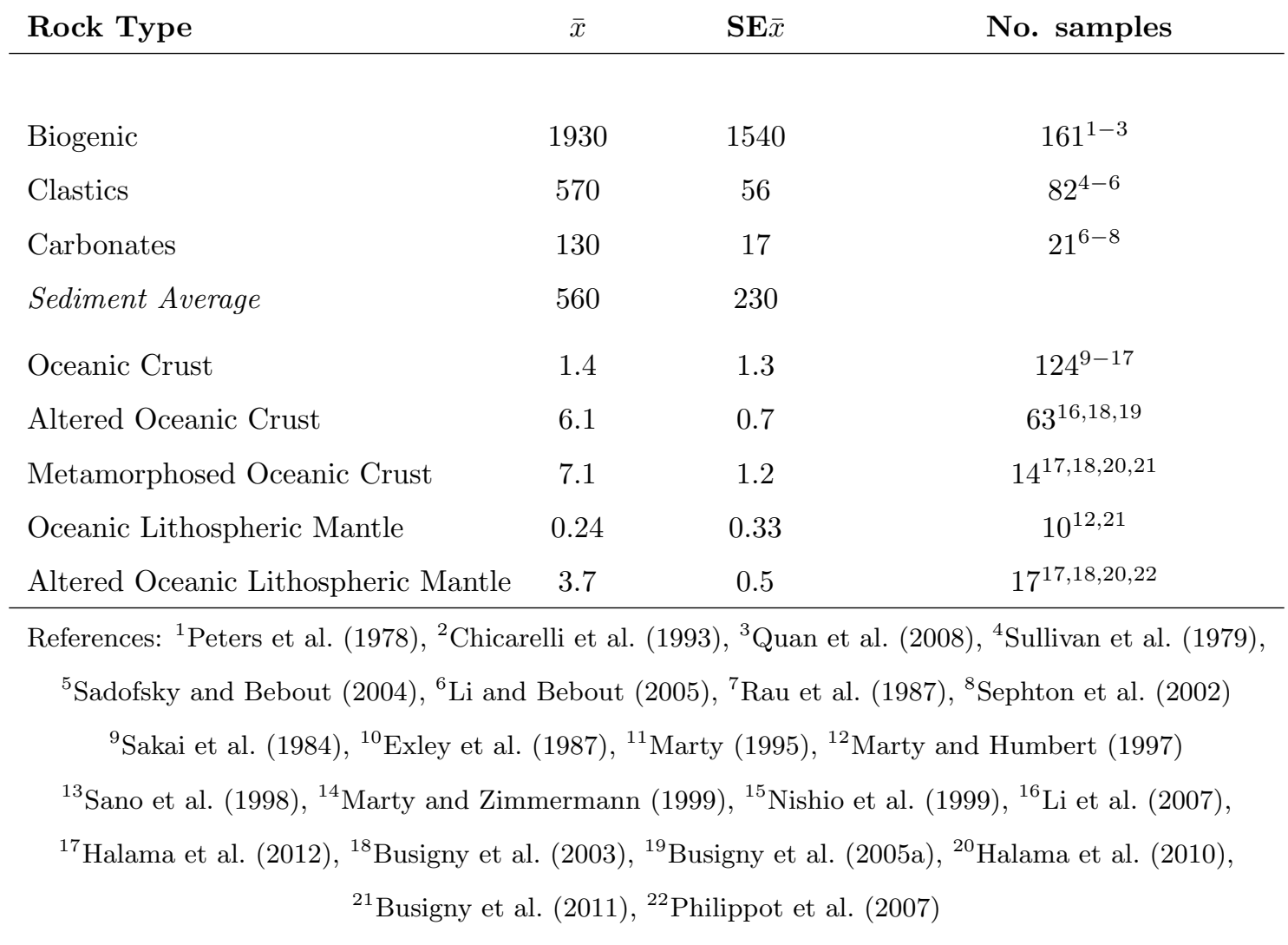




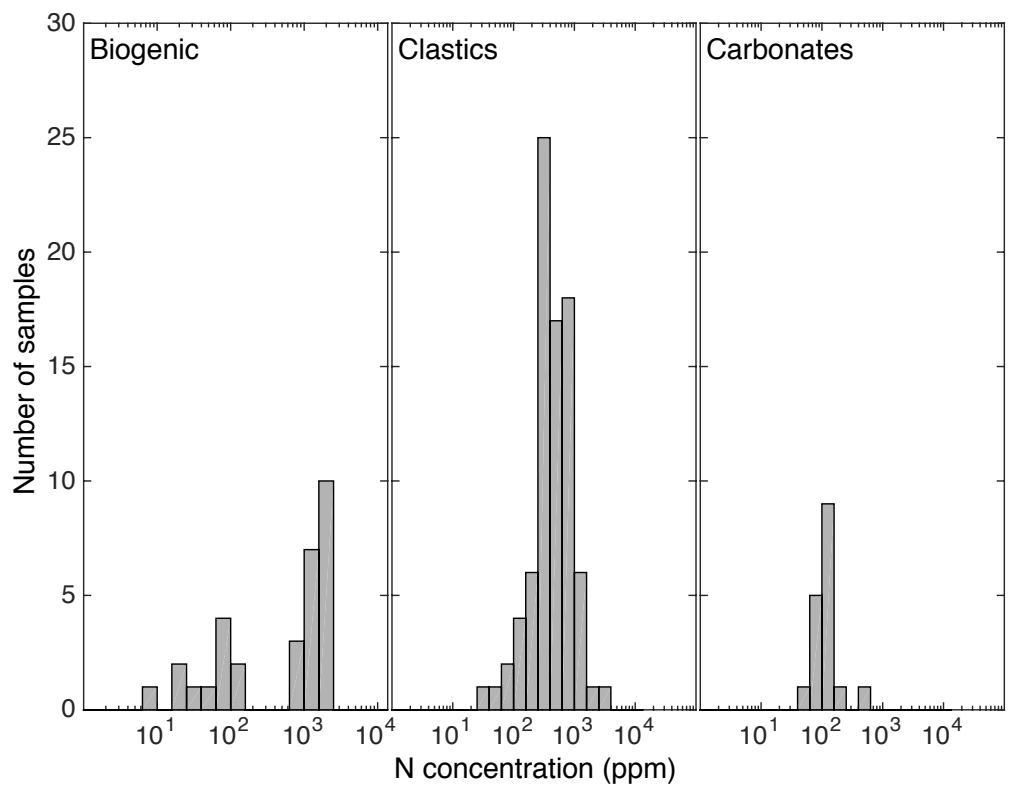

Figure 5: Nitrogen concentrations in oceanic crust less than 250 Ma. Sediments are separated into biogenic (organic materials, kerogen, graphite, microbialite, chert), clastic (siltstone, mudstone, clay, shale, sandstone, and pelite), and carbonates (limestone, dolostone). Oceanic lithosphere samples are labeled as OL and AOL.

age of oceanic basins. Current sedimentary cover on the sea floor is composed of carbonate (47.1\%), clastic (38.1\%), and biogenic (14.8\%) sediments (Davies and Gorsline, 1976 Brown et al., 1989). Biogenic sediments include organic materials, kerogen, graphite, microbialite, and chert and have a mean $\mathrm{N}$ concentration of $1930 \pm 1540$ ppm (Fig 5. Table 8). Clastic sediments include siltstone, mudstone, clay, shale, sandstone, and pelite and have a mean $\mathrm{N}$ concentration of $570 \pm 56 \mathrm{ppm}$. Carbonates, limestone and dolostone, have a mean $\mathrm{N}$ concentration of $130 \pm 17 \mathrm{ppm} \mathrm{N}$. The resulting weighted average is $560 \pm 230 \mathrm{ppm}$, which yields a $\mathrm{N}$ content for oceanic sediments of $0.41 \pm 0.2 \times 10^{18} \mathrm{~kg}$ (Table 13 ).

An important consideration when attempting to estimate $\mathrm{N}$ contents in the past is the redox conditions of the overlying water column, as sediments deposited under anoxic water conditions may be more N-rich. A sediment core from the Black Sea shows that sediments deposited under an anoxic water column have twice the $\mathrm{N}$ content (1800 ppm) as sediments deposited under an oxic water column (900 ppm) (Quan et al. 2013b). Changes in redox sensitive metal (Fe, Mo) concentrations and lack of significant changes in total organic carbon and $\delta^{13} \mathrm{C}$ values corroborate redox control over $\mathrm{N}$ concentration, as opposed to a purely biological control. The increase of $\mathrm{N}$ content with reducing conditions may not be universal, as some shale units do not show $\mathrm{N}$ enrichment under anoxic conditions. They do, however, show distinct $\delta^{15} \mathrm{~N}$ values that appear to reflect redox conditions (Quan et al., 2013a).

\subsubsection{Oceanic Crust and Upper Lithosphere}

Fresh gabbros and basalts at mid-ocean ridges inherit $N$ from their mantle source (Marty, 1995). Since these magmas are oxidized, $\mathrm{N}$ present in fresh MORB is typically found as $\mathrm{N}_{2}$ locked in fluid inclusions 


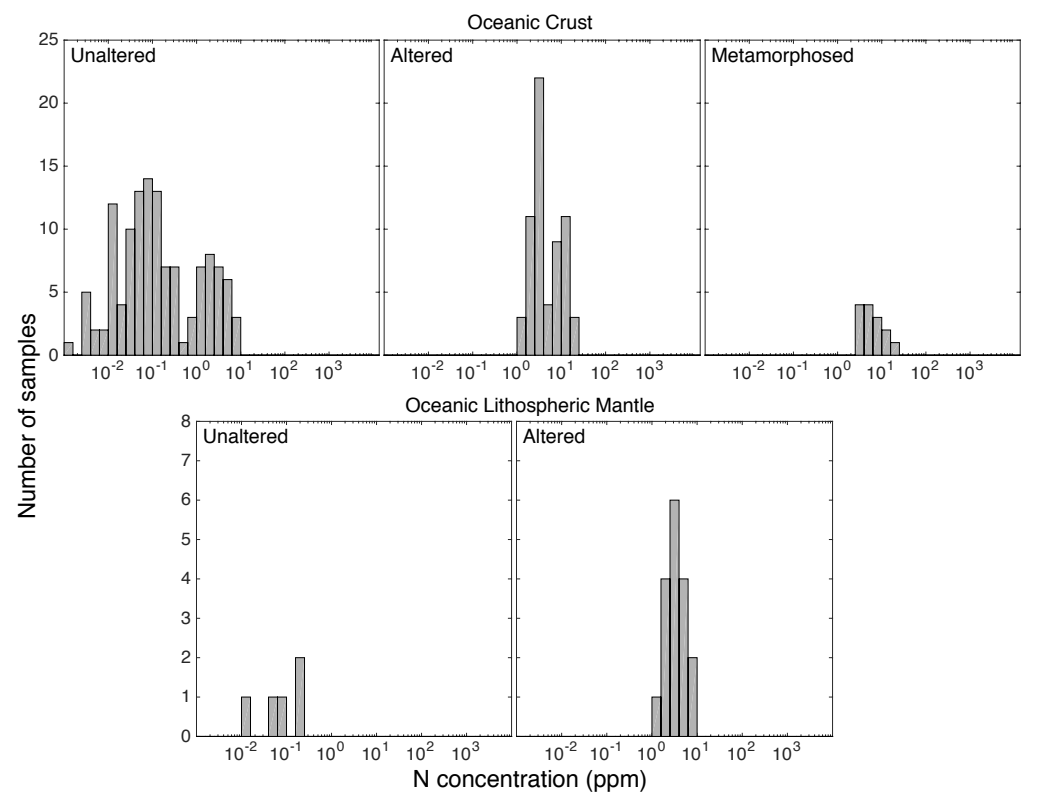

Figure 6: Nitrogen concentrations in oceanic crust and lithospheric mantle. Hydrothermal alteration increases the N content of oceanic crust, and it retains high $\mathrm{N}$ even during metamorphism. The same increase is seen in the oceanic lithospheric mantle. Samples are as in Table 8

in glassy rims. Concentrations in fresh crust are low, with an average of $1.4 \pm 1.3 \mathrm{ppm}$. Concentration is unaltered lithospheric mantle (defined here as harzburgite and undifferentiated peridotite) is also low, at $0.24 \pm 0.33$ ppm (Fig. 6. Table 8).

Hydrothermal alteration tends to increase the $\mathrm{N}$ content of the rocks, to an average of $6.1 \pm 0.7 \mathrm{ppm}$ for crustal rocks (altered basalts and gabbros) and $3.7 \pm 0.5 \mathrm{ppm}$ for lithospheric mantle (harzburgite and serpentinite). The source of this $\mathrm{N}$ is from biologic activity in seawater, identified by positive $\delta^{15} \mathrm{~N}$ values. As seawater enters a hydrothermal system, it carries $\mathrm{NH}_{4}^{+}$from overlying sediments into the crust and mantle (e.g., Halama et al. 2010). $\mathrm{NH}_{4}^{+}$substitutes into mineral lattices of hydrothermal minerals, most importantly K-bearing clays. It is possible that some $\mathrm{N}$ may be present as $\mathrm{N}_{2}$ in cordierite (Palya et al., 2011).

Since hydrothermal alteration is the main control on geologically stable $\mathrm{N}$ in oceanic crust, estimates of $\mathrm{N}$ concentration in these rocks depend on the depth and extent of hydrothermal alteration into the lithosphere. The deepest cores show that alteration occurs at least to a depth of $470 \mathrm{~m}$ (Li et al., 2007). Metagabbros and serpentinized mantle rocks in ophiolites show that alteration can reach even deeper, into the upper mantle. Hydrothermal origin of $\mathrm{N}$ is confirmed by enriched $\delta^{15} \mathrm{~N}$ values, derived from oceanic biologic processes (Busigny et al., 2011, Halama et al. 2012). Some ophiolites experienced metamorphic pressures of up to 2.5 GPa ( $80-90 \mathrm{~km}$ depth), yet still retain $\mathrm{N}$ derived from the ocean, indicating the durability of the $\mathrm{NH}_{4}^{+}$silicate bond. Indeed, the concentration of $\mathrm{N}$ in metamorphosed oceanic crust (basalt, gabbro, blueschist, eclogite) is identical within error $(7.1 \pm 1.2 \mathrm{ppm})$ to altered crust.

A $\mathrm{N}$ budget estimate for the oceanic lithosphere can be calculated assuming shallow or deep alteration. 
Shallow alteration affecting the entire crust $(6.1 \pm 0.7 \mathrm{ppm}), 0.5 \mathrm{~km}$ of mantle $(3.7 \pm 0.5 \mathrm{ppm})$, with the remainder of the mantle $(9.5 \mathrm{~km})$ at $0.24 \pm 0.33 \mathrm{ppm} \mathrm{N}$, yields a $\mathrm{N}$ concentration of $2.9 \pm 0.3 \mathrm{ppm}$. This concentration gives $\mathrm{N}$ mass of $0.16 \pm 0.02 \times 10^{18} \mathrm{~kg} \mathrm{~N}$. If alteration occurs on a lithospheric scale $(8 \mathrm{~km}$ crust and $10 \mathrm{~km}$ mantle), we calculate an upper estimate of $4.8 \pm 0.4 \mathrm{ppm} \mathrm{N}$, which gives total $\mathrm{N}$ mass of $0.26 \pm 0.02 \times 10^{18} \mathrm{~kg} \mathrm{~N}$. While these values are orders of magnitude less than the amount of $\mathrm{N}$ contained in the atmosphere, $\mathrm{N}$ in the oceanic crust is of critical importance as subduction over long time scales has the potential to transport a large amount of $\mathrm{N}$ into the mantle.

An average column of oceanic crust, sediments, and lithosphere can subduct substantial $\mathrm{N}$ over Earth history. A column with $500 \mathrm{~m}$ of sediment (560 ppm N, Table 8) and the conservative oceanic crust plus lithosphere concentration of $2.9 \pm 0.3 \mathrm{ppm}$ gives an average column concentration of $18 \mathrm{ppm}$. If we assume that all $\mathrm{N}$ gets subducted, which depends on temperature and varies by subduction zone, we can multiply this concentration times the mass of oceanic slab being subduction each year $(\sim 40,000 \mathrm{~km}$ trench length, $18.5 \mathrm{~km}$ thick crust, $5 \mathrm{~cm} / \mathrm{yr}$ convergence rate, and density of $3.5 \mathrm{~g} / \mathrm{cm}^{3}$ ), and calculate that $2.3 \times 10^{9} \mathrm{~kg} \mathrm{~N}$ are subducted every year. Over Earth history (4 Ga, for illustrative purposes), current subduction equates to $9.3 \times 10^{18} \mathrm{~kg} \mathrm{~N}$, which is twice the current mass of $\mathrm{N}$ in the atmosphere. It therefore seems reasonable to suggest that the entire atmosphere may have passed through the mantle at least once, given current subduction efficiency, or more times if subduction of $\mathrm{N}$ was more efficient in the past (Sec. 5).

\subsubsection{Continental Crust}

The continental crust is composed of two categories of rocks: (meta)sedimentary and (meta)igneous. We base our estimate for the $\mathrm{N}$ budget of the continental crust on our literature compilation and the rock abundance estimates of Wedepohl 1995) (Table 9). These proportions are based on surface outcrop area for upper crustal rocks and xenolith data for lower crustal rocks. 


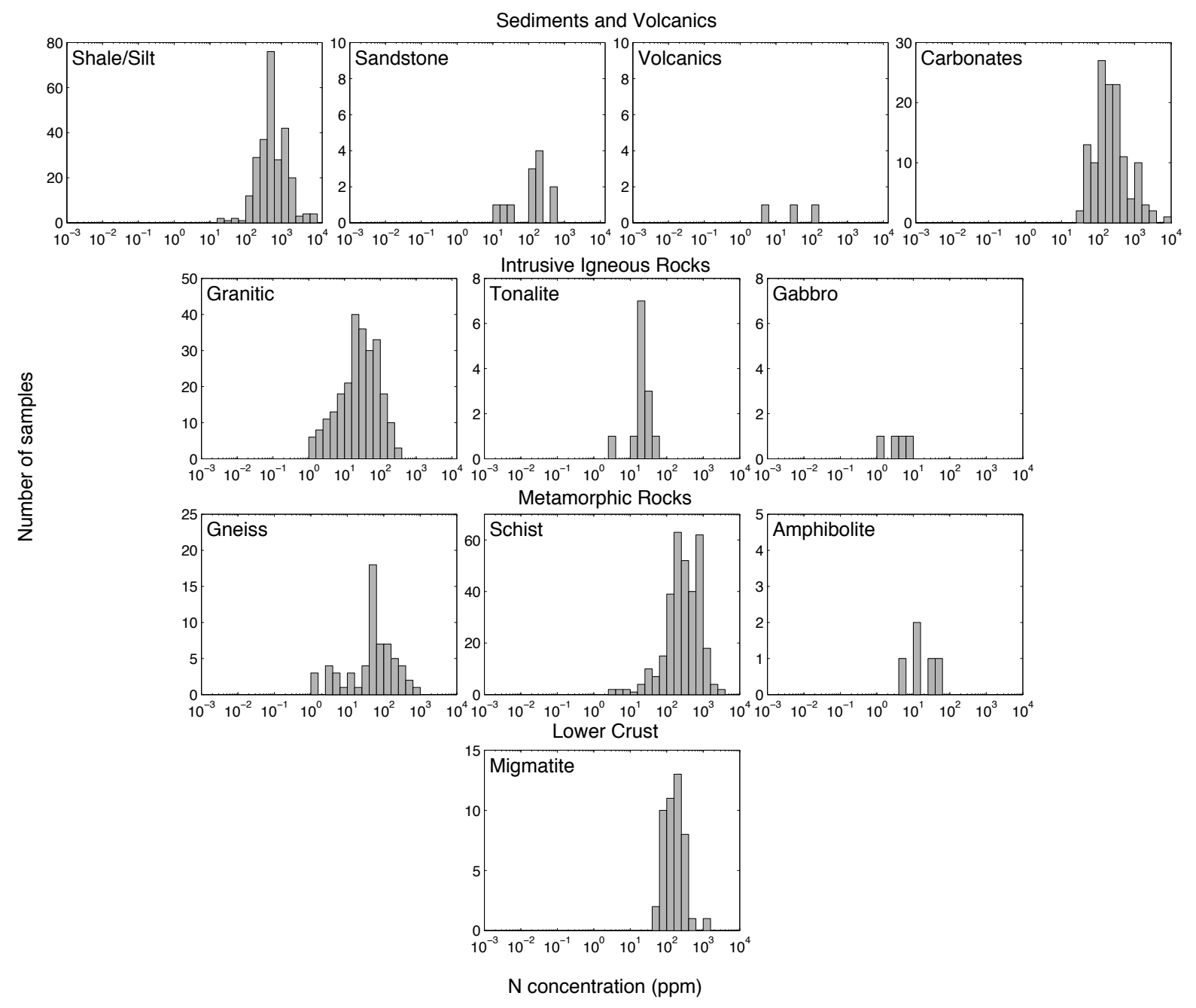

Figure 7: N concentrations in continental crust. Panels are organized from shallow to deep levels in the crust. See Table 9 for average $\mathrm{N}$ concentrations. 
Table 9: Estimates for the amount of $\mathrm{N}$ in the continental crust, shown with standard error of the mean (with an arbitrary error of $50 \%$ for very poorly known rock types). Rock proportions are based on Wedepohl (1995), who based upper crustal rock abundances on mapped area and lower crustal abundance on xenoliths.

\section{Conentration (ppm)}

$\begin{array}{llllll}\text { Reservoir (\% of crust) } & \text { Rock type (\% of reservoir) } & \bar{x} & \text { SE } \bar{x} & \text { No. samples }\end{array}$

\section{Upper Crust (53\%)}

Sedimentary/Volcanic Rocks (14\%)

Felsic Intrusives (50\%)

Mafic Intrusives (6\%)

Metamorphic rocks (30\%)

$$
\begin{gathered}
\text { Shale/Silt }(44 \%) \\
\text { Sandstone }(21 \%) \\
\text { Volcanics }(20 \%) \\
\text { Carbonates }(14 \%) \\
\text { Average } \\
\text { Granitic (90\%) } \\
\text { Tonalite }(10 \%) \\
\text { Average } \\
\text { Gabbros }(100 \%) \\
\text { Gneisses }(64 \%) \\
\text { Mica Schist }(16 \%) \\
\text { Amphibolites }(18 \%) \\
\text { Marble }(3 \%) \\
\text { Average }
\end{gathered}
$$

\section{Upper Crust Average}

\section{Lower Crust (47\%)}

Felsic/Mafic Granulites (62\%)

Mafic Granulites (38\%)

\section{Lower Crust Average}

Total crust average

$\begin{array}{ccl}860 & 64 & 261^{1-11} \\ 230 & 110 & 12^{12-16} \\ 50 & 60 & 3^{2,14} \\ 130 & 17 & 17^{\text {see Table } 8} \\ 455 & 38 & \end{array}$

54

24

52

5

135

500

7

$247^{14,17-29}$

4

6

2

50

44

22

1000

10

$500(?)$

$13^{2,18,27-28}$

200

36

150

12

17

6

6

17

17

6

120

Continental Crust $\mathrm{N}$ estimate $=1.7 \pm 0.1 \times 10^{18} \mathrm{~kg} \mathrm{~N}$

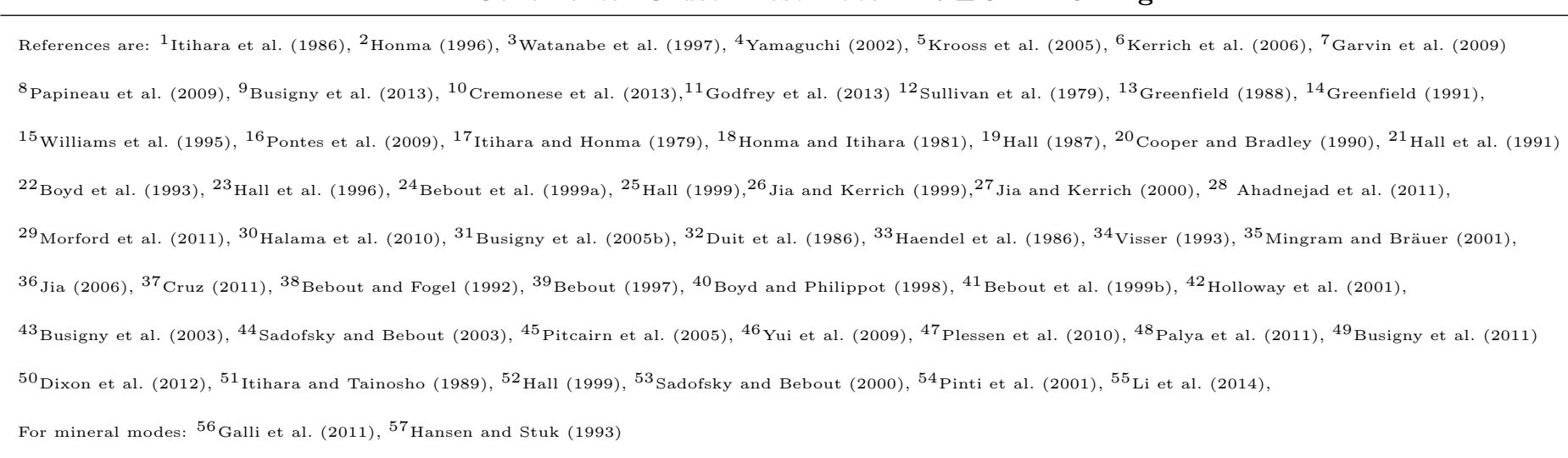


Upper crustal rocks are, unsurprisingly, the most analyzed and well characterized. Clastic sediments (especially shales) are the most sampled, and these include both samples explicitly formed in continental settings and sediments that formed in oceanic settings and are older than 250 Ma. Samples with oceanic provenance older than 250 Ma must now be preserved on continents in order to be sampled, so are included in the continental $\mathrm{N}$ budget. Nitrogen in continental sedimentary rocks is incorporated as organic matter, $\mathrm{NH}_{4}^{+}$from the breakdown of organic matter (as described previously), or $\mathrm{NH}_{4}^{+}$in minerals weathered from crystalline rocks.

Crystalline rocks, both igneous and metamorphic, form the majority of the upper continental crust. Nitrogen in both rock types is predominantly $\mathrm{NH}_{4}^{+}$, either inherited from source rocks (for igneous) or protoliths (for metamorphic). The presence of biotite exerts a strong control over the distribution of $\mathrm{N}$, as biotite has a strong affinity for $\mathrm{NH}_{4}^{+}$when compared to other $\mathrm{K}^{+}$-bearing minerals Honma and Itihara, 1981). Retention of $\mathrm{NH}_{4}^{+}$in a source region is also promoted by reduced melting conditions. In contrast, more oxidized melt conditions or less biotite-rich sources should preferentially move $\mathrm{NH}_{4}^{+}$into the melt, and therefore into granites, though some $\mathrm{NH}_{4}^{+}$may oxidize to $\mathrm{N}_{2}$, and either escape the melt or become trapped in fluid inclusions (Hall, 1999).

Hydrothermal alteration, especially if fluids pass through sedimentary country rock, will increase the concentration of $\mathrm{N}$ in crystalline rocks. For example, globally, unaltered granitic rocks have an average $\mathrm{N}$ concentration of $36 \pm 4 \mathrm{ppm}$; globally, altered granitic rocks average $65 \pm 17 \mathrm{ppm} \mathrm{N}$, with concentrations up to 250 ppm (e.g., Boyd et al., 1993; Holloway and Dahlgren, 2002).

$\mathrm{N}$ analyses from the deeper crust are sparse, but recent measurements suggest that this might be an important long-term reservoir for $\mathrm{N}$ (Palya et al. 2011). To calculate the mass of lower crust N, we use two well studied outcrops to represent the average mineralogy of both mafic (Cone Peak, California) (Hansen and Stuk, 1993) and felsic (Gruf Complex, eastern Alps) (Galli et al. 2011) granulites. The majority of N in these rocks should be contained in biotite and potassium feldspar, with some in plagioclase in a ratio of 1:0.38:0.11 (Honma and Itihara, 1981). Mafic granulites have 17\% biotite, 59\% plagioclase, and negligible potassium feldspar; felsic granulites have $17 \%$ biotite, $17 \%$ plagioclase, and $10 \%$ potassium feldspar. Globally, average $\mathrm{N}$ content of biotite in metamorphosed continental igneous and sedimentary rocks is $87 \pm 22 \mathrm{ppm}$, which in turn suggests plagioclase (in equilibrium) has $10 \pm 2 \mathrm{ppm}$ and potassium feldspar $33 \pm 8 \mathrm{ppm}$. Thus, mafic and felsic granulites have similar $\mathrm{N}$ concentrations of $17 \pm 6 \mathrm{ppm}$ (Table 9 ).

Our total continental crust estimate, $1.7 \pm 0.1 \times 10^{18} \mathrm{~kg} \mathrm{~N}$ (Table 9), suggests a substantial amount of $\mathrm{N}$ may be sequestered in the continental crust. This estimate is equivalent to a recent rough estimate (Goldblatt et al., 2009), but higher than another recent study (Rudnick and Gao, 2014) based on older compilations (Wedepohl, 1995) and measurements (Wlotzka, 1972).

\subsection{The Mantle}

The large mass of the mantle, compared to the atmosphere, means that it contains substantial N, even at low concentration. For example, $1 \mathrm{ppm} \mathrm{N}$ in the mantle would give $\mathrm{N}$ mass of $4 \times 10^{18} \mathrm{~kg}$, which is the 


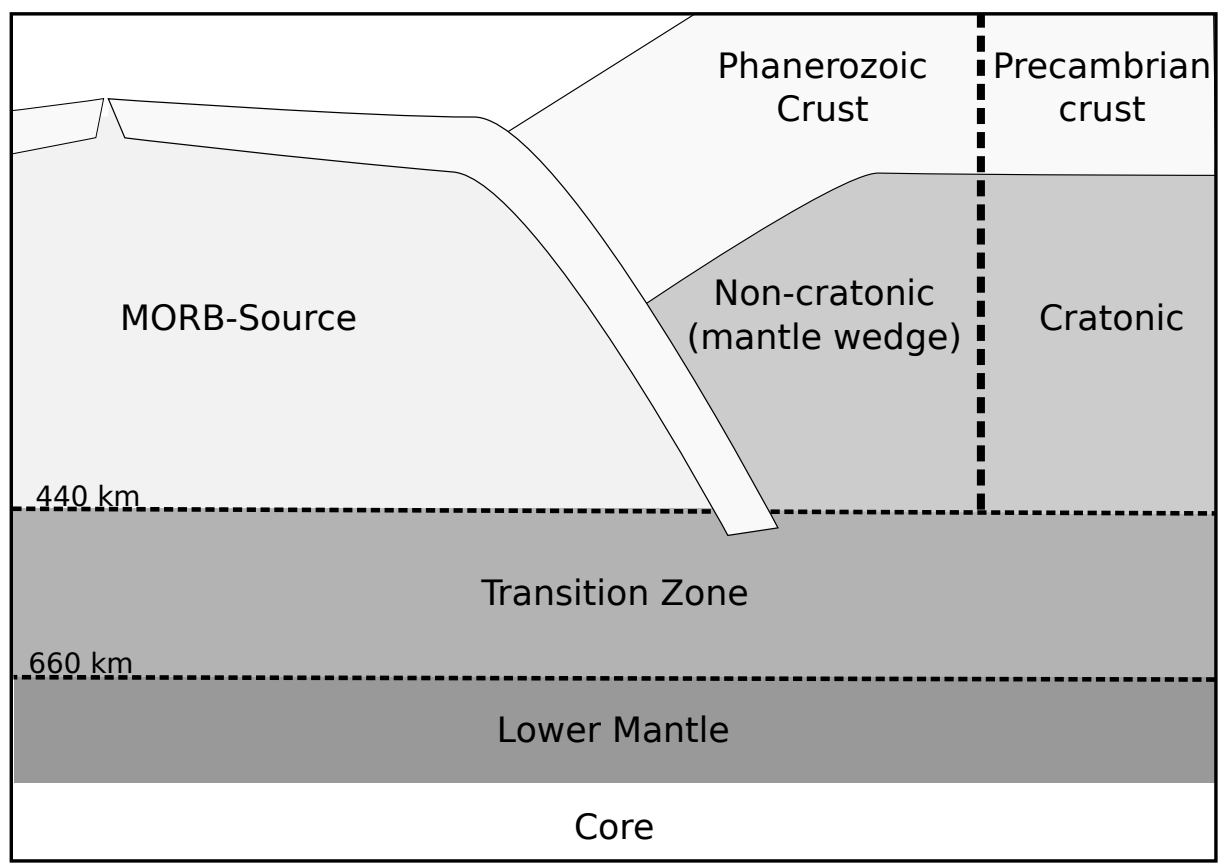

Figure 8: Mantle reservoirs as defined for individual domain-based budget (Section 4.5.2. The transition zone and lower mantle are defined by mineral phase changes. The mass of non-cratonic and cratonic mantle is estimated by multiplying the area of Phanerozoic-aged crust and pre-Cambrian crust by the depth to the top of the transition zone.

same as the atmosphere. Determining the actual abundance of $\mathrm{N}$ in the mantle is difficult, as $\mathrm{N}$ analyses are rare. Most information concerning volatile elements is from noble gas geochemistry, which is augmented by diamond analyses, xenoliths, and direct mantle melts. We can estimate the $\mathrm{N}$ content of the mantle either as a whole or by breaking it into different domains. First we calculate a whole-mantle estimated based on $\mathrm{N}$-Ar geochemistry. Then, we discuss distinct domains (MORB-source, OIB-source, off-cratonic, cratonic) individually, and base $\mathrm{N}$ estimates on analyses of xenoliths where available, as well as detail potential $\mathrm{N}$ capacity in unsampled domains (transition zone, lower mantle).

\subsubsection{Argon geochemistry-based estimate}

Nitrogen and Ar behave similarly in basaltic melts under oxidizing conditions (e.g., Libourel et al., 2003. Roskosz et al., 2006, Mysen and Fogel, 2010, Li et al., 2014, 2015), so N-Ar systematics may be used to calculate whole-mantle N budgets (Marty, 1995, Marty and Humbert, 1997, Dauphas and Marty, 1999. Marty and Zimmermann, 1999; Goldblatt et al. 2009). This approach is valid for both MORB and OIB, since they are generated from melting of oxidized upper mantle, even though they are geochemically distinct (White, 2010). There are a number of measurements of $\mathrm{N}_{2}$ and $\mathrm{Ar}$ in both basalt types, which can be used to estimate $\mathrm{N}$ concentration in their source. Calculating the amount of $\mathrm{N}$ in MORB-source and OIB-source mantle depends on establishing three criteria: (a) the amount of Ar in MORB- and OIB-source mantle, (b) the relationship between $\mathrm{N}$ and $\mathrm{Ar}$ in MORB and OIB, and (c) the proportion of mantle that is MORBand OIB-source. 
Before calculating the $\mathrm{N}$ mantle budget, we highlight some aspects of Ar geochemistry, as these are crucial to the following interpretation. Argon has three isotopes, ${ }^{36} \mathrm{Ar},{ }^{38} \mathrm{Ar}$, and ${ }^{40} \mathrm{Ar}$. The first two are primordial (i.e., inherited during planetary formation), while the third is produced by radioactive decay of ${ }^{40} \mathrm{~K}$, and has been increasing over time. Both primordial isotopes are found almost exclusively in the atmosphere, though minor amounts are degassing from the mantle. The radiogenic isotope, ${ }^{40} \mathrm{Ar}$, is present in both the atmosphere and the BSE, since $\mathrm{K}$ is found in the solid Earth. Thus, we chose to compare $\mathrm{N}$ to ${ }^{40} \mathrm{Ar}$, as both elements are found in the atmosphere and BSE; these data are normalized to primordial ${ }^{36} \mathrm{Ar}$.

The first step needed to estimate $\mathrm{N}$ content from ${ }^{40} \mathrm{Ar}$ is to calculate the amount of ${ }^{40} \mathrm{Ar}$ present in the mantle. As mentioned, all ${ }^{40} \mathrm{Ar}$ has been produced from the decay of ${ }^{40} \mathrm{~K}$ over time. Based on $\mathrm{U} / \mathrm{K}$ ratios, the $\mathrm{K}$ concentration of the BSE is estimated at $280 \pm 120 \mathrm{ppm}$ (Arevalo et al. 2009). Given a known decay rate of ${ }^{40} \mathrm{~K}\left(\lambda=5.55 \times 10^{-10} \mathrm{yr}^{-1}\right)$, the proportion of this decay which produces ${ }^{40} \mathrm{Ar}(10.72 \%)$, and the abundance of ${ }^{40} \mathrm{~K}(0.0117 \%)$ (Haynes et al. 2014), we calculate that a total of $4.2 \pm 1.8 \times 10^{18} \mathrm{~mol}{ }^{40} \mathrm{Ar}$ has been created over Earth history. Subtracting ${ }^{40} \mathrm{Ar}$ in the atmosphere $\left(1.65 \times 10^{18} \mathrm{~mol}\right)$ and continental crust $\left(0.35 \times 10^{18} \mathrm{~mol}\right.$, Arevalo et al. (2009) $)$ gives the ${ }^{40} \mathrm{Ar}$ content of the mantle to be $2.2 \pm 1.8 \times 10^{18} \mathrm{~mol}$.

Next, we observe that the $\mathrm{N}_{2}$ and ${ }^{40} \mathrm{Ar}$ data fall into two populations (Fig. 9): one containing MORB, some OIB, and some xenoliths with $\mathrm{N}_{2} /{ }^{40} \mathrm{Ar}$ values around $10^{2}$, which we coin as MORB-source like (MSL); and one containing some OIB and xenoliths with $\mathrm{N}_{2} /{ }^{40} \mathrm{Ar}$ around $10^{4}$, which we coin high-N. Interestingly, the MORB samples fall along a coherent trend with air at one end, as seen in previous work (Marty, 1995). Perhaps this indicates that the atmospheric $\mathrm{N}$ and Ar composition is the result of degassing the MORB-source mantle over time. In addition, the correlation between $\mathrm{N}_{2}$ and ${ }^{40} \mathrm{Ar}$ in the MORB, with weak correlation between $\mathrm{N}_{2}$ and ${ }^{36} \mathrm{Ar}$ over the same range, indicates that $\mathrm{N}$ has been cycled through the mantle; by proxy, it correlates with $\mathrm{K}^{+}$, which is concentrated in the continental crust, so observing a signal of K-input suggests contribution of continental material (Marty, 1995).

In contrast, OIB and xenolith data appear to describe a three-component mixture between air, a highMSL end-member, and an end-member composition with high $\mathrm{N}_{2}$ compared to ${ }^{40} \mathrm{Ar}$ (Fig. 9). Although the high-N field has only two OIB samples, we suggest it is a robust feature of the mantle as it is also defined by OIB-associated xenoliths and other xenoliths. OIB-associated xenoliths are thought to represent OIB-source material on the basis of high ${ }^{3} \mathrm{He} /{ }^{4} \mathrm{He}$ (Mohapatra et al. 2009, and references therein). High-N xenoltih samples are metasomatized, more fertile mantle lithologies (i.e., lherzolite, harzburgite, wehrlite) from locations in Oman and Europe (Yokochi et al. 2009). In addition, MORB samples that fall off the MSL trend are analyses from the East Pacific Rise, which is thought to have a plume-like component Marty and Zimmermann, 1999), so may represent an intermediate between MSL and high-N mantle types.

To actually estimate $\mathrm{N}$ content in mantle source regions, we must determine the $\mathrm{N}_{2} /{ }^{40} \mathrm{Ar}$ ratio for MSL and high-N mantle (Fig. 91. This is straightforward for MSL, which is described by a well-defined trend, and has a value of $120 \pm 11$. This value is consistent with previous work $\left(\mathrm{N}_{2} / \mathrm{Ar}=124 \pm 6\right.$, from Marty and Zimmermann, 1999). Determining the high-N ratio is less straightforward, as it defines a more dispersed 

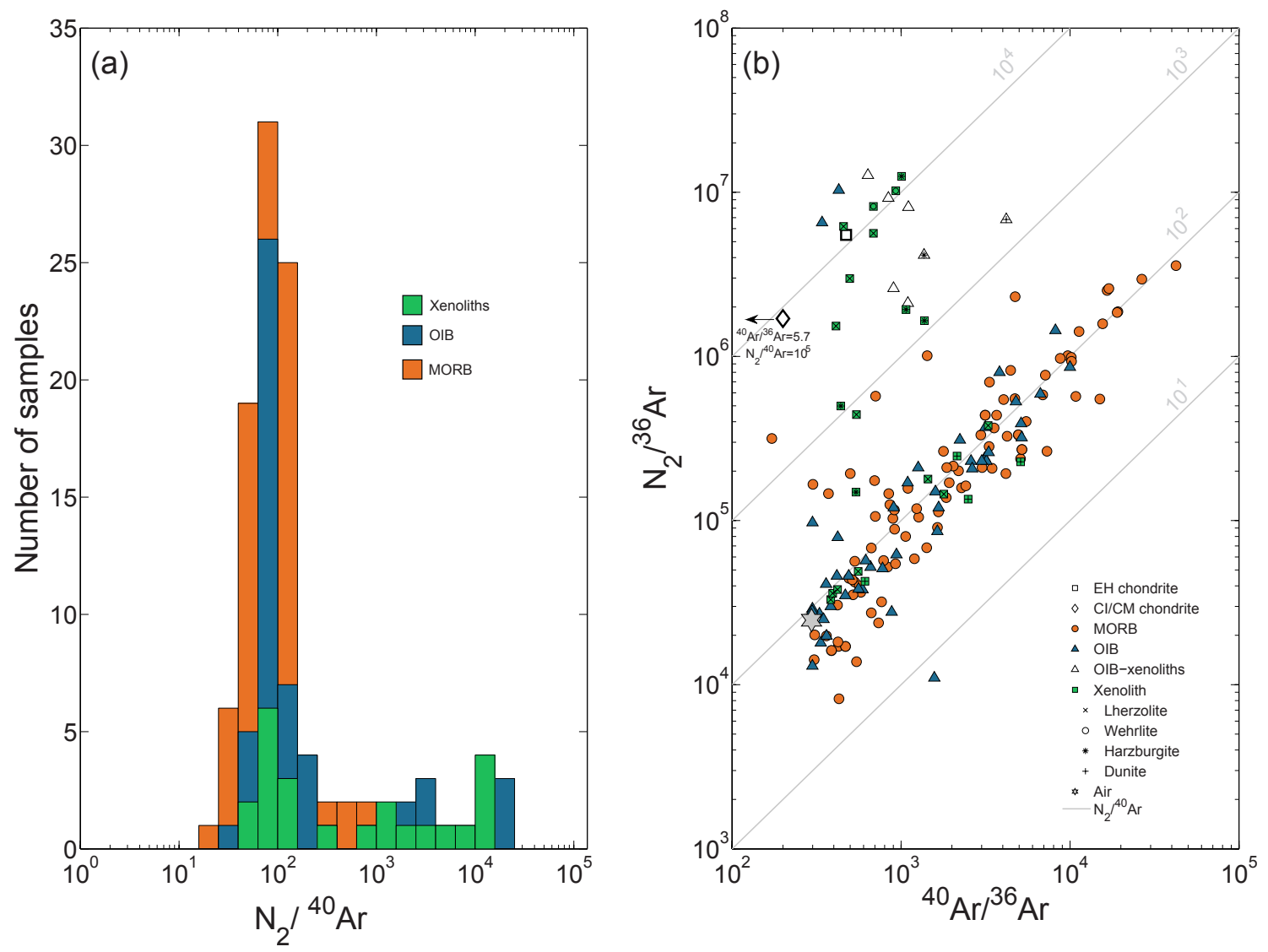

Figure 9: (a) $\mathrm{N}_{2}$ and Ar data showing log-normal distribution of $\mathrm{N}_{2} /{ }^{40} \mathrm{Ar}$ MORB (orange), OIB (blue), and xenolith (green) samples and (b) $\mathrm{N}_{2} /{ }^{36} \mathrm{Ar}$ as a function of ${ }^{40} \mathrm{Ar} /{ }^{36} \mathrm{Ar}$ for the same rocks. MORBs are shown in orange circles, OIB basalts in blue triangles, OIB-associated xenoliths in white triangles, and other xenoliths in green squares. Additional symbols indicate known xenolith rock type. MORB samples show clear correlation, confirming previous results (Marty 1995 . Marty and Zimmermann. 1999). OIB samples both overlap with MORB and define a distinct end-member. The existence of this nigh- $\mathrm{N}_{2} /{ }^{40} \mathrm{Ar}$ end member is corroborated by fertile xenolith samples. See text for discussion on the origin of this reservoir.

field. Since OIBs tend to record a somewhat more diverse set of mantle source types (White, 2010), we suggest that taking the average $\mathrm{N}_{2} /{ }^{40} \mathrm{Ar}$ ratio from all samples with $\mathrm{N}_{2} /{ }^{40} \mathrm{Ar}>10^{3}$ is the most appropriate approach to obtain a representative value. This ratio is $9.3 \pm 3.3 \times 10^{3}$. 


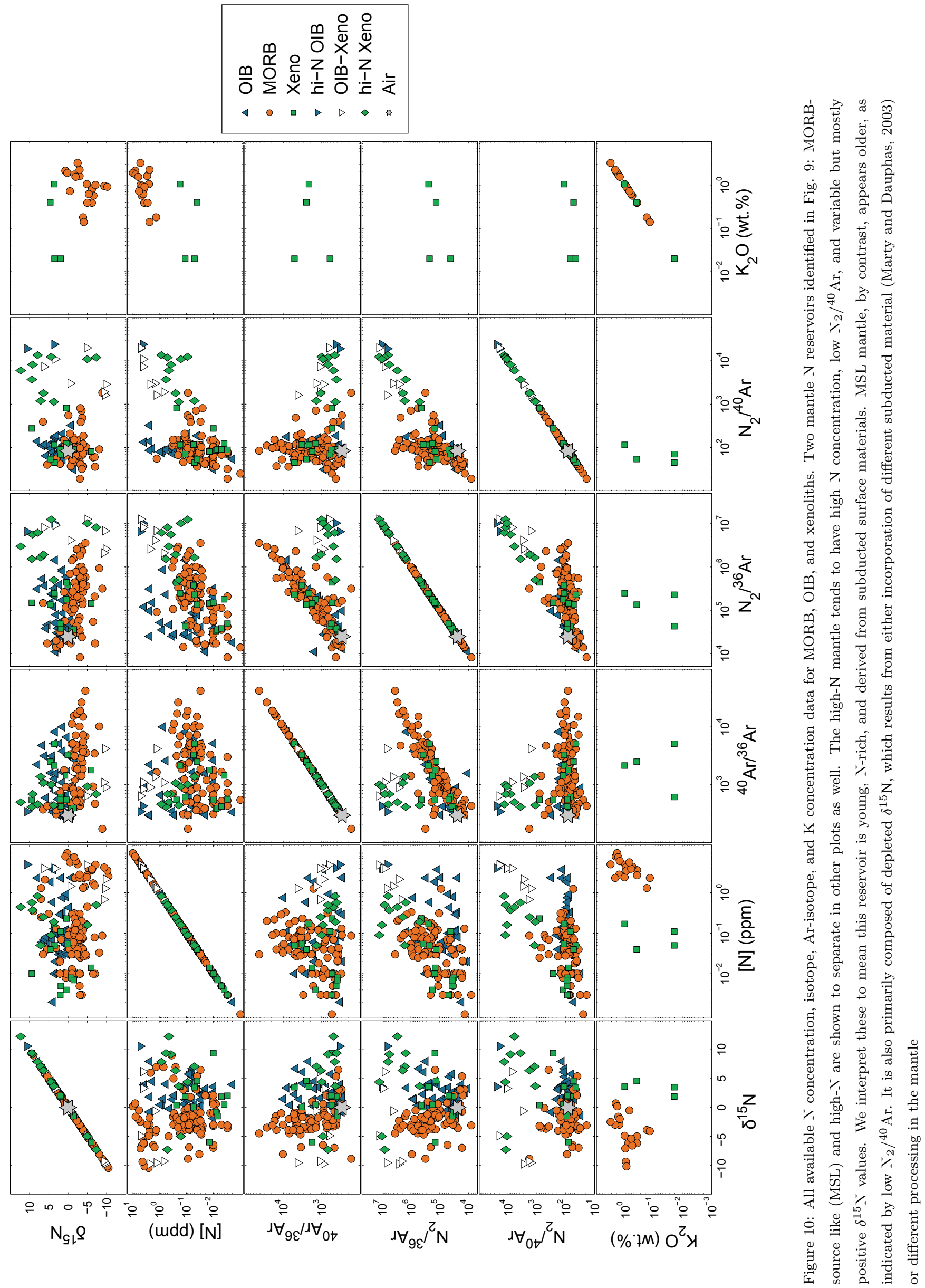


Table 10: Nitrogen and Ar isotope data for CC and EC, as shown in Fig. 9 CC data are from Marty (2012) and EC data from Hopp et al. (2014). We note that EC values are similar to our high-N mantle end member, while CC are not. This may be a coincidence, as $\mathrm{N}$ concentrations and $\delta^{15} \mathrm{~N}$ values of high- $\mathrm{N}$ mantle and $\mathrm{EC}$ are not equivalent.

\begin{tabular}{lcccc} 
Chondrite & $\mathbf{N}_{\mathbf{2}}\left(\mathbf{m o l ~ g} \mathbf{~ g}^{-1}\right)$ & $\mathbf{N}_{\mathbf{2}} /{ }^{36} \mathbf{A r}$ & ${ }^{40} \mathbf{A r} /{ }^{36} \mathbf{A r}$ & $\mathbf{N}_{\mathbf{2}} /{ }^{40} \mathbf{A r}$ \\
EC & $2.52 \pm 0.2 \times 10^{-5}$ & $5.5 \pm 0.4 \times 10^{6}$ & $473 \pm 10$ & $1.2 \pm 0.1 \times 10^{4}$ \\
CC & $4.4 \pm 0.1 \times 10^{-5}$ & $1.7 \pm 0.1 \times 10^{6}$ & $5.7 \pm 3.5$ & $3.1 \pm 1.3 \times 10^{5}$ \\
\hline
\end{tabular}

Now armed with ${ }^{40} \mathrm{Ar}$ abundance for the total mantle and $\mathrm{N}_{2} /{ }^{40} \mathrm{Ar}$ for MSL and high-N reservoirs, the last step required is to estimate the actual proportion of these types of mantle. This is the most difficult of the three criteria. Trace element (e.g., U, Ta) mass balance suggests estimate that the mantle is approximately $80 \%$ MORB-source composition and the remaining $20 \%$ is OIB-source composition (Workman and Hart, 2005 Arevalo et al. 2009, 2013). Determining what proportion of OIB-source mantle is high-N and what proportion is MSL is difficult, but crucially important to the overall estimate of $\mathrm{N}$ in the mantle. As a first attempt, we assume that analyzed OIB represent a statistical sampling of the OIB-source mantle. There are 9 OIB samples with high $\mathrm{N}_{2} /{ }^{40} \mathrm{Ar}\left(>10^{3}\right)$ out of 61 total OIB samples. This corresponds to high- $\mathrm{N}$ being $\sim 15 \%$ of the OIB-source mantle, or $3 \%(15 \% \times 20 \%)$ of the total mantle. If we assume uniform distribution of ${ }^{40} \mathrm{Ar}$ in the mantle, MSL (97\% of the total) has $2.13 \pm 1.7 \times 10^{18} \mathrm{~mol}{ }^{40} \mathrm{Ar}$ and the high-N mantle $(3 \%$ of the total) has $0.066 \pm 0.0054 \times 10^{18} \mathrm{~mol}{ }^{40} \mathrm{Ar}$. Given $\mathrm{N}_{2} /{ }^{40} \mathrm{Ar}$ mentioned above $(120 \pm 11$ for MSL and $9.3 \pm 3.3 \times 10^{3}$ for high-N), we calculate $\mathrm{N}$ mass in the MSL and high-N mantle to be $7.2 \pm 5.9 \times 10^{18}$ and $17 \pm 15 \times 10^{18} \mathrm{~kg} \mathrm{~N}$, respectively. Total mantle $\mathrm{N}$ is $24 \pm 16 \times 10^{18} \mathrm{~kg}$, which is equivalent to $6 \pm 4$ ppm N. While there is uncertainty in this estimate, primarily related to the $\mathrm{K}$ concentration estimate and distribution in the mantle, we suggest that our calculation represents a lower estimate. A larger proportion of high- $\mathrm{N}$ mantle would significantly increase a $\mathrm{N}$ mass estimate.

The most interesting and important aspect of our approach is the identification of two distinct mantle $\mathrm{N}$ reservoirs. The origin of both MSL and high-N components present a fascinating geochemical quandry. MSL mantle has low $\mathrm{N}_{2} /{ }^{40} \mathrm{Ar}$, low $\mathrm{N}$ concentration, but its $\delta^{15} \mathrm{~N}$ values describe two sub-populations: depleted $\delta^{15} \mathrm{~N}$ in MORB and enriched $\delta^{15} \mathrm{~N}$ in OIB (Fig. 10). Given the low $\mathrm{N}$ concentration $(<1 \mathrm{ppm}$ ) in most samples, the low $\mathrm{N}_{2} /{ }^{40} \mathrm{Ar}$ ratio should be caused by a high ${ }^{40} \mathrm{Ar}$ content resulting from significant time since this material (and by proxy K) was at the surface of the Earth. Subducted material with variable N and $\mathrm{K}$ contents would require a long time to acquire enough ${ }^{40} \mathrm{Ar}$ to push all samples towards a common trend. It therefore seems likely that MSL mantle is tapping a reservoir of older material derived from the surface. The $\delta^{15} \mathrm{~N}$ values are interesting, as MORB values of $-5 \%$ are distinct from modern subducted material, which is around +5 to $+7 \%$. OIB that fall along the MSL trend, however, show enriched $\delta^{15} \mathrm{~N}$ values, at $\sim 5 \%$. The difference either means that MORB and OIB in the MSL are tapping N reservoirs of subducted material that are different in space (Marty and Dauphas, 2003) but not in time (i.e., both tap old material) or that the way $\mathrm{N}$ is processed in the MORB-and OIB-source mantle or eruptions is different. It is difficult 
to discern between these options at this time, though future modelling and experimental work would aid in this pursuit.

The high- $\mathrm{N}$ mantle, in contrast, appears to be tapping relatively recently subducted surface material. This reservoir has high $\mathrm{N}_{2} /{ }^{40} \mathrm{Ar}$, high $\mathrm{N}$ concentration, and enriched $\delta^{15} \mathrm{~N}$ values in OIB and xenoliths (Fig. 10. High $\mathrm{N}$ concentration associated with high $\mathrm{N}_{2} /{ }^{40} \mathrm{Ar}$ implies this material is young, as it has not had sufficient time to accumulate ${ }^{40} \mathrm{Ar}$ through radioactive decay (Marty and Dauphas, 2003). The $\delta^{15} \mathrm{~N}$ values are also very close to modern, oceanic sedimentary values, at $7.1 \%$. Overall, the high- $\mathrm{N}$ mantle appears to be young, $\mathrm{N}$-rich, and received its $\mathrm{N}$ from subduction of surficial materials.

In detail, there are differences between high-N OIB, OIB-xenoliths, and xenoliths. While both OIB basalts and OIB-xenoliths have relatively high $\mathrm{N}$ content (4.5 and $2.7 \mathrm{ppm}$ ), they have distinct $\delta^{15} \mathrm{~N}$ values of $7.1 \%$ and $-3.5 \%$, respectively. Recall that the OIB-associated xenoliths are thought to represent the source rocks of coexisting OIBs. The difference in $\mathrm{N}$ isotopes could mean that $\mathrm{N}$ fractionates during partial melting, enriching the melt compared to the source. To our knowledge, there are no studies that quantify isotopic fractionation of $\mathrm{N}$ between partial melt and residual material in OIB genesis. If melt preferentially incorporates the heavy isotope, perhaps this could explain the observed relationship between OIB and their source. The remainder of the high- $\mathrm{N}$ xenolith population has enriched $\delta^{15} \mathrm{~N}$ values of $4.5 \pm 2 \%$ and low $\mathrm{N}$ concentration of $0.35 \pm 0.07 \mathrm{ppm}$.

An alternate approach to explain the high $\mathrm{N}_{2} /{ }^{40} \mathrm{Ar}$ ratio of the high- $\mathrm{N}$ mantle would be some process whereby $\mathrm{N}$ is retained preferentially to $\mathrm{K}$ during subduction and recycling. Such a process would concentrate $\mathrm{N}$ more in the mantle than $\mathrm{K}$, and therefore this material would have less ${ }^{40} \mathrm{Ar}$. It is possible that $\mathrm{K}$ is more mobile during subduction than $\mathrm{N}$. There are synthesized $\mathrm{NH}_{4}^{+}$-bearing micas (phengite), aluminosilicates (K-hollandite) (Watenphul et al., 2009) and clinopyroxenes (Watenphul et al., 2010) that are stable to eclogite-field conditions. As pyroxene is more stable at greater depth in the mantle, it is possible that storage of $\mathrm{N}_{\text {as }} \mathrm{NH}_{4}^{+}$in pyroxene allows for it to be more effectively retained than $\mathrm{K}$, whose host minerals (feldspars, micas) break down. Further experimental work concerning $\mathrm{N}$ and $\mathrm{K}$ behaviour during subduction could help address this issue. Discussed in some detail later, other locations that could fractionate $\mathrm{N}$ from $\mathrm{K}$ are the transition zone and lower mantle. In these reservoirs, metallic Fe is stable and $\mathrm{N}$ may be retained in this metal, while $\mathrm{K}$ is not. This is highly speculative, but further investigation of this high- $\mathrm{N}$ reservoir could help characterize the fate of volatiles in the mantle.

\subsubsection{Individual Mantle Domain Estimates}

An alternate approach to the Ar-based geochemistry is to attempt to break the mantle into different domains, and use measurements of xenoliths from those domains to estimate $\mathrm{N}$ mass. This approach may be more limited, due to relative paucity of analyzed samples as well as lack of material from the transition zone and lower mantle. Thus, we suggest the following be viewed as a minimum estimate. We will also only provide quantitative estimates for actual $\mathrm{N}$ content in domains that have been sampled, while for domains without direct samples we will discuss the capacity for $\mathrm{N}$ storage. 
We identify four sampled mantle reservoirs (Table 7): MORB-source, OIB-source, off-cratonic, and cratonic mantle. There are two reservoirs, the transition zone and lower mantle, that do not have $\mathrm{N}$ analyses from xenoliths (Fig. 8). Note this division is not intended to comment on chemical heterogeneity or stratification in the mantle, but merely to utilize different petrologic/geochemical proxies where appropriate to estimate the $\mathrm{N}$ content of the total mantle.

\subsubsection{MORB-source Mantle}

The amount of $\mathrm{N}$ in the MORB mantle is largely a function of the efficiency of degassing during mantle partial melting and MORB genesis. Melting under oxic conditions seems to be efficient at removing $\mathrm{N}$ from source rocks into magma (Libourel et al., 2003). Our data compilation of MORB-source mantle rocks (peridotite, harzburgite) suggests $\mathrm{N}$ content of $0.28 \pm 0.2 \mathrm{ppm}$ (Fig. 11). Using the same MORB-source mass abundance from the previous section ( $80 \%$ of the mantle) yields a $\mathrm{N}$ content for the MORB-source mantle of $0.74 \pm 0.1 \times 10^{18} \mathrm{~kg} \mathrm{~N}$. Note that experimental (Li et al., 2013) and theoretical (Mikhail and Sverjensky, 2014 ) work suggest that in the middle to lowermost upper mantle redox, pressure, and pH conditions may be consistent with the presence of $\mathrm{NH}_{3}$ or $\mathrm{NH}_{4}^{+}$. These molecules may be retained more effectively than $\mathrm{N}_{2}$, thus this portion of the mantle may be more $\mathrm{N}$ rich than indicated by xenoliths alone.

\subsubsection{OIB-source Mantle}

For this estimate, we turn to analyses of OIB as well as OIB-associated xenoliths as described in in section 4.5.1. These rocks have an average $\mathrm{N}$ concentration of $0.7 \pm 0.5$ and $2.7 \pm 0.8 \mathrm{ppm}$. Note that we include all OIB in this estimate, whereas in section 4.5.1 we identified two OIB-source reservoirs. In addition, OIB have likely experienced some degassing upon eruption, so this concentration should be viewed as a minimum. We assume that OIBs represent partial melts that melted under conditions conducive to quantitative $\mathrm{N}$ extraction from the source. Therefore, with $10 \%$ partial melt (Winter, 2001), source concentration would be $0.07 \pm 0.04 \mathrm{ppm} \mathrm{N}$. This is much lower than the OIB-xenolith values, but again should be viewed as a minimum. Given an OIB-source proportion of $20 \%$ yields a N mass of $0.06 \pm 0.04 \times 10^{18} \mathrm{~kg}$ for OIB based $\mathrm{N}$ concentration and $2.2 \pm 0.6 \times 10^{18} \mathrm{~kg}$ for OIB-xenolith based concentration.

Additionally, while degassing during eruption has likely occurred, it is worth noting that the concentration of $\mathrm{N}$ in OIBs is of the same order of magnitude as the concentration of $\mathrm{N}$ in carbonatites from the Kola peninsula, which are around $0.11 \mathrm{ppm}$ (Dauphas and Marty, 1999). The carbonatites are thought to be sourced from fairly deep, crystallized at depth, and to have experienced minimal degassing during

emplacement. Carbonatite magmas, however, are likely sourced from a mantle domain distinct from the OIB-source mantle. 

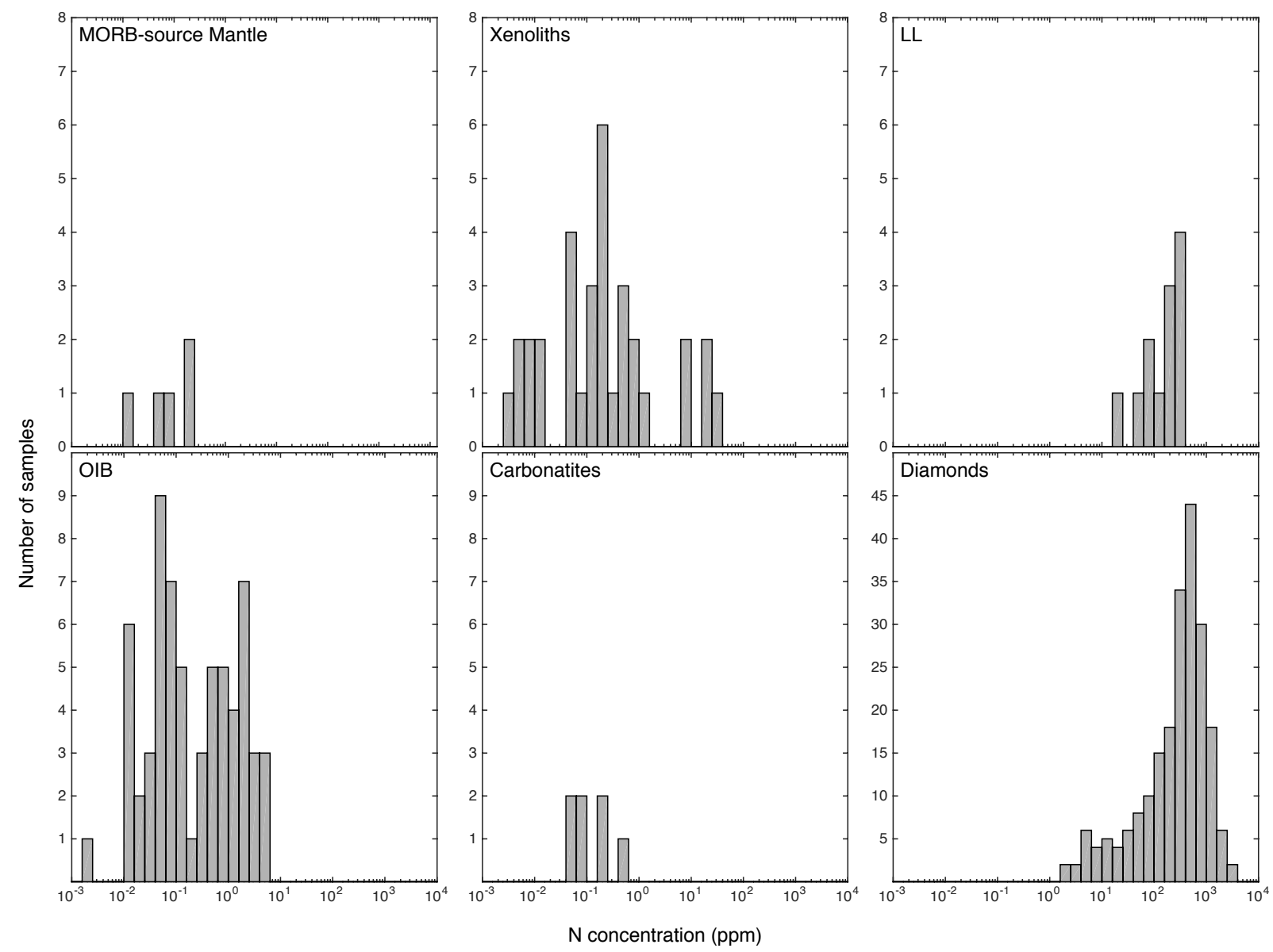

Figure 11: Nitrogen concentrations in mantle rocks, melts, and diamonds. While diamonds are well characterized, the number of analyses in other rock types are rare. MORB-source mantle samples include rocks from dredges and from ophiolites, while xenoliths are samples brought to the surface on continents. Lamproite and lamprophyre (LL) are thought to be sourced from hydrated mantle, and their high $\mathrm{N}$ concentration suggests effective recycling of $\mathrm{N}$ into this region of the mantle (Sec. 4.5.2.3. Ocean Island Basalts (OIB) are discussed in detail in Sec. 4.5.1 and carbonatites are presented simply as a comparison. See Dauphas and Marty (1999) for a discussion of these samples. 


\subsubsection{Off-cratonic Upper Mantle}

The sub-continental mantle can be broken into two domains: off-cratonic mantle, which has been influenced by Phanerozoic subduction and cratonic mantle, which is the stable mantle underneath cratons. We discuss the off-cratonic mantle first.

Off-cratonic mantle is roughly equivalent to the mantle wedge associated with subduction zones. Since mass balance studies suggest the majority of subducted $\mathrm{N}$ does not return to the atmosphere via arc magmatism (Mitchell et al. 2010: Busigny et al. 2011), it is possible that some of this $\mathrm{N}$ is retained in this reservoir. We invoke analyses of specific alkaline volcanic rocks, lamprophyres and lamproites (LL), as proxy for mantle influenced by subduction. These rocks, though volumetrically small, are geographically widespread (Winter, 2001), which indicates their potential as a useful proxy.

Petrogenetic analysis of LL suggests that they are sourced from hydrated mantle composed of phlogopite (mica)-bearing harzburgite (Tainton and McKenzie, 1994 Mitchell, 1995), though some may be sourced from deeper in the mantle (Murphy et al. 2002). Phlogopite harzburgite may be produced via a two step process: an initial mantle melting event, and the subsequent addition of fluids sourced from subducted continental/marine sediments. Later partial melting $(1-10 \%)$ of the harzburgite produces LL magmas.

A suite of LL from India have N concentrations that range from 21-394 ppm (Jia et al., 2003), with an average of $210 \pm 60 \mathrm{ppm}$ (Fig. 11). The corresponding $\mathrm{N}$ content of the mantle source of LL depends, then, on the behaviour of $\mathrm{NH}_{4}^{+}$during melting.

The Rare Earth Element (REE) profiles of the Indian LL may both constrain the compatibility of $\mathrm{N}$ in the source rock and could perhaps be used as a proxy for $\mathrm{N}$ in other samples where $\mathrm{N}$ was not measured explicitly. Ytterbium and Lu show a significant correlation with $\mathrm{N}$ (when disregarding a sample with high, $400 \mathrm{ppm}, \mathrm{N}$ ), with $\mathrm{r}^{2}$ values of 0.70 and 0.79 , respectively (Fig. 12. This suggests that $\mathrm{N}$, Yb, and Lu behave similarly during LL formation.

The behaviour of $\mathrm{Yb}$ and $\mathrm{Lu}$ during $\mathrm{LL}$ formation is relatively well known, as $\mathrm{K}_{\mathrm{D}}$ values have been measured in minerals experimentally (Table 11). We use these mineral $\mathrm{K}_{\mathrm{D}}$ values to calculate a bulk $\mathrm{K}_{\mathrm{D}}$ value, which is a simple weighted average, for a phlogopite-harzburgite source rock with $60 \%$ olivine, $30 \%$ pyroxene, and 10\% phlogopite. Bulk $\mathrm{K}_{\mathrm{D}}$ are 0.0505-0.0979 for $\mathrm{Yb}$ and 0.0636 for Lu (Fujimaki et al., 1984. Foley and Jenner, 2004).

The $\mathrm{K}_{\mathrm{D}}$ of $\mathrm{N}$ has not been measured during LL formation, to our knowledge, so as a first approximation we will assume that it is equal to the $\mathrm{K}_{\mathrm{D}}$ of $\mathrm{Yb}$ or $\mathrm{Lu}$, based on the strong correlation shown in Fig. 12. Using Equation 7, we calculate a $\mathrm{N}$ concentration in LL source of $35 \pm 7 \mathrm{ppm}$ based on $\mathrm{Yb}$ and $33 \pm 9 \mathrm{ppm}$ based on Lu for $10 \%$ partial melting. Assuming 1\% partial melting gives $\mathrm{N}$ concentration of $18 \pm 4 \mathrm{ppm}$ based on $\mathrm{Yb}$ and $15 \pm 5 \mathrm{ppm}$ based on Lu. Correspondingly, the mass of $\mathrm{N}$ would be between $1.4 \times 10^{18}$ and $3.4 \times 10^{18}$ $\mathrm{kg}$. 


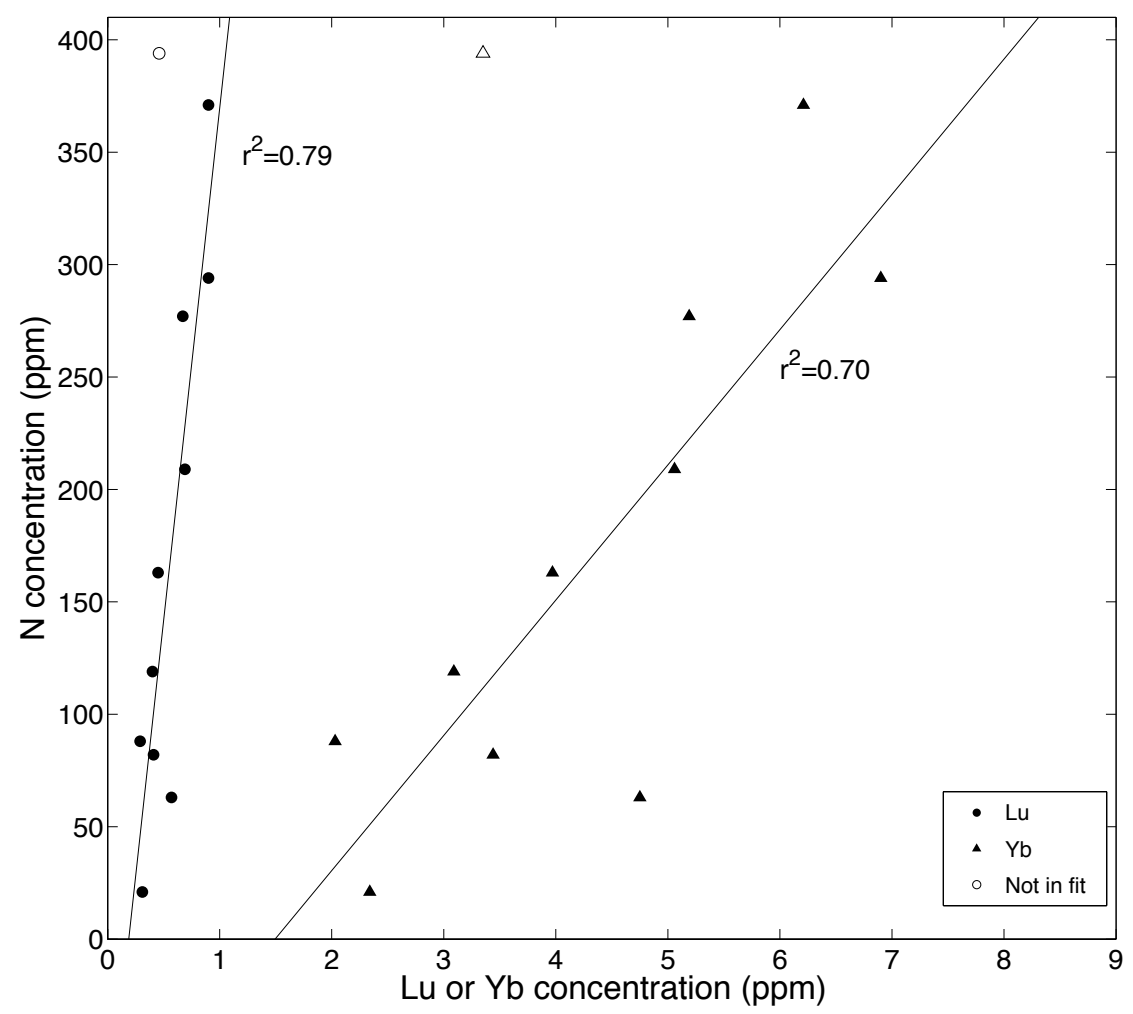

Figure 12: Nitrogen and Lu or Yb concentration in lamproites/lamprophyres (LL) from Jia et al. (2003). Significant correlation suggests these elements behave similarly during melting, and we use this observation as an estimate for the $\mathrm{N}$ content of the off-cratonic upper mantle. Empty symbols were not included in regression. 
Table 11: Partition coefficients of $\mathrm{Yb}$ and $\mathrm{Lu}$ in lamproite/lamprophyre (LL). $\mathrm{K}_{\mathrm{D}}$ values shown are for a LL source rock that is $60 \%$ olivine, $30 \%$ pyroxene, and $10 \%$ phlogopite.

\begin{tabular}{|c|c|c|c|c|}
\hline \multicolumn{3}{|c|}{$\mathbf{K}_{\mathbf{D}}$} & \multirow{2}{*}{\multicolumn{2}{|c|}{ Reference }} \\
\hline Mineral & $\mathrm{Yb}$ & $\mathrm{Lu}$ & & \\
\hline Olivine & 0.0091 & 0.0187 & Foley and Jenner & $(2004)$ \\
\hline Pyroxene & $0.134-0.292$ & 0.159 & Foley and Jenner & $(2004)$ \\
\hline Phlogopite & 0.0484 & 0.0471 & Fujimaki et al. & $(1984)$ \\
\hline Bulk rock & $0.0505-0.0979$ & 0.0636 & & \\
\hline
\end{tabular}

Table 12: Nitrogen concentration and total mass estimates in the off-cratonic mantle based on analysis of lamproite/lamprophyre $(\mathrm{LL})$ and $\mathrm{K}_{\mathrm{D}}$ values of $\mathrm{Yb}$ and $\mathrm{Lu}$ (Table 11. Nitrogen behaviour is assumed to be similar to $\mathrm{Yb}$ and Lu (Fig. 12, and bulk $\mathrm{K}_{\mathrm{D}}$ values are then used to estimate $\mathrm{N}$ mass $\left(10^{18} \mathrm{~kg}\right)$ using Eq. 7 . We present estimates for 1 and $10 \%$ melt.

\begin{tabular}{ccccc} 
& \multicolumn{2}{c}{ N concentration $(\mathrm{ppm})$} & \multicolumn{2}{c}{$\mathrm{N}$ mass $\left(10^{18} \mathrm{~kg}\right)$} \\
Melt & Yb-based & Lu-based & Yb-based & Lu-based \\
$10 \%$ & $35 \pm 7$ & $33 \pm 9$ & $3.4 \pm 0.7$ & $3.2 \pm 0.8$ \\
$1 \%$ & $18 \pm 4$ & $15 \pm 5$ & $1.7 \pm 0.5$ & $1.4 \pm 0.5$ \\
\hline
\end{tabular}

\subsubsection{Cratonic Mantle}

We draw upon three data sources to calculate the $\mathrm{N}$ content of the cratonic upper mantle: xenoliths, diamond analyses, and experimental petrology. Xenolith data gives rather different results than the estimate combining diamond and experimental data. We suggest that these approaches provide lower (xenolith) and upper (diamonds plus experiments) limits on the $\mathrm{N}$ content of the cratonic mantle.

Xenolith $\mathrm{N}$ concentration is $0.28 \pm 0.2 \mathrm{ppm}$. If these are representative of cratonic mantle, this reservoir has very low $\mathrm{N}$ mass, of $0.04 \pm 0.03 \times 10^{18} \mathrm{~kg}$. There are very few analyses of $\mathrm{N}$ in xenoliths, thus it is difficult to say how representative they are.

A second approach is to use the much more plentiful literature database for $\mathrm{N}$ analyses in diamonds. The majority of diamonds are formed in the cratonic lithosphere (Cartigny, 2005: Stachel and Harris, 2009), thus they should be able to reveal information about this reservoir. First, we calculate the average $\mathrm{N}$ content of diamonds to be $740 \pm 176$ (Fig. 11). Diamonds form via precipitation from a fluid, so the next step is to estimate how much $\mathrm{N}$ remains in the fluid after diamond formation, and to assess the ability of the host rocks to absorb this extra $\mathrm{N}$. A $\mathrm{K}_{\mathrm{D}}$ between $\mathrm{N}$ in diamond and $\mathrm{N}$ remaining in the diamond-forming fluid of 4 has been suggested based on study of the Jericho Kimberlite, in the Slave Craton of Canada (Smart et al., 2011). Thus, given a $\mathrm{K}_{\mathrm{D}}$ of $4, \mathrm{~N}$ concentration in residual diamond-forming fluid is $185 \pm 44 \mathrm{ppm}$. 
Next, using experimental results, we calculate the capacity of the sub-cratonic lithosphere to retain $\mathrm{N}$ left in diamond-forming fluid after diamond formation (Eqs. 445). P-T- $f_{\mathrm{O}_{2}}$ conditions appropriate to the sub-cratonic lithosphere are: $\mathrm{T}=1400^{\circ} \mathrm{C}, \mathrm{P}=6 \mathrm{GPa}$, and $f_{\mathrm{O}_{2}}=\mathrm{FMQ}-4(\Delta \mathrm{NiNiO}=-2.3)$ (Frost and McCammon, 2008). Hence, we calculate a N capacity of $120 \mathrm{ppm}$ for pyroxene and $5 \mathrm{ppm}$ for olivine. If we assume a harzburgite-like composition (70\% olivine, 30\% pyroxene) (Lee et al., 2011), a total N capacity of $40 \mathrm{ppm}$ is calculated. If portions of the mantle are more fertile (i.e., higher pyroxene content) they would have correspondingly a higher $\mathrm{N}$ capacity. Analyses of $\mathrm{N}$ in natural olivine and pyroxene are much lower $(<1 \mathrm{ppm}$, Yokochi et al. (2009) ) than this calculated upper limit, implying the actual content may be significantly lower than the capacity.

The capacity of upper mantle minerals is consistent with relatively high $(\sim 40 \mathrm{ppm}) \mathrm{N}$ contents. We suggest that $\mathrm{N}$ remaining in diamond-forming fluid after diamond formation may be effectively sequestered in the sub-cratonic lithosphere. In addition, $\mathrm{N}$ concentration in the $10 \mathrm{~s}$ of ppm is corroborated by estimates of $\mathrm{C} / \mathrm{N}$ based on diamond analyses (Cartigny et al. 2001). A $\mathrm{N}$ concentration of $40 \mathrm{ppm}$ yields a $\mathrm{N}$ mass of $\sim 5.6 \times 10^{18} \mathrm{~kg}$. This is likely an upper estimate, as it assumes all cratonic mantle was infiltrated by diamond-forming fluids and that all $\mathrm{N}$ not included in diamonds was retained in the host rock. Uncertainty in the extent of diamond-forming fluid (if this is the source of $\mathrm{N}$ ) introduces error to this estimate, though if experimental relationships accurately describe the $\mathrm{N}$ solubility in upper mantle minerals there is no issue with storage capacity.

Additional uncertainty may result from disagreement concerning the compatibility of $\mathrm{N}$ during diamond growth. An extensive compilation by Cartigny et al. (2001) suggests that the incorporation of $\mathrm{N}$ into diamonds from diamond-forming fluids is a kinetic process: slow diamond growth results in low $\mathrm{N}$ content. Both measurements of Slave Craton diamonds (Smart et al., 2011) and synthetic diamonds suggest that $\mathrm{N}$ behaves compatibly (Stachel and Harris, 2009). The majority of diamonds with depleted $\delta^{13} \mathrm{C}$ values that are indicative of a recycled crustal input do not have commensurate enriched $\delta^{15} \mathrm{~N}$ values (Cartigny, 2005), which would be expected if the source of $\mathrm{N}$ and $\mathrm{C}$ was subducted oceanic material. This either indicates that recycled material that was incorporated into diamond growth had different $\delta^{15} \mathrm{~N}$ values from modern surface reservoirs (Marty and Dauphas, 2003) or that $\mathrm{C}$ and $\mathrm{N}$ incorporation into diamonds is decoupled/depends only on growth rate (Cartigny et al., 2001).

\subsubsection{Transition Zone}

The transition zone (TZ) is the region in the mantle between 410 and $660 \mathrm{~km}$ depth, and is defined by mineral phase changes. At $410 \mathrm{~km}$, olivine changes its structure to the more tightly packed spinel-like crystal lattice of wadsleyite then ringwoodite. Below $660 \mathrm{~km}$, another phase change occurs, and the spinel-structure mineral changes to bridgmanite, a high-pressure polymorph. These phase changes control redox chemistry, and the $\mathrm{TZ}$ is more reducing than the overlying upper mantle. The $f_{\mathrm{O}_{2}}$ here is around IW-1, and both experiments and calculations suggest the presence of 0.1 wt.\% metallic Fe (Frost and McCammon, 2008) in this region. 
Therefore, with 0.1-2 wt.\% N dissolved (Kadik et al., 2011; Roskosz et al., 2013) in 0.1 wt.\% metallic Fe (Frost and McCammon, 2008), N concentration would be 100-2000 ppm. This represents the N capacity of the transition zone, with a strong upper bound between $48 \times 10^{18}$ to $960 \times 10^{18} \mathrm{~kg} \mathrm{~N}$. The high N potential of the transition zone, and indeed the lower mantle, was recently suggested based on the observation that the more deeply diamonds form, the less $\mathrm{N}$ they contain (Smith et al. 2014). The authors suggest that the low-N diamonds grew in the presence of Fe-metal, which preferentially dissolved N. This is consistent with our literature review.

Sequestering $\mathrm{N}$ in the transition zone for significant periods of time may be difficult, however. Whole mantle circulation means that material in the transition zone does not stay there (e.g., Nakagawa and Tackley, 2012). Both the upper mantle and lower mantle are more oxidizing that the TZ (Frost and McCammon. 2008). Thus, when material moves out of the TZ, previously metal-bound $\mathrm{N}$ may be released into either fluids or minerals. This may preclude long-term N storage in the TZ. Without further evidence (petrologic or experimental), the transition zone remains a hypothetical reservoir for N. It is not considered in our total $\mathrm{N}$ estimates for the Earth.

\subsubsection{Lower Mantle}

The lower mantle, which is defined by the phase transition at $660 \mathrm{~km}$ depth described above, is not represented by xenoliths or inclusions in our $\mathrm{N}$ database. We are unaware of any such analyses. As with the transition zone, we may only be able to speak to the storage capacity of this portion of the mantle.

There is speculation that 1 wt.\% metallic Fe may exist in the lower mantle (Frost et al., 2004). High

pressure/temperature experimental petrology demonstrates that $\mathrm{N}$ is quite soluble in metallic Fe at these conditions, with up to 8 wt.\% (Roskosz et al., 2013). Given a mantle with these proportions of Fe-metal and $\mathrm{N}$ solubility suggests a $\mathrm{N}$ capacity of $2.3 \times 10^{23} \mathrm{~kg} \mathrm{~N}$. This value is orders of magnitude higher than any other reservoir in the planet, perhaps save the core. As with the transition zone, this is highly speculative, and would require further confirmation via geochemical or modelling study.

If there are regions of the lower mantle that remain shielded from mantle convection and mixing, they may represent a location for storage of the Earth's "missing N". That is, the abundance of N compared to other volatiles in the BSE was previously estimated to be about an order of magnitude lower (Marty, 2012). The lower mantle has more than enough capacity to store additional N. If, however, our Ar-based estimate for $\mathrm{N}$ abundance in the mantle is correct, there is no need to invoke hidden reservoirs of $\mathrm{N}$, as we calculate mantle $\mathrm{N}$ mass in line with other volatile abundances.

\section{Discussion}

We find that our two methods for calculating the N budget of the Bulk Silicate Earth (BSE) are consistent. Both comparison to chondrite N abundance ("top-down") and compilation of terrestrial analyses ("bottom-

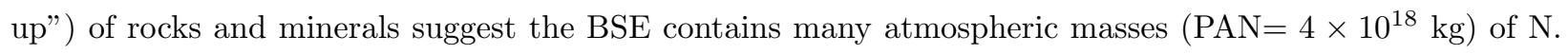


Table 13: BSE N masses, shown in $10^{18} \mathrm{~kg} \mathrm{~N}$. When adding oceanic crust into totals, the range $(0.16 \pm 0.01$ to $0.26 \pm 0.02)$ was averaged to $0.21 \pm 0.01$. The approach column notates which method: literature compilation (LC) or Ar-based geochemistry (AR). The preferred value total is shown in bold. The AR approach for the mantle is preferred, because it more likely "samples" a greater extent of the mantle than xenoliths. Results are presented with comparison to Goldblatt et al. (2009) (CG).

\begin{tabular}{|c|c|c|c|c|}
\hline Reservoir & Location & This study & Approach & CG \\
\hline \multirow[t]{2}{*}{ Oceanic Lithosphere } & Sediments & $0.41 \pm 0.2$ & $\mathrm{LC}$ & $0.31 \pm 0.16$ \\
\hline & Crust+Mantle & $0.16 \pm 0.01$ to $0.26 \pm 0.02$ & $\mathrm{LC}$ & $0.012 \pm 0.005$ \\
\hline \multirow[t]{3}{*}{ Continental Crust } & Igneous & & & $0.55 \pm 0.27$ \\
\hline & Sedimentary & & & $1.55 \pm 0.62$ \\
\hline & Total & $1.7 \pm 0.1$ & $\mathrm{LC}$ & $2.1 \pm 1.05$ \\
\hline \multirow[t]{6}{*}{ Mantle } & MORB-Source & $1.2 \pm 0.8$ & $\mathrm{LC}$ & \\
\hline & OIB-source & $>0.06 \pm 0.04$ to $2.2 \pm 0.6$ & $\mathrm{LC}$ & \\
\hline & Off-cratonic & 1.4 to 3.4 & $\mathrm{LC}$ & \\
\hline & cratonic & $<5.6$ & $\mathrm{LC}$ & \\
\hline & transition zone, lower & $<100$ & & \\
\hline & Total & $>3.4 \pm 1.3-5.8 \pm 1.4$ & $\mathrm{LC}$ & \\
\hline \multirow[t]{3}{*}{ Mantle } & MORB-source-like Mantle & $7.2 \pm 5.9$ & $\mathrm{AR}$ & \\
\hline & high-N & $17 \pm 15$ & $\mathrm{AR}$ & \\
\hline & Total & $24.2 \pm 16$ & $\mathrm{AR}$ & $\geq 8.4 \pm 5.2$ \\
\hline BSE Total & LC Crusts and LC Mantle & $>5.7 \pm 1.3-8.1 \pm 1.4$ & & \\
\hline BSE Total & LC Crusts and AR Mantle & $27 \pm 16$ & & $10.8 \pm 5.3$ \\
\hline
\end{tabular}


The chondritic comparison suggests between $17 \pm 13 \times 10^{18}$ and $31 \pm 24 \times 10^{18} \mathrm{~kg} \mathrm{~N}$ are in BSE while the terrestrial literature compilation suggests $27 \pm 16 \times 10^{18} \mathrm{~kg} \mathrm{~N}$. Both estimates also have theoretical upper limits that are much higher (Table 13, due to increased solubility of $\mathrm{N}$ in silicates at depth. This close agreement shows that our budget is internally self-consistent. It may also remove the concept of "missing N" (e.g., Marty, 2012, Halliday, 2013), as the mantle appears to have ample capacity for N sequestration.

Importantly, our estimate is higher than previous estimates (e.g., Goldblatt et al., 2009). The mantle appears to have a significant portion of the planetary $\mathrm{N}$ budget. High $\mathrm{N}$ content in the BSE has significant ramifications in relation to Earth and atmospheric geochemistry.

\subsection{Key uncertainties}

Before discussing geochemical implications of the new budget presented herein, we touch briefly on the main uncertainties in our estimate. First, sparsely analyzed reservoirs (specifically the mantle and lower continental crust) inherently limit accuracy in estimates. Further analysis of these important reservoirs should be a focus of future work. Second, though the behaviour and partitioning of $\mathrm{N}$ during melting in the mantle is beginning to be tested experimentally (e.g., Libourel et al., 2003, Mysen and Fogel, 2010, Li et al. 2013, 2015), the relative lack of studies necessarily introduces uncertainty. We suggest that $\mathrm{N}$ behaves similarly to $\mathrm{Lu}$ and $\mathrm{Yb}$, though this relationship has not been assessed in all rock types. It is becoming clear that $f_{\mathrm{O}_{2}}$, temperature, and pressure all exert strong control over $\mathrm{N}$ contents in the mantle. More experimental petrology and modelling studies would be valuable in elucidating the behaviour of $\mathrm{N}$ at the range of conditions found in the solid Earth.

Thirdly, determining the geochemical character of the high-N mantle reservoir identified in Section 4.5.1 more accurately is of crucial importance. This reservoir, despite its small mass, may contain the majority of the $\mathrm{N}$ in the mantle. As it appears to be sampled by some OIB and xenoliths, more coupled N-Ar measurements of these rocks should help define this end member more completely. The stable isotopes are consistent with a recycled component, but the extent, residence time, and other geochemical properties are not fully constrained at this time.

\subsection{Evolution of the atmosphere-mantle system}

The atmosphere is not the main reservoir for $\mathrm{N}$ on Earth today. However, the processes responsible for the current distribution are not fully resolved. It remains ambiguous if the distribution between BSE and atmosphere has been the same as the current state, or if it has been different in the past. Nitrogen isotopic evidence and correlation with radiogenic ${ }^{40} \mathrm{Ar}$ indicates that $\mathrm{N}$ derived from the surface of the Earth is subducted and cycled into the BSE (e.g., Marty, 1995, Marty and Dauphas, 2003; Palya et al., 2011), so exchange has clearly occurred. The setting where this input occurs is subduction zones. At current subduction rates, $9.3 \times 10^{18} \mathrm{~kg} \mathrm{~N}$ could be subducted over 4 Ga of Earth history (Sec. 4.4.2). So at modern subduction rates, consistent since at least the Cretaceous (Busigny et al. 2011), the entire atmosphere could be potentially pass through the mantle if $\sim 50 \%$ of subducted $\mathrm{N}$ is recycled to the mantle (i.e., not returned 
to the atmosphere). This retention efficiency at modern subduction zones is poorly constrained (Halama et al. 2012), with the Central American margin appearing to return significant sedimentary N (100\%) to the atmosphere (Elkins et al. 2006) while the colder Izu-Bonin-Mariana Arc retains most of subducted N $(\sim 85 \%)$ to mantle depth (Mitchell et al. 2010). As such, there is no reason to rule out different efficiency in the past.

There are two reasons to suggest that $\mathrm{N}$ subduction was more efficient in the past. The first is that prior to the Great Oxidation Event, it is likely that the dominant $\mathrm{N}$ ion in the oceans was $\mathrm{NH}_{4}^{+}$Garvin et al. 2009). Since $\mathrm{NH}_{4}^{+}$substitutes into sediments and oceanic lithosphere to enter the geologic cycle, a higher concentration might promote a greater $\mathrm{N}$ flux into subducting sediments and lithosphere. Indeed, an increase in $\mathrm{N}$ concentration is seen in Black Sea samples in the Quaternary, with sediments deposited under anoxic conditions having about twice as much $\mathrm{N}$ as sediments deposited under oxic conditions (Quan et al. 2013b). Additionally, higher mantle temperature in the Archean (e.g., Herzberg et al., 2010) has been interpreted to lead to more vigorous mantle convection. Hotter mantle is also thought to produce thicker oceanic crust, due to greater degree of partial melting. Higher heat flow should cause extensive hydrothermal alteration, which could act as a sink for $\mathrm{NH}_{4}^{+}$from the ocean. A hotter mantle, however, may also be a drier mantle Korenaga, 2011; Sandu et al., 2011), which would tend to slow convection and subduction. The interplay between these two factors, increased $\mathrm{NH}_{4}^{+}$in the ocean and crust and hotter mantle, and any effects on $\mathrm{N}$ subduction are not known.

Progressive $\mathrm{N}$ sequestration over time implies a more massive atmosphere in the Archean, which has potentially important effects on greenhouse warming (Goldblatt et al., 2009, Byrne and Goldblatt, 2014). Independent proxies for Archean paleopressure based on fossil raindrops (Som et al., 2012) and hydrothermal inclusions in quartz grains (Marty et al. 2013), however, suggest the Archean atmosphere had the same amount (or less) of $\mathrm{N}$ as the modern. The raindrop constraint has subsequently been found to be too low; a more realistic constraint here is up to ten times modern density (Kavanagh and Goldblatt, 2015). The $\mathrm{N}_{2} /{ }^{36} \mathrm{Ar}$ ratio from 3.0 Ga hydrothermal inclusions in quartz grains are approximately equal to the modern value (Marty et al., 2013); this is inferred to suggest that the atmosphere may have had the same pressure (and therefore $\mathrm{N}$ content) as the modern day Earth. An earlier study on the same grains suggests, however, an upper limit for the $\mathrm{N}_{2} /{ }^{36} \mathrm{Ar}$ of 3.3 times the modern value (Nishizawa et al. 2007). A robust empirical constraint on the amount of $\mathrm{N}_{2}$ in the Archean atmosphere is enigmatic at this time. Our work indicates substantial $\mathrm{N}$ is in the mantle, at least some of which has been recycled from the surface, so it is possible that the atmosphere was more massive in the past. Whether this indicates a monatonic drawdown or some more dynamic evolution of the atmosphere-mantle system is unknown at this time.

The fate of subducted $\mathrm{N}$ has a direct effect on the $\delta^{15} \mathrm{~N}$ value of the mantle. In fact, a significant missing piece of the $\mathrm{N}$ puzzle is the origin of the depleted $\delta^{15} \mathrm{~N}$ signature of the MORB-source mantle, which exists in an apparent disequilibrium with isotopically enriched surface reservoirs. As briefly discussed in Sec. 4.5.1. there appear to be two classes of solutions to this dilemma: the MORB-source mantle records early 
subduction of depleted N (Marty and Dauphas, 2003) or that fractionations of N isotopes during deep Earth transport are responsible. A distinct MORB-only source mantle is not supported by our compilation herein, as many OIB have equivalent $\mathrm{N}_{2} /{ }^{40} \mathrm{Ar}$ values as MORB. However, MORB and OIB have different $\delta^{15} \mathrm{~N}$ values at $-5 \%$ and $>0 \%$, respectively, so there must be some process to explain this distinction. Possibly they represent pools of different subducted material that has "aged" the same amount to yield equivalent $\mathrm{N}_{2} /{ }^{40} \mathrm{Ar}$. Preservation of distinct $\delta^{15} \mathrm{~N}$ values implies incomplete mantle mixing over time. The existence of the high-N mantle supports the existence of different mantle domains, though we cannot rule out that the different $\mathrm{N}_{2} /{ }^{40} \mathrm{Ar}$ signature of the high- $\mathrm{N}$ reservoir could be caused by fractionation of $\mathrm{N}$ from during subduction or deeper mantle processing. Redox reactions and possible $\mathrm{N}$ sequestration in the transition zone and lower mantle may all affect $\mathrm{N}$ geochemical signatures of mantle and mantle melts.

It is becoming apparent through experimental (Li et al., 2013) and theoretical (Mikhail and Sverjensky, 2014 ) that $\mathrm{NH}_{4}^{+}$is the predominant species of $\mathrm{N}$ in much of the mantle. The geochemical behaviour of $\mathrm{NH}_{4}^{+}$ in subduction zones and mantle reservoir materials (e.g., silicates, Fe-metal) should be a target for future research, as any isotopic fractionations are unknown to us at this time.

\subsection{Bulk Earth $\delta^{15} N$ and $N$ delivery during accretion}

A long-standing conundrum concerns the geochemistry and isotopic signature of $\mathrm{N}$ delivered to the planet during accretion. The budget estimate based on CC and EC compositions assumes that significant N was present in the Earth during its early history to ensure its participation in core formation. The implication is that $\mathrm{N}$ was not delivered in any late veneer, but instead was delivered during the main phase of accretion. It must have been in a reduced form, either $\mathrm{NH}_{4}^{+}$or as nitride, and contained within either silicate lattices or Fe-metal, as $\mathrm{N}_{2}$ would be too volatile, and perhaps not present in significant quantity in the inner solar system. Existing isotopic data is inconclusive on identifying a single meteoritic analogue. The presence of very depleted $\delta^{15} \mathrm{~N}$ values from the mantle has been suggested to reflect preservation of primordial EC-like material, though these are analyses from diamonds (Palot et al. 2012), and the behaviour and fractionation of $\mathrm{N}$ during diamond growth may not be fully understood. Additionally, CC have $\delta^{15} \mathrm{~N}$ that is generally enriched. Our BSE+atmosphere bulk $\delta^{15} \mathrm{~N}$, given masses in Table 13 and $\delta^{15} \mathrm{~N}$ values for MORB-source mantle $(-5 \%)$, high- $\mathrm{N}$ mantle $(+5 \%)$, continental crust $(7.3 \%)$, and atmosphere $(0 \%)$, is $2.1 \%$.

This estimate is distinct from either CC $(\sim 30 \%)$ or $\mathrm{EC}(\sim-25 \%)$, meaning either the Earth did not acquire its $\mathrm{N}$ from a single chondritic source or the process of core formation significantly fractionated $\mathrm{N}$. The Bulk Earth $\delta^{15} \mathrm{~N}$ value could be explained by a $\sim 50 \%$ contribution of CC-like and a $\sim 50 \%$ contribution of EC-like material during accretion, given no fractionation during core formation. If there was significant fractionation during core formation, it would have a large effect on residual $\mathrm{N}$ in the BSE. There is suggestion proposed that the dissolution of $\mathrm{N}$ into Fe-metal would preferentially fractionate light isotopes into the metal, following a Sievert's law-type reaction of $\mathrm{N}_{2} \rightleftharpoons 2 \mathrm{~N}$ dissolved (Dauphas and Marty, 1999). This assumption suggests that breaking of the ${ }^{14} \mathrm{~N}-{ }^{14} \mathrm{~N}$ bond is easier, so this isotope goes into the metal, leaving residual silicates enriched in $\delta^{15} \mathrm{~N}$. Were this the case, it would imply a higher contribution of EC to Earth's N. In 
principle, the same effect would be seen in $\mathrm{NH}_{4}^{+}$, but to our knowledge, there are no experimental studies measuring $\mathrm{N}$ isotopes in coexisting metal and silicates.

A possible source of information concerning fractionation during core formation could be measurements of pallasites, which are meteorites thought to represent core-mantle boundaries of planetesimals. Measurements made by Prombo and Clayton (1993) on coexisting silicate and metal in pallasites show that the silicate phase is almost always isotopically enriched compared to the metal phase. The fractionation is up to $\sim 70 \%$, which suggests fractionation during core formation could be quite large. Experimental work at pressures appropriate to Earth's core formation could help corroborate or quantify this effect for the Earth.

\section{Conclusions}

We have compiled a nominal, self-consistent, whole-Earth $\mathrm{N}$ budget based on two independent approaches. Both a chondritic comparison and literature compilation of terrestrial analyses reveal the BSE contains many present atmospheric masses of $\mathrm{N}$ (PAN). Estimates are $17 \pm 13 \times 10^{18} \mathrm{~kg}$ to $31 \pm 24 \times 10^{18} \mathrm{~kg} \mathrm{~N}$ and $27 \pm 16 \times 10^{18}$ $\mathrm{kg} \mathrm{N}$, respectively. Both estimates are higher than previous work, and suggests we have found the supposed "missing N". Additionally, several conclusions are apparent from each approach.

The chondritic comparison is consistent with the Earth receiving its $\mathrm{N}$ during the main phase of accretion. This indicates significant $\left(\sim 10^{20} \mathrm{~kg}\right) \mathrm{N}$ in the core, as $\mathrm{N}$ is siderophile under reducing conditions. If there is limited $\mathrm{N}$-isotope fractionation during core formation, $\delta^{15} \mathrm{~N}$ values for the BSE plus atmosphere suggest a mix of $\sim 50 \%$ enstatite-like and $\sim 50 \%$ carbonaceous-like chondritic material can explain the $\mathrm{N}$ content of Earth.

Our terrestrial literature compilation budget indicates that the continental crust $(\sim 0.5$ PAN $)$ and especially the mantle $(\sim 6 \mathrm{PAN})$ contain significant $\mathrm{N}$. Interestingly, $\mathrm{N}-\mathrm{Ar}$ and $\delta^{15} \mathrm{~N}$ data from MORB, OIB, and xenoliths identifies the existence of two distinct $\mathrm{N}$ reservoirs: MORB-source like (MSL) and high-N. MSL, which is $\sim 98 \%$ of the mantle by mass, contains $\sim 2$ atmospheric masses of $\mathrm{N}$, has depleted $\delta^{15} \mathrm{~N}$, and its Ar-isotopes suggest material was subducted deep in the geologic past. In contrast, high-N mantle has at least several atmospheric masses of $\mathrm{N}$, enriched $\delta^{15} \mathrm{~N}$, and appears to have been subducted more recently.

The presence of a large mass of subducted $\mathrm{N}$ in the mantle has important implications for the history of atmosphere-mantle communication over time. At present subduction rates, the entire atmospheric mass of $\mathrm{N}$ could be mixed into the mantle if only $\sim 50 \%$ of down-going $\mathrm{N}$ is returned to the atmosphere via arc volcanism. Nitrogen-Ar systematics indicate that the atmosphere and MSL are well mixed, and therefore that the mantle may serve to buffer the amount of $\mathrm{N}$ in the atmosphere. More reduced geochemical conditions at the surface and hotter mantle temperatures in the Archean may have lead to more efficient $\mathrm{N}$ subduction in the past, perhaps indicating a more massive atmosphere early in Earth history that has been progressively sequestered into the mantle.

This is an exciting time for research concerning the geologic $\mathrm{N}$ cycle. While the overall cycle is understood, there are areas for future research that are critical for more fully understanding $\mathrm{N}$ in the solid Earth. 
More analyses of $\mathrm{N}$ and $\mathrm{Ar}$ in $\mathrm{OIB}$ and xenoliths would help clarify the nature and extent of the high-N mantle. Experimental work investigating the behaviour of $\mathrm{N}$, specifically as $\mathrm{NH}_{4}^{+}$, during subduction and under mantle conditions should help reveal geochemical and isotopic fractionations during mantle transport. Modelling work, anchored to the budget presented herein, can elucidate the interchange of $\mathrm{N}$ and other surface materials through the solid Earth over geologic time.

\section{Acknowledgements}

The authors would like to acknowledge Dante Canil, Rameses D'Sousza, and Brendan Byrne for constructive feedback and discussion concerning this manuscript. We also thank Ralf Halama and Yuan Li for careful review of the manuscript. Funding was provided by NSERC Discovery grant to CG.

\section{References}

\section{References}

Adler, J.F., Williams, Q., 2005. A high-pressure X-ray diffraction study of iron nitrides: Implications for Earth's core. Journal of Geophysical Research 110, 1-11. doi/http://dx.doi.org/10.1029/ 2004JB003103.

Ahadnejad, V., Hirt, A.M., Valizadeh, M.V., Bokani, S.J., 2011. The ammonium content in the Malayer igneous and metamorphic rocks (Sanandaj-Sirjan Zone, Western Iran). Geologica Carpathica 62, 171-180. doi http://dx.doi.org/10.2478/v10096-011-0014-y

Arevalo, R., McDonough, W.F., Luong, M., 2009. The K/U ratio of the silicate Earth: Insights into mantle composition, structure and thermal evolution. Earth and Planetary Science Letters 278, 361-369. doi:http://dx.doi.org/10.1016/j.epsl.2008.12.023

Arevalo, R., McDonough, W.F., Stracke, A., Willbold, M., Ireland, T.J., Walker, R.J., 2013. Simplified mantle architecture and distribution of radiogenic power. Geochemistry, Geophysics, Geosystems 14, 2265-2285. doi:http://dx.doi.org/10.1002/ggge.20152.

Barry, P., Hilton, D., Halldórsson, S., Hahm, D., Marti, K., 2012. High precision nitrogen isotope measurements in oceanic basalts using a static triple collection noble gas mass spectrometer. Geochemistry Geophysics Geosystems 13, 1-16. doi:http://dx.doi.org/10.1029/2011GC003878.

Baur, W., Wlotzka, F., 1969. Handbook of Geochemistry. Springer-Verlag.

Bebout, G., Cooper, D., Bradley, A.D., Sadofsky, S.J., 1999a. Nitrogen-isotope record of fluid-rock interactions in the Skiddaw Auerole and granite, English Lake District. American Mineralogist 84, 1495-1505. 
Bebout, G., Fogel, M., 1992. Nitrogen-isotope compositions of metasedimentary rocks in the Catalina Schist, California: implications for metamorphic devolatilization history. Geochimica et Cosmochimica Acta 56, 2839-2849. doi:http://dx.doi.org/10.1016/0016-7037(92)90363-N.

Bebout, G., Ryan, J., Leeman, W., Bebout, A., 1999b. Fractionation of trace elements by subduction-zone metamorphism - effect of convergent-margin thermal evolution. Earth and Planetary Science Letters 171, 63-81. doi:http://dx.doi.org/10.1016/S0012-821X(99)00135-1.

Bebout, G.E., 1997. Nitrogen isotope tracers of high-temperature fluid-rock interactions: Case study of the Catalina Schist, California. Earth and planetary science letters 151, 77-90. doi http://dx.doi.org/10. 1016/S0012-821X(97)00117-9.

Berner, R.A., 1998. The carbon cycle and $\mathrm{CO}_{2}$ over Phanerozoic time: the role of land plants. Philosophical Transactions of the Royal Society of London. Series A, Mathematical and Physical Sciences 353, 75-82. doi http://dx.doi.org/10.1098/rstb.1998.0192.

Bogard, D., Clark, R., Keith, J., Reynolds, M., 1971. Noble gases and radionuclides in Lost City and other recently fallen meteorites. Journal of Geophysical Research 76, 4076-4083. doi http://dx.doi.org/10. 1029/JB076i017p04076.

Boyd, S., 2001. Nitrogen in future biosphere studies. Chemical Geology 176, 1-30. doi:http://dx.doi. org/10.1016/S0009-2541(00)00405-8

Boyd, S., Hall, A., Pillinger, C., 1993. The measurement of $\delta^{15} \mathrm{~N}$ in crustal rocks by static vacuum mass spectrometry: Application to the origin of the ammonium in the Cornubian batholith, southwest England. Geochimica et Cosmochimica Acta 57, 1339-1347. doi:http://dx.doi.org/10.1016/0016-7037(93) 90070-D.

Boyd, S., Philippot, P., 1998. Precambrian ammonium biogeochemistry: a study of the Moine metasediments, Scotland. Chemical Geology 144, 257-268. doi http://dx.doi.org/10.1016/S0009-2541(97)00135-6.

Bräuer, K., Hahne, J., 2005. Methodical aspects of the ${ }^{15} \mathrm{~N}$-analysis of Precambrian and Paleozoic sediments rich in organic matter. Chemical Geology 218, 361-368. doi/http://dx.doi.org/doi:10.1016/j . chemgeo.2005.01.004

Brown, J., Colling, A., Park, D., Phillips, J., Rothery, D., Wright, J., 1989. Ocean chemistry and deep-sea sediments. volume 5 of Open University. Butterworth-Heinemann.

Busigny, V., Ader, M., Cartigny, P., 2005a. Quantification and isotopic analysis of nitrogen in rocks at the ppm level using sealed tube combustion technique: A prelude to the study of altered oceanic crust. Chemical geology 223, 249-258. doi:http://dx.doi.org/10.1016/j.chemgeo.2005.08.002 
Busigny, V., Cartigny, P., Philippot, P., 2011. Nitrogen isotopes in ophiolitic metagabbros: A re-evaluation of modern nitrogen fluxes in subduction zones and implication for the early earth atmosphere. Geochimica et Cosmochimica Acta 75, 7502-7521. doi http://dx.doi.org/10.1016/j.gca.2011.09.049

Busigny, V., Cartigny, P., Philippot, P., Ader, M., Javoy, M., 2003. Massive recycling of nitrogen and other fluid-mobile elements ( $\mathrm{K}, \mathrm{Rb}, \mathrm{Cs}, \mathrm{H})$ in a cold slab environment: evidence from HP to UHP oceanic metasediments of the Schistes Lustrés nappe (western Alps, Europe). Earth and Planetary Science Letters 215, 27-42. doi:http://dx.doi.org/10.1016/S0012-821X(03)00453-9.

Busigny, V., Laverne, C., Bonifacie, M., 2005b. Nitrogen content and isotopic composition of oceanic crust at a superfast spreading ridge: A profile in altered basalts from ODP Site 1256, Leg 206. Geochemistry, Geophysics, Geosystems 6, 1-16. doi:http://dx.doi.org/10.1029/2005GC001020.

Busigny, V., Lebeau, O., Ader, M., Krapež, B., Bekker, A., 2013. Nitrogen cycle in the late archean ferruginous ocean. Chemical Geology 362, 115-130. doi http://dx.doi.org/10.1016/j.chemgeo.2013. 06.023 .

Byrne, B., Goldblatt, C., 2014. Radiative forcings for 28 potential Archean greenhouse gases. Climate of the Past 10, 1779-1801. doi:http://dx.doi.org/10.5194/cp-10-1779-2014.

Cartigny, P., 2005. Stable isotopes and the origin of diamond. Elements 1, 79-84. doi:http://dx.doi.org/ 10.2113/gselements.1.2.79

Cartigny, P., Harris, J., Javoy, M., 2001. Diamond genesis, mantle fractionations and mantle nitrogen content: a study of $\delta^{13} \mathrm{C}-\mathrm{N}$ concentrations in diamonds. Earth and Planetary Science Letters 185, 85-98. doi http://dx.doi.org/10.1016/S0012-821X(00)00357-5

Chassefière, E., Wieler, R., Marty, B., Leblanc, F., 2012. The evolution of Venus: Present state of knowledge and future exploration. Planetary and Space Science 63, 15-23. doi http://dx.doi.org/10.1016/j.pss . 2011.04.007.

Chicarelli, M.I., Hayes, J., Popp, B.N., Eckardt, C.B., Maxwell, J.R., 1993. Carbon and nitrogen isotopic compositions of alkyl porphyrins from the triassic serpiano oil shale. Geochimica et cosmochimica acta 57, 1307-1311. doi http://dx.doi.org/10.1016/0016-7037(93)90067-7.

Cooper, D., Bradley, A., 1990. The ammonium content of granites in the English Lake District. Geological Magazine 127, 579-586. doi/http://dx.doi.org/10.1017/S0016756800015466.

Crabb, J., Anders, E., 1981. Noble gases in E-chondrites. Geochimica et Cosmochimica Acta 45, 2443-2464. doi:http://dx.doi.org/10.1016/0016-7037(81)90097-1. 
Cremonese, L., Shields-Zhou, G., Struck, U., Ling, H.F., Och, L., Chen, X., Li, D., 2013. Marine biogeochemical cycling during the early Cambrian constrained by a nitrogen and organic carbon isotope study of the Xiaotan section, South China. Precambrian Research 225, 148-165. doi http: //dx.doi.org/10.1016/j.precamres.2011.12.004.

Cruz, M.D.R., 2011. $\mathrm{NH}_{4}$-bearing micas in poly-metamorphic Alpujárride micaschists and gneisses from the central zone of the Betic Cordillera (Spain): tectono-metamorphic and crystal-chemical constraints. Mineralogy and Petrology 101, 225-244. doi http://dx.doi.org/10.1007/s00710-011-0146-x.

Dauphas, N., Marty, B., 1999. Heavy nitrogen in carbonatites of the Kola Peninsula: A possible signature of the deep mantle. Science 286, 2488-2490. doi:http://dx.doi.org/10.1126/science.286.5449.2488

Davies, T., Gorsline, D., 1976. Oceanic sediments and sedimentary processes. Chemical Oceanography 5, 80.

Delwiche, C.C., 1970. The nitrogen cycle. Scientific American 223, 136-146. doi http://dx.doi.org/10. 1038/scientificamerican0970-136.

Dixon, J.C., Campbell, S.W., Durham, B., 2012. Geologic nitrogen and climate change in the geochemical budget of Kärkevagge, Swedish Lapland. Geomorphology 167-168, 70-76. doi http://dx.doi.org/10. 1016/j.geomorph.2012.03.011.

Duit, W., Jansen, J.B.H., van Breemen, A., Bos, A., 1986. Ammonium micas in metamorphic rocks as exemplified by Dome de l'Agout (France). American Journal of Science 286, 702-732. doi http://dx. doi.org/10.2475/ajs.286.9.702.

Elkins, L., Fischer, T., Hilton, D., Sharp, Z., McKnight, S., Walker, J., 2006. Tracing nitrogen in volcanic and geothermal volatiles from the Nicaraguan volcanic front. Geochimica et Cosmochimica Acta 70, 5215-5235. doi.http://dx.doi.org/10.1016/j.gca.2006.07.024.

Exley, R., Boyd, S., Mattey, D., Pillinger, C., 1987. Nitrogen isotope geochemistry of basaltic glasses: implications for mantle degassing and structure? Earth and planetary science letters 81, 163-174. doi http://dx.doi.org/10.1016/0012-821X(87)90153-1.

Foley, S.F., Jenner, G.A., 2004. Trace element partitioning in lamproitic magmas-the Gaussberg olivine leucitite. Lithos 75, 19-38. doi http://dx.doi.org/10.1016/j.lithos.2003.12.020.

Frost, B.R., 1991. Introduction to oxygen fugacity and its petrologic importance. Reviews in Mineralogy and Geochemistry 25, 1-9.

Frost, D., McCammon, C., 2008. The redox state of Earth's mantle. Annual Review of Earth and Planetary Sciences 36, 389-420. 
Frost, D.J., Liebske, C., Langenhorst, F., McCammon, C.A., Trønnes, R.G., Rubie, D.C., 2004. Experimental evidence for the existence of iron-rich metal in the earth's lower mantle. Nature 428, 409-412.

Fuchsman, C.A., Murray, J.W., Konovalov, S.K., 2008. Concentration and natural stable isotope profiles of nitrogen species in the Black Sea. Marine Chemistry 111, 90-105.

Fujimaki, H., Tatsumoto, M., Aoki, K.i., 1984. Partition coefficients of Hf, Zr, and REE between phenocrysts and groundmasses. Journal of Geophysical Research: Solid Earth (1978-2012) 89, B662-B672.

Galli, A., Le Bayon, B., Schmidt, M., Burg, J.P., Caddick, M., Reusser, E., 2011. Granulites and chrnockites of the Gruf Complex: Evidence for Permian ultra-high temperature metamorphism in the Central Alps. Lithos 124, 17-45.

Garcia, H.E., Locarnini, R.A., Boyer, T.P., Antonov, J.I., 2010. World ocean atlas 2009, volume 4: Nutrients (phosphate, nitrate, silicate).

Garvin, J., Buick, R., Anbar, A., Arnold, G., Kaufman, A., 2009. Isotopic evidence for an aerobic nitrogen cycle in the latest Archean. Science 323, 1045-1048.

Godfrey, L., Poulton, S., Bebout, G., Fralick, P., 2013. Stability of the nitrogen cycle during development of sulfidic water in the redox-stratified late Paleoproterozoic Ocean. Geology 41, 655-658.

Goldblatt, C., Claire, M., Lenton, T., Matthews, A., Watson, A., Zahnle, K., 2009. Nitrogen-enhanced greenhouse warming on early Earth. Nature Geoscience 2, 891-896.

Goldblatt, C., Zahnle, K., Sleep, N., Nisbet, E., 2010. The Eons of Chaos and Hades. Solid Earth 1, 1-3.

Grady, M.M., Wright, I., Carr, L., Pillinger, C., 1986. Compositional differences in enstatite chondrites based on carbon and nitrogen stable isotope measurements. Geochimica et Cosmochimica Acta 50, $2799-2813$. doi:http://dx.doi.org/10.1016/0016-7037(86)90228-0.

Grady, M.M., Wright, I.P., 2003. Elemental and isotopic abundances of carbon and nitrogen in meteorites. Space Science Reviews 106, 231-248.

Greenfield, L., 1988. 3.2 Forms of Nitrogen in Beacon Sandstone Rocks Containing Endolithic Microbial Communities in Southern Victoria Land, Antarctica. Polarforschung 58, 211-218.

Greenfield, L., 1991. Fixed ammonium in antarctic rocks and soils and a possible cause of underestimation. Soil Biology and Biochemistry 23, 397-399.

Gruber, N., Sarmiento, J.L., 1997. Global patterns of marine nitrogen fixation and denitrification. Global Biogeochemical Cycles 11, 235-266.

Gu, Y.J., Dziewonski, A.M., 2001. Variations in thickness of the upper mantle transition zone, in: Long-term observations in the oceans: Proceedings of the OHP/ION Joint Symposium, Japan, January, pp. 21-27. 
Haendel, D., Mühle, K., Nitzsche, H.M., Stiehl, G., Wand, U., 1986. Isotopic variations of the fixed nitrogen in metamorphic rocks. Geochimica et cosmochimica Acta 50, 749-758.

Halama, R., Bebout, G., John, T., Scambelluri, M., 2012. Nitrogen recycling in subducted mantle rocks and implications for the global nitrogen cycle. International Journal of Earth Sciences , 1-19.

Halama, R., Bebout, G.E., John, T., Schenk, V., 2010. Nitrogen recycling in subducted oceanic lithosphere: The record in high-and ultrahigh-pressure metabasaltic rocks. Geochimica et Cosmochimica Acta 74, $1636-1652$.

Hall, A., 1987. The ammonium content of Caledonian granites. Journal of the Geological Society 144, $671-674$.

Hall, A., 1999. Ammonium in granites and its petrogenetic significance. Earth-Science Reviews 45, 145-165.

Hall, A., Bencini, A., Poli, G., 1991. Magmatic and hydrothermal ammonium in granites of the Tuscan magmatic province, Italy. Geochimica et Cosmochimica Acta 55, 3657-3664.

Hall, A., Pereira, M., Bea, F., 1996. The abundance of ammonium in the granites of central spain, and the behaviour of the ammonium ion during anatexis and fractional crystallization. Mineralogy and Petrology $56,105-123$.

Halliday, A., 2004. The Origin and Earliest History of Earth. Treatise on Geochemistry 1, 509-558.

Halliday, A.N., 2013. The origins of volatiles in the terrestrial planets. Geochimica et Cosmochimica Acta $105,146-171$.

Hansen, E., Stuk, M., 1993. Orthopyroxene-bearing, mafic migmatites at Cone Peak, California: evidence for the formation of migmatitic granulites by anatexis in an open system. Journal of Metamorphic Geology 11, 291-307.

Harries, D., Hoppe, P., Lagenhorst, F., 2015. Reactive ammonia in the solar protoplanetary disk and the origin of Earth's nitrogen. Nature Geoscience 8, 97-101. doi http://dx.doi.org/10.1038/ngeo2339.

Hartmann, W.K., Davis, D.R., 1975. Satellite-sized planetesimals and lunar origin. Icarus 24, 504-515.

Haynes, W., Bruno, T.J., Lide, D.R. (Eds.), 2014. CRC Handbook of Chemistry and Physics. volume 95. CRC Press, Boca Raton, FL USA.

Herzberg, C., Condie, K., Korenaga, J., 2010. Thermal history of the earth and its petrological expression. Earth and Planetary Science Letters 292, 79-88.

Holland, H.D., 1984. The chemical evolution of the atmosphere and oceans. Princeton University Press. 
Holloway, J., Dahlgren, R., 2002. Nitrogen in rock: Occurrences and biogeochemical implications. Global Biogeochemical Cycles 16, 65-1-65-17.

Holloway, J.M., Dahlgren, R.A., Casey, W.H., 2001. Nitrogen release from rock and soil under simulated field conditions. Chemical Geology 174, 403-414.

Honma, H., 1996. High ammonium contents in the 3800 Ma isua supracrustal rocks, central west greenland. Geochimica et cosmochimica acta 60, 2173-2178.

Honma, H., Itihara, Y., 1981. Distribution of ammonium in minerals of metamorphic and granitic rocks. Geochimica et Cosmochimica Acta 45, 983-988.

Hopp, J., Trieloff, M., Ott, U., Korochantseva, E.V., Buykin, A.I., 2014. ${ }^{39}$ Ar- ${ }^{40}$ Ar chronology of the enstatite chondrite parent bodies. Meteoritics \& Planetary Science 49, 358-372.

Itihara, Y., Honma, H., 1979. Ammonium in biotite from metamorphic and granitic rocks of Japan. Geochimica et Cosmochimica Acta 43, 503-509.

Itihara, Y., Suwa, K., Hoshino, M., 1986. Organic matter in the Kavirondian sedimentary rocks of Archaean period in Kenya. Geochemical Journal 20, 201-207.

Itihara, Y., Tainosho, Y., 1989. Ammonium and insoluble nitrogen in precambrian rock from the Gawler Craton, Australia: Inference of life activity. Journal of the Geological Society of Japan 95, 439-445.

Jia, Y., 2006. Nitrogen isotope fractionations during progressive metamorphism: A case study from the Paleozoic Cooma metasedimentary complex, southeastern Australia. Geochimica et cosmochimica acta $70,5201-5214$.

Jia, Y., Kerrich, R., 1999. Nitrogen isotope systematics of mesothermal lode gold deposits: Metamorphic, granitic, meteoric water, or mantle origin? Geology 27, 1051-1054.

Jia, Y., Kerrich, R., 2000. Giant quartz vein systems in accretionary orogenic belts: the evidence for a metamorphic fluid origin from $\delta^{15} \mathrm{~N} \delta^{13} \mathrm{C}$ studies. Earth and Planetary Science Letters 184, 211-224.

Jia, Y., Kerrich, R., Gupta, A., Fyfe, W., 2003. ${ }^{15}$ N-enriched Gondwana lamproites, eastern India: crustal $\mathrm{N}$ in the mantle source. Earth and Planetary Science Letters 215, 43-56.

Kadik, A., Kurovskaya, N., Ignat'ev, Y., Kononkova, N., Koltashev, V., Plotnichenko, V., 2011. Influence of oxygen fugacity on the solubility of nitrogen, carbon, and hydrogen in $\mathrm{FeO}-\mathrm{Na}_{2} \mathrm{O}-\mathrm{SiO}_{2}-\mathrm{Al}_{2} \mathrm{O}_{3}$ melts in equilibrium with metallic iron at $1.5 \mathrm{GPa}$ and $1400^{\circ} \mathrm{C}$. Geochemistry International 49, 429-438.

Kaid, N.A., Cowan, N.B., 2015. The feeding zones of terrestrial planets and insights into Moon formation. Icarus 252, 161-174. doi http://dx.doi.org/10.1016/j.icarus.2015.01.013. 
Kavanagh, L., Goldblatt, C., 2015. Using raindrops to constrain past atmospheric density. Earth and Planetary Science Letters - In review 413, 51-58.

Kelly, J.F., 2000. Stable isotopes of carbon and nitrogen in the study of avian and mammalian trophic ecology. Canadian Journal of Zoology 78, 1-27.

Kerrich, R., Jia, Y., Manikyamba, C., Naqvi, S., 2006. Secular variations of N-isotopes in terrestrial reservoirs and ore deposits. Evolution of Early Earth's Atmosphere, Hydrosphere, And Biosphere: Constraints from Ore Deposits 198, 81-104.

Khan, A.A., Baur, W.H., 1972. Salt hydrates. vii. the crystal structures of sodium ammonium orthochromate dihydrate and magnesium diammonium bis (hydrogen orthophosphate) tetrahydrate and a discussion of the ammonium ion. Acta Crystallographica Section B: Structural Crystallography and Crystal Chemistry $28,683-693$.

Korenaga, J., 2011. Thermal evolution with a hydrating mantle and the initiation of plate tectonics in the early Earth. Journal of Geophysical Research 116, 1-20.

Krooss, B.M., Friberg, L., Gensterblum, Y., Hollenstein, J., Prinz, D., Littke, R., 2005. Investigation of the pyrolytic liberation of molecular nitrogen from palaeozoic sedimentary rocks. International Journal of Earth Sciences 94, 1023-1038.

Lécuyer, C., Simon, L., Guyot, F., 2000. Comparison of carbon, nitrogen and water budgets on Venus and the Earth. Earth and Planetary Science Letters 181, 33-40.

Lee, C.T.A., Luffi, P., Chin, E.J., 2011. Building and destroying continental mantle. Annual Review of Earth and Planetary Sciences 39, 59-90.

Li, L., Bebout, G., Idleman, B., 2007. Nitrogen concentration and $\delta^{15} \mathrm{~N}$ of altered oceanic crust obtained on ODP Legs 129 and 185: Insights into alteration-related nitrogen enrichment and the nitrogen subduction budget. Geochimica et Cosmochimica Acta 71, 2344-2360.

Li, L., Bebout, G.E., 2005. Carbon and nitrogen geochemistry of sediments in the Central American convergent margin: Insights regarding subduction input fluxes, diagenesis, and paleoproductivity. Journal of Geophysical Research: Solid Earth (1978-2012) 110.

Li, L., Zheng, Y.F., Cartigny, P., Li, J., 2014. Anomalous nitrogen isotopes in ultrahigh-pressure metamorphic rocks from the Sulu orogenic belt: Effect of abiotic nitrogen reduction during fluid-rock interaction. Earth and Planetary Science Letters 403, 67-78.

Li, Y., Huang, R., Wiedenbeck, M., Keppler, H., 2015. Nitrogen distribution between aqueous fluids and silicate melts. Earth and Planetary Science Letters 411, 218-228. 
Li, Y., Keppler, H., 2014. Nitrogen speciation in mantle and crustal fluids. Geochimica et Cosmochimica Acta 129, 13-32.

Li, Y., Wiedenbeck, M., Shcheka, S., Keppler, H., 2013. Nitrogen solubility in upper mantle minerals. Earth and Planetary Science Letters 377, 311-323.

Libourel, G., Marty, B., Humbert, F., 2003. Nitrogen solubility in basaltic melt. Part I. Effect of oxygen fugacity. Geochimica et Cosmochimica Acta 67, 4123-4135.

Limpert, E., Stahel, W.A., Abbt, M., 2001. Log-normal distributions across the sciences: Keys and clues on the charms of statistics, and how mechanical models resembling gambling machines offer a link to a handy way to characterize log-normal distributions, which can provide deeper insight into variability and probability - normal or log-normal: That is the question. BioScience 51, 341-352.

Marty, B., 1995. Nitrogen content of the mantle inferred from $\mathrm{N}_{2}-\mathrm{Ar}$ correlation in oceanic basalts. Nature $377,326-329$.

Marty, B., 2012. The origins and concentrations of water, carbon, nitrogen and noble gases on Earth. Earth and Planetary Science Letters 313, 56-66.

Marty, B., Dauphas, N., 2003. The nitrogen record of crust-mantle interaction and mantle convection from Archean to present. Earth and Planetary Science Letters 206, 397-410.

Marty, B., Hashizume, K., Chaussidon, M., Wieler, R., 2003. Nitrogen isotopes on the Moon: Archives of the solar and planetary contributions to the inner solar system. Space science reviews 106, 175-196.

Marty, B., Humbert, F., 1997. Nitrogen and argon isotopes in oceanic basalts. Earth and Planetary Science Letters 152, 101-112.

Marty, B., Zimmermann, L., 1999. Volatiles (He, C, N, Ar) in mid-ocean ridge basalts: Assesment of shallow-level fractionation and characterization of source composition. Geochimica et Cosmochimica Acta 63, 3619-3633.

Marty, B., Zimmermann, L., Pujol, M., Burgess, R., Philippot, P., 2013. Nitrogen isotopic composition and density of the Archean atmosphere. Science 342, 101-104.

Mathew, K., Marti, K., 2001. Lunar nitrogen: indigenous signature and cosmic-ray production rate. Earth and Planetary Science Letters 184, 659-669.

Mayne, K., 1957. Natural variations in the nitrogen isotope abundance ratio in igneous rocks. Geochimica et Cosmochimica Acta 12, 185-189.

Mazor, E., Heymann, D., Anders, E., 1970. Noble gases in carbonaceous chondrites. Geochimica et Cosmochimica Acta 34, 781-824. 
Mikhail, S., Sverjensky, D.A., 2014. Nitrogen speciation in upper mantle fluids and the origin of Earth's nitrogen-rich atmosphere. Nature Geoscience 7, 816-819.

Mingram, B., Bräuer, K., 2001. Ammonium concentration and nitrogen isotope composition in metasedimentary rocks from different tectonometamorphic units of the European Variscan belt. Geochimica et Cosmochimica Acta 65, 273-287.

Mitchell, E.C., Fischer, T.P., Hilton, D.R., Hauri, E.H., Shaw, A.M., de Moor, J.M., Sharp, Z.D., Kazahaya, K., 2010. Nitrogen sources and recycling at subduction zones: Insights from the Izu-Bonin-Mariana arc. Geochemistry, Geophysics, Geosystems 11.

Mitchell, R.H., 1995. Melting experiments on a sanidine phlogopite lamproite at 4-7 GPa and their bearing on the sources of lamproitic magmas. Journal of Petrology 36, 1455-1474.

Mohapatra, R., Harrison, D., Ott, U., Gilmour, J., Trieloff, M., 2009. Noble gas and nitrogen isotopic components in Oceanic Island Basalts. Chemical Geology 266, 29-37.

Morford, S.L., Houlton, B.Z., Dahlgren, R.A., 2011. Increased forest ecosystem carbon and nitrogen storage from nitrogen rich bedrock. Nature 477, 78-81.

Murphy, D., Collerson, K., Kamber, B., 2002. Lamproites from Gaussberg, Antarctica: possible transition zone melts of Archaean subducted sediments. Journal of Petrology 43, 981-1001.

Mysen, B.O., Fogel, M.L., 2010. Nitrogen and hydrogen isotope compositions and solubility in silicate melts in equilibrium with reduced $(\mathrm{N}+\mathrm{H})$-bearing fluids at high pressure and temperature: Effects of melt structure. American Mineralogist 95, 987-999.

Mysen, B.O., Tomita, T., Ohtani, E., Suzuki, A., 2014. Speciation of and D/H partitioning between fluids and melts in silicate-D-O-H-C-N systems determined in-situ at upper mantle temperatures, pressures, and redox conditions. American Mineralogist 99, 578-588.

Mysen, B.O., Yamashita, S., Chertkova, N., 2008. Solubility and solution mechanisms of NOH volatiles in silicate melts at high pressure and temperature-amine groups and hydrogen fugacity. Am. Mineral 93, $1760-1770$.

Nakagawa, T., Tackley, P.J., 2012. Influence of magmatism on mantle cooling, surface heat flow and Urey ratio. Earth and Planetary Science Letters 329, 1-10.

Nishio, Y., Ishii, T., Gamo, T., Sano, Y., 1999. Volatile element isotopic systematics of the Rodrigues Triple Junction Indian Ocean MORB: implications for mantle heterogeneity. Earth and Planetary Science Letters $170,241-253$. 
Nishizawa, M., Sano, Y., Ueno, Y., Maruyama, S., 2007. Speciation and isotope ratios of nitrogen in fluid inclusions from seafloor hydrothermal deposits at 3.5 Ga. Earth and Planetary Science Letters 254, $332-344$.

Oró, J., 1961. Comets and the formation of biochemical compounds on the primitive Earth. Nature 190, 389-390. doi http://dx.doi.org/10.1038/190389a0

Palme, H., O’Neill, H., 2014. Cosmochemical Estimates of Mantle Composition. Planets, Asteriods, Comets and The Solar System, Volume 2 of Treatise on Geochemistry (Second Edition). Edited by Andrew M. Davis. Elsevier, 2014., p. 149-211 1, 1-35. doi/http://dx.doi.org/10.1016/B978-0-08-095975-7. 00201-1.

Palot, M., Cartigny, P., Harris, J., Kaminsky, F., Stachel, T., 2012. Evidence for deep mantle convection and primordial heterogeneity from nitrogen and carbon stable isotopes in diamond. Earth and Planetary Science Letters 357, 179-193.

Palya, A.P., Buick, I.S., Bebout, G.E., 2011. Storage and mobility of nitrogen in the continental crust: Evidence from partially melted metasedimentary rocks, Mt. Stafford, Australia. Chemical Geology 281, $211-226$.

Papineau, D., Purohit, R., Goldberg, T., Pi, D., Shields, G.A., Bhu, H., Steele, A., Fogel, M.L., 2009. High primary productivity and nitrogen cycling after the Paleoproterozoic phosphogenic event in the Aravalli Supergroup, India. Precambrian Research 171, 37-56.

Patzer, A., Schultz, L., 2002. Noble gases in enstatite chondrites ii: The trapped component. Meteoritics \& Planetary Science 37, 601-612.

Pearson, V., Sephton, M.A., Franchi, I., Gibson, J., Gilmour, I., 2006. Carbon and nitrogen in carbonaceous chondrites: Elemental abundances and stable isotopic compositions. Meteoritics and Planetary Science 41, 1899-1918.

Peters, K., Sweeney, R., Kaplan, I., 1978. Correlation of carbon and nitrogen stable isotope ratios in sedimentary organic matter. Limnololgy and Oceanography 23, 598-604.

Philippot, P., Busigny, V., Scambelluri, M., Cartigny, P., 2007. Oxygen and nitrogen isotopes as tracers of fluid activities in serpentinites and metasediments during subduction. Mineralogy and Petrology 91, $11-24$.

Pinti, D., Hashizume, K., Matsuda, J., 2001. Nitrogen and argon signatures in 3.8 to 2.8 Ga metasediments: Clues on the chemical state of the Archean ocean and the deep biosphere. Geochimica et Cosmochimica Acta $65,2301-2315$. 
Pitcairn, I., Teagle, D., Kerrich, R., Craw, D., Brewer, T., 2005. The behavior of nitrogen and nitrogen isotopes during metamorphism and mineralization: evidence from the Otago and Alpine Schists, New Zealand. Earth and Planetary Science Letters 233, 229-246.

Plessen, B., Harlov, D.E., Henry, D., Guidotti, C.V., 2010. Ammonium loss and nitrogen isotopic fractionation in biotite as a function of metamorphic grade in metapelites from western Maine, USA. Geochimica et Cosmochimica Acta 74, 4759-4771.

Pontes, F.V., Carneiro, M.C., Vaitsman, D.S., da Rocha, G.P., da Silva, L.I., Neto, A.A., Monteiro, M.I.C., 2009. A simplified version of the total kjeldahl nitrogen method using an ammonia extraction ultrasoundassisted purge-and-trap system and ion chromatography for analyses of geological samples. Analytica Chimica Acta 632, 284-288.

Prombo, C.A., Clayton, R.N., 1993. Nitrogen isotopic compositions of iron meteorites. Geochimica et cosmochimica acta 57, 3749-3761.

Pujol, M., Marty, B., Burgess, R., 2011. Chondritic-like xenon trapped in Archean rocks: A possible signature of the ancient atmosphere. Earth and Planetary Science Letters 308, 298-306.

Quan, T., van de Schootbrugge, B., Field, M., Rosenthal, Y., Falkowski, P., 2008. Nitrogen isotope and trace metal analyses from the Mingolsheim core (Germany): Evidence for redox variations across the Triassic-Jurassic boundary. Global Biogeochemical Cycles 22, GB2014.

Quan, T.M., Adigwe, E.N., Riedinger, N., Puckette, J., 2013a. Evaluating nitrogen isotopes as proxies for depositional environmental conditions in shales: Comparing Caney and Woodford Shales in the Arkoma Basin, Oklahoma. Chemical Geology 360, 231-240.

Quan, T.M., Wright, J.D., Falkowski, P.G., 2013b. Co-variation of nitrogen isotopes and redox states through glacial-interglacial cycles in the Black Sea. Geochimica et Cosmochimica Acta 112, 305-320.

Rau, G., Arthur, M., Dean, W., 1987. ${ }^{15} \mathrm{~N} /{ }^{14} \mathrm{~N}$ variations in Cretaceous Atlantic sedimentary sequences: implication for past changes in marine nitrogen biogeochemistry. Earth and Planetary Science Letters 82, 269-279.

Ringwood, A., Anderson, D.L., 1977. Earth and venus: A comparative study. Icarus 30, 243-253.

Rollinson, H.R., 1993. Using Geochecmical Data: Evaluation, Presentation, Interpretation. Pearson.

Roskosz, M., Bouhifd, M., Jephcoat, A., Marty, B., Mysen, B., 2013. Nitrogen solubility in molten metal and silicate at high pressure and temperature. Geochimica et Cosmochimica Acta 121, 15-28.

Roskosz, M., Mysen, B.O., Cody, G.D., 2006. Dual speciation of nitrogen in silicate melts at high pressure and temperature: an experimental study. Geochimica et Cosmochimica Acta 70, 2902-2918. 
Rudnick, R., Gao, S., 2003. Composition of the Continental Crust. Treatise on Geochemistry 3, 1-64.

Rudnick, R., Gao, S., 2014. Composition of the Continental Crust. Treatise on Geochemistry 4, 1-69.

Sadofsky, S.J., Bebout, G.E., 2000. Ammonium partitioning and nitrogen-isotope fractionation among coexisting micas during high-temperature fluid-rock interactions: Examples from the New England Appalachians. Geochimica et Cosmochimica Acta 64, 2835-2849.

Sadofsky, S.J., Bebout, G.E., 2003. Record of forearc devolatilization in low-T, high-P/T metasedimentary suites: Significance for models of convergent margin chemical cycling. Geochemistry, Geophysics, Geosystems 4.

Sadofsky, S.J., Bebout, G.E., 2004. Nitrogen geochemistry of subducting sediments: New results from the Izu-Bonin-Mariana margin and insights regarding global nitrogen subduction. Geochemistry, Geophysics, Geosystems 5 .

Sakai, H., Des Marais, D., Ueda, A., Moore, J., 1984. Concentrations and isotope ratios of carbon, nitrogen and sulfur in ocean-floor basalts. Geochimica et Cosmochimica Acta 48, 2433-2441.

Sandu, C., Lenardic, A., McGovern, P., 2011. The effects of deep water cycling on planetary thermal evolution. Journal of Geophysical Research 116, 1-15. doi/http://dx.doi.org/10.1029/2011JB008405.

Sano, Y., Takahata, N., Nishio, Y., Marty, B., 1998. Nitrogen recycling in subduction zones. Geophysical research letters 25, 2289-2292.

Sephton, M.A., Amor, K., Franchi, I.A., Wignall, P.B., Newton, R., Zonneveld, J.P., 2002. Carbon and nitrogen isotope disturbances and an end-Norian (Late Triassic) extinction event. Geology 30, 1119-1122.

Shearer, C., Papike, J., 1999. Magmatic evolution of the Moon. American Mineralogist 84, 1469-1494.

Smart, K.A., Chacko, T., Stachel, T., Muehlenbachs, K., Stern, R.A., Heaman, L.M., 2011. Diamond growth from oxidized carbon sources beneath the Northern Slave Craton, Canada: A $\delta^{13} \mathrm{C}-\mathrm{N}$ study of eclogite-hosted diamonds from the Jericho kimberlite. Geochimica et Cosmochimica Acta 75, 6027-6047.

Smith, E.M., Kopylova, M.G., Peck, W., 2014. Implications of metallic iron for diamonds and nitrogen in the sublithospheric mantle. Canadian Journal of Earth Sciences 51, 510-516.

Som, S.M., Catling, D.C., Harnmeijer, J.P., Polivka, P.M., Buick, R., 2012. Air density 2.7 billion years ago limited to less than twice modern levels by fossil raindrop imprints. Nature 484, 359-362.

Stachel, T., Harris, J.W., 2009. Formation of diamond in the Earth's mantle. Journal of Physics: Condensed Matter 21, 364206. 
Sullivan, P.J., Sposito, G., Strathouse, S., Hansen, C.L., 1979. Geologic nitrogen and the occurrence of high nitrate soils in the western San Joaquin Valley, California. University of California, Division of Agriculture and Natural Resources.

Tainton, K.M., McKenzie, D., 1994. The generation of kimberlites, lamproites, and their source rocks. Journal of Petrology 35, 787-817.

Taylor, S.R., 1992. Solar system evolution: a new perspective. An inquiry into the chemical composition, origin, and evolution of the solar system. Cambridge University Press.

Taylor, S.R., McLennan, S.M., 1995. The geochemical evolution of the continental crust. Reviews of Geophysics 33, 241-265.

Thamdrup, B., 2012. New pathways and processes in the global nitrogen cycle. Annual Review of Ecology, Evolution, and Systematics 43, 407-428.

Ussiri, D., Lal, R., 2013. Global nitrogen cycle. Soil Emission of Nitrous Oxide and its Mitigation , 29-62.

Veizer, J., Mackenzie, F., 2003. Evolution of sedimentary rocks. Treatise on geochemistry 7, 369-407.

Velinsky, D.J., Fogel, M.L., Todd, J.F., Tebo, B.M., 1991. Isotopic fractionation of dissolved ammonium at the oxygen-hydrogen sulfide interface in anoxic waters. Geophysical Research Letters 18, 649-652.

Visser, D., 1993. The metamorphic evolution of the Bamble sector, south Norway: A paragenetic and mineral chemical study of cordierite-orthoamphibole-bearing rocks with special reference to borosilicate-bearing mineral assemblages. Geologica Ultraiectina 103, 1-159.

Wasson, J., Kallemeyn, G., 1988. Compositions of chondrites. Philosophical Transactions of the Royal Society of London. Series A, Mathematical and Physical Sciences 325, 535-544. doi:http://www.jstor. org/stable/37983.

Watanabe, Y., Naraoka, H., Wronkiewicz, D., Condie, K., Ohmoto, H., 1997. Carbon, nitrogen, and sulfur geochemistry of Archean and Proterozoic shales from the Kaapvaal Craton, South Africa. Geochimica et Cosmochimica Acta 61, 3441-3459.

Watenphul, A., Wunder, B., Heinrich, W., 2009. High-pressure ammonium-bearing silicates: Implications for nitrogen and hydrogen storage in the Earth's mantle. American Mineralogist 94, 283-292.

Watenphul, A., Wunder, B., Wirth, R., Heinrich, W., 2010. Ammonium-bearing clinopyroxene: A potential nitrogen reservoir in the Earth's mantle. Chemical Geology 270, 240-248.

Wedepohl, H.K., 1995. The composition of the continental crust. Geochimica et Cosmochimica Acta 59, $1217-1232$. 
White, W.M., 2010. Oceanic island basalts and mantle plumes: the geochemical perspective. Annual Review of Earth and Planetary Sciences 38, 133-160.

Whittaker, E., Muntus, R., 1970. Ionic radii for use in geochemistry. Geochimica et Cosmochimica Acta 34, 945-956.

Wiechert, U., Halliday, A., Lee, D.C., Snyder, G., Taylor, L., Rumble, D., 2001. Oxygen isotopes and the Moon-forming giant impact. Science 294, 345-348.

Williams, L.B., Ferrell, R.E., Hutcheon, I., Bakel, A.J., Walsh, M.M., Krouse, H.R., 1995. Nitrogen isotope geochemistry of organic matter and minerals during diagenesis and hydrocarbon migration. Geochimica et Cosmochimica Acta 59, 765-779.

Winter, J.D., 2001. An introduction to igneous and metamorphic petrology. volume 697. Prentice Hall New Jersey.

Wlotzka, F., 1972. Handbook of Geochemistry. volume II. Springer-Verlag.

Workman, R.K., Hart, S.R., 2005. Major and trace element composition of the depleted MORB mantle (DMM). Earth and Planetary Science Letters 231, 53-72.

Yamaguchi, K., 2002. Geochemistry of Archean-Paleoproterozoic black shales: The early evolution of the atmosphere, oceans, and biosphere. Ph.D. thesis. The Pennsylvania State University.

Yokochi, R., Marty, B., 2006. Fast chemical and isotopic exchange of nitrogen during reaction with hot molybdenum. Geochemistry, Geophysics, Geosystems 7, 1-6.

Yokochi, R., Marty, B., Chazot, G., Burnard, P., 2009. Nitrogen in peridotite xenoliths: Lithophile behavior and magmatic isotope fractionation. Geochimica et Cosmochimica Acta 73, 4843-4861.

Yui, T.F., Kao, S.J., Wu, T.W., 2009. Nitrogen and N-isotope variation during low-grade metamorphism of the Taiwan mountain belt. Geochemical Journal 43, 15-27.

von Zahn, U., Kumar, S., Niemann, H., Prinn, R., 1983. Venus. volume 1. University of Arizona Press.

Zhang, Y., Yin, Q.Z., 2012. Carbon and other light element contents in the Earth's core based on firstprinciples molecular dynamics. Proceedings of the National Academy of Sciences 109, 19579-19583. 